\author{
Universidade de São Paulo \\ Faculdade de Filosofia, Letras e Ciências Humanas \\ Departamento de Ciência Política
}

\author{
MAIRA RODRIGUES
}

Mudanças na segregação espacial em Campinas e influência sobre as redes sociais de pobres urbanos 


\title{
MAIRA RODRIGUES
}

\section{Mudanças na segregação espacial em Campinas e influência sobre as redes sociais de pobres urbanos}

\author{
Dissertação apresentada ao Departamento \\ de Ciência Política da Faculdade de \\ Filosofia e Ciências Humanas da \\ Universidade de São Paulo, para obtenção \\ do título de mestre em Ciência Política. \\ Orientador: Prof. Dr. Eduardo César Leão \\ Marques
}

São Paulo

2008 


\section{FOLHA DE APROVAÇÃO}

\section{Maira Rodrigues}

Mudanças na segregação espacial em Campinas e influência sobre as redes de pobres urbanos.

Dissertação apresentada ao Departamento de Ciência Política da Faculdade de Filosofia e Ciências Humanas da Universidade de São Paulo, para obtenção do título de mestre em Ciência Política.

Este exemplar corresponde à redação final da dissertação defendida e aprovada pela Comissão Julgadora em 10/02/2009.

Banca examinadora

Prof. Dr. (orientador) Eduardo César Leão Marques

Prof. Dr. (titular interno) Adrian Gurza Lavalle

Prof. Dr. (titular externo) José Marcos Pinto da Cunha 
Dedico este trabalho à minha rede.

Em especial para minha avó Alex,

que sempre foi um exemplo de alegria para mim. 


\section{AGRADECIMENTOS}

Gostaria de poder agradecer a toda minha rede de amigos, colegas e familiares que muito colaboraram na elaboração desse trabalho.

Primeiramente agradeço ao meu orientador, Eduardo César Marques, que sempre me apoiou durante o desenvolvimento dessa pesquisa. Também foi fonte de inspiração não só teórica, mas também como exemplo de atenção, dedicação e principalmente curiosidade intelectual.

Agradeço também aos professores que participaram da minha banca de qualificação, Adrian Gurza Lavalle e Marta Arretche. As indicações que fizeram e questões colocadas na banca contribuíram muito para melhor desenvolvimento e conclusão desse trabalho. Agradeço ainda ao professor José Marcos Pinto da Cunha pelos comentários e dedicada argüição na banca de defesa dessa dissertação.

Também devo agradecimentos à Capes e à Fapesp pela concessão de bolsa de mestrado, apoio financeiro que favoreceu minha dedicação a essa pesquisa.

Sou muito grata também a todos os funcionários do Departamento de Ciência Política da USP, em especial à Vivian, Raimunda e Leonardo. Pessoas maravilhosas que sempre estiveram prontas para ajudar em todo tipo de tarefa necessária ao desenvolvimento do mestrado.

Sem dúvida tenho muito a agradecer para as pessoas que se dispuseram a participar da pesquisa dando entrevistas. Geralmente fui muito bem acolhida pelos moradores da Vila Castelo Branco e agradeço essa recepção e confiança. A participação dessas pessoas foi crucial para todo o trabalho e guardo seus nomes com muito carinho, apesar de não torná-los públicos a fim de preservar suas identidades. O pessoal do Progen e do Posto de Saúde Integração foram também muito importantes na localização de pessoas para as entrevistas e com informações sobre o bairro de modo geral.

Ainda é preciso agradecer as instituições que disponibilizaram seus acervos para consultas. Tanto os funcionários da Cohab-Campinas, quanto os do Centro de Memória da Unicamp - CMU foram muito solícitos em todas as ocasiões. O Núcleo de Estudos de População - NEPO, além de ser local certo de consultas a materiais bibliográficos e dados sobre Campinas, também foi onde encontrei apoio de amigos como Cláudia Gomes de Siqueira e Marcelo Tavares. Ainda, tive a oportunidade de contar com o 
auxílio prestado por Alberto Augusto Eichman Jakob no tratamento dos dados censitários para o bairro estudado.

Agradeço também aos colegas da minha turma de mestrado que se tornaram meus amigos e fonte de apoio nos momentos difíceis e também alegres da pósgraduação: Carlos Eduardo Noronha Roesler, Lara Mesquita Ramos, Nara de Carvalho Pavão e San Romanelli Assumpção.

Rafael Barros Soares foi grande companheiro na partilha de dúvidas e de descobertas sobre a análise de redes sociais. Aprendi muito com ele e espero poder ter ajudado em alguns momentos também.

Sou grata também a Rafael Cortez que se tornou grande amigo e sempre me apoiou e aconselhou em vários momentos decisivos.

Agradeço a Adele Mara Godoy, colega do mestrado que se tornou uma amiga muito querida e com inúmeras afinidades. Adele junto com Cláudia Marconi e Liliam Cavalhieri são minhas vizinhas, amigas e colegas de estudo que me acolheram tantas vezes em sua casa que também compõe parte da minha família paulistana.

Ao pessoal do grupo de estudo sobre Segregação, Pobreza e Redes Sociais do Centro de Estudos da Metrópole - CEM/CEBRAP. Principalmente a Renata Bichir, Encá Moya Recio, Thaíz Pavez, Gabriela Lotta, Igor Pantoja Alves e Miranda Zoppi. O acompanhamento de seus trabalhos e as conversas que tivemos ajudaram muito a esclarecer várias das minhas dúvidas e também pude aprender muito sobre a condução de ótimas pesquisas. Agradeço ainda ao Igor pela ajuda na elaboração dos sociogramas, imprescindível para a realização desse trabalho. Mais um integrante do CEM/CEBRAP a quem devo agradecimentos é José Donizete Cazollato que me deu uma ajuda incrível na confecção dos mapas que apresento aqui.

Agradeço ainda a Francisco Barbosa de Macedo que me acompanhou em algumas entrevistas, suscitando milhares de dúvidas que me levaram a importantes reflexões sobre a condução das entrevistas e o tratamento dos dados coletados.

Entre os amigos agradeço todos aqueles que estão presentes na minha vida. Em especial reconheço as contribuições diretas de Fabio Yoiti Hirano para o desenvolvimento dessa dissertação, seja lendo os primeiros esboços, seja em dicas e conversas gerais. Muito obrigada.

Às meninas que moram comigo, Amanda Martins e Fernanda Lobo Caldeira por todo carinho, amizade e paciência. É ótimo compartilhar a casa com vocês. 
À minha família um agradecimento especial. Agradeço à minha mãe, Mara Silvia Sanches, pelo incentivo constante e modelo de inteligência e questionamento. Nossas conversas sempre ampliaram meu olhar sobre o mundo.

Ao meu pai, Carlos Eduardo Rodrigues Oliveira, por todas as oportunidades que me ajudou a alcançar e por sempre me lembrar da minha capacidade. À Sara e Tayra Rodrigues, minhas irmãs e amigas maravilhosas. Sei que sempre posso contar com vocês para tudo e isso é muito bom. Nossa amizade incondicional é uma das minhas principais fonte de forças.

Por fim, agradeço ao meu querido Carlos Roberto Filadelfo de Aquino. Foi fundamental por todo apoio, paciência e incentivo incessante para a realização desse trabalho. Além disso, é meu companheiro constante para diversas empreitadas da vida. 


\section{RESUMO}

A preocupação central deste trabalho é explorar como a mudança na segregação espacial pode ter influência sobre as redes sociais de moradores de um bairro popular da cidade de Campinas. O referencial empírico é o bairro Vila Castelo Branco, construído pela Cohab - Campinas em 1967 para população de baixa renda. Esse caso ilustra um processo de incorporação de um bairro segregado espacialmente e a pesquisa desenvolvida aqui foi o estudo das alterações que essa mudança espacial imprimiu sobre as redes sociais das pessoas que aí vivem. Tal proposta se insere no debate sobre as desigualdades de acesso a bens materiais e imateriais que os indivíduos encontram devido a dinâmicas espaciais e também relacionais. A análise dos dados empíricos lança luz a interpretações correntes na literatura sobre as possibilidades de ampliação e diversificação de contatos sociais a partir da proximidade espacial. Para realização da proposta de trabalho, foram construídas as redes sociais dos moradores entrevistados em dois períodos correspondentes à segregação espacial e as condições atuais do bairro.

Palavras-chave: Segregação urbana; redes sociais; pobreza; Campinas; Vila Castelo Branco. 


\begin{abstract}
The main concern of this dissertation is to explore the way that a change in the spatial segregation can influence the social networks of inhabitants in a popular district in the city of Campinas. The empiric reference is Vila Castelo Branco, a district built by Cohab - Campinas in 1967 for the low-income population. This case illustrates a process of incorporation of a spatially segregated district and the research developed was the study of the transformation that this spatial change caused to the social network of the people living there. Such proposal is inserted in the debate on the inequality in the access to material and immaterial wealth found by individuals and caused by spatial and relational dynamics. The analysis of the empiric data enlightens the current interpretations about the possibilities of amplification and diversification of social contact from spatial proximity. For the realization of the work proposal, inhabitants' social networks were built in two periods, one corresponding to the spatial segregation and the other to the current conditions of the district.
\end{abstract}

Key words: Urban segregation; social networks; poverty; Campinas; Vila Castelo Branco. 


\section{SUMÁRIO}

Introdução

pág. 13

Capítulo 1 - Abordagem teórica de segregação espacial e redes sociais

1.1. Entendendo a segregação espacial

pág. 18

1.1.1. Segregação e periferia

pág. 24

1.1.2. Mudanças na expressão do fenômeno

pág. 28

1.2. Abordagem de redes sociais: possibilidades teóricas e metodológicas

1.2.1 Dinâmicas das redes

pág. 31

1.2.2. Pensando redes e espaço

pág. 34

1.2.3. Algumas definições de pesquisa das redes sociais

pág. 36

pág. 40

Capítulo 2 - Redes na Vila Castelo Branco

2.1. Campinas e seu desenvolvimento urbano: observando a segregação na cidade

pág. 46

2.1.1. Primeiros anos do bairro pág. 49

2.1.2. Novas periferias em Campinas pág. 53

2.1.3. O bairro hoje pág. 58

2.2. Quem são os entrevistados e dados gerais sobre o bairro pág. 61

2.3. Redes no bairro pág. 66

2.4. Procedimentos e definições de pesquisa pág. 71

Capítulo 3 - Considerações de dois períodos: retratos da mudança reconstruída hoje

3.1. Retratos da mudança pág. 76

3.2. Redes em cada período e sua dinâmica pág. 77

3.2.1. Tamanho pág. 78

3.2.2. Homofilia de sexo pág. 90 
3.2.4. Diversidade da Sociabilidade pág. 95

3.2.5. Esferas de sociabilidade e localismo pág. 102 3.3. Síntese dos resultados pág. 104

Considerações finais pág.108

Referências Bibliográficas

pág. 111 


\section{LISTA DE MAPAS, TABELAS E FIGURAS}

Mapa 1 - Localização da Vila Castelo Branco no Município de Campinas.

pág. 55

Mapa 2 - Setores censitários correspondentes a Vila Castelo Branco e bairros vizinhos.

pág. 55

Mapa 3 - Imagem de satélite com os limites da Vila Castelo Branco.

pág. 56

Mapa 4 - Porcentagem de chefes de domicílio com renda mensal maior que 10 salários mínimos. Região Metropolitana de Campinas, 1991 e 2000.

pág. 57

Tabela 1 - Composição etária da população da Vila Castelo Branco

pág. 65

Tabela 2 - Freqüência das esferas entre as redes dos entrevistados no $t 1$ pág. 96

Tabela 3 - Perfis de sociabilidade no t1 pág. 97

Tabela 4 - Freqüência das esferas entre as redes dos entrevistados no t2 pág. 98

Tabela 5 - Perfis de sociabilidade no $\mathrm{t} 2$ pág. 99

Tabela 6 - Esferas em t1 e t2 em ordem decrescente de freqüência entre os entrevistados.

pág. 100

Tabela 7 - Comparação da ocorrência das esferas entre os períodos pág. 100

Tabela 8 - Comparação dos perfis de sociabilidade entre os dois períodos pág.102

Tabela 9 - Comparação das médias entre os dois períodos

pág. 105

Figura 1 - Sociograma da entrevistada 20 no 11 pág. 79

Figura 2 - Sociograma da entrevistada 5 no 11 pág. 80

Figura 3 - Sociograma da entrevistada 27 no $\mathrm{t} 1$ e no $\mathrm{t} 2$ pág. 84

Figura 4 - Sociograma da entrevistada 21 no t1 pág. 85

Figura 5 - Sociograma da entrevistada 21 no $t 2$ pág. 85

Figura 6 - Sociograma da entrevistada 19 no t1 pág. 87

Figura 7 - Sociograma da entrevistada 19 no t2 pág. 87

Figura 8 - Sociograma da entrevistada 11 no t2 pág. 91 


\section{INTRODUÇÃO}

A preocupação central deste trabalho é explorar como a mudança espacial pode ter influência sobre as redes sociais de moradores de um bairro popular da cidade de Campinas, no estado de São Paulo. O caso da Vila Castelo Branco ilustra um processo de incorporação de um bairro segregado espacialmente e a proposta desenvolvida aqui foi o estudo das alterações que esse processo imprimiu sobre as redes de relações sociais das pessoas que aí vivem.

Considerando dois momentos referentes primeiramente à segregação espacial inicial e posteriormente a integração do bairro à cidade, o estudo focou sobre as redes sociais dos moradores que passaram pelo processo de alteração na sua condição espacial. De modo geral, as redes sociais dos indivíduos estudados eram menores, mais locais e menos variadas em termos de sociabilidade no primeiro período, corroborando as hipóteses da literatura que trata do tema da segregação. O enfoque dado aos efeitos da integração espacial sobre essas redes comparativamente coloca em evidência os resultados da separação e ainda reforçam as vantagens relacionais que a proximidade espacial pode trazer em termos sociais.

Segregação e redes sociais são temas com importante reflexo sobre a pobreza urbana. Tanto um quanto o outro podem significar restrição ou acesso a bens e serviços, significados esses ainda mais decisivos quando estamos falando de pessoas com importantes restrições sociais que podem ser agravadas por suas baixas condições econômicas.

Como veremos mais adiante, a segregação espacial é um dos fenômenos que interfere nas possibilidades de acesso a infra-estrutura e serviços urbanos, bem como a outras condições de vida - como mercado de trabalho, políticas públicas e mesmo bens imateriais. Nos estudos sobre a pobreza, principalmente a concentrada espacialmente, um dos quesitos que são considerados como passíveis de suprir essas carências são as redes sociais. Isto porque é através delas que os indivíduos se inserem em círculos sociais mais amplos e diversificados que podem agregar referências que facilitam a aquisição de determinados bens.

O levantamento de dados empíricos realizado lança luz a essas interpretações correntes na literatura sobre as possibilidades de ampliação e diversificação de contatos sociais a partir da proximidade espacial. 
A Vila Castelo Branco foi construída pela Cohab - Campinas em 1967 como parte do projeto piloto de construção de bairros populares pelo Banco Nacional de Habitação $-\mathrm{BNH}^{1}$. De acordo com as orientações do mercado imobiliário e da política habitacional da época, o bairro se localizou distante da mancha urbana de Campinas, com várias carências de infra-estrutura e com concentração de população pobre. Essa descrição das condições iniciais do bairro corresponde à caracterização da segregação espacial utilizada como referência nesse estudo.

A escolha da área de estudo levou em consideração tanto essas características, como o fato de ser um bairro construído por uma política pública de habitação, entendendo que sua localização segregada foi determinada através de um processo institucional de decisão. De modo que a segregação de um bairro construído através de política pública destaca a segregação como orientação política evidente e grave, se pensarmos que a oferta de moradia para as classes mais pobres se enquadra em mecanismos que acentuam as desigualdades sociais.

Por definição, a segregação espacial é um fenômeno de restrição de contatos sociais entre pessoas ou grupos com alguma característica que as distingue entre si. De modo que a concentração de população semelhante em determinado aspecto em espaço delimitado, seja pela distância territorial, seja por muros, tende a impor constrangimento às possibilidades relacionais.

A segregação em si pode ter efeitos diversos sobre as relações sociais, não sendo necessariamente negativos. Um bairro de classe alta, segundo Bourdieu (2003), tem um efeito de clube entre as pessoas que o habitam e freqüentam, consagrando simbolicamente cada um que dele faz parte. Do mesmo modo, a homogeneidade social da pobreza pode colaborar na criação de relações de sociabilidade e solidariedade internas ao grupo. Relações essas que podem inclusive ter efeitos diretos na redução de despesas pelo compartilhamento de bens e ajudas prestadas, diminuindo ou mesmo evitando gastos econômicos (Almeida e D'Andrea, 2005; Zaluar, 1985).

De toda forma, a segregação espacial se configura como um mecanismo que tende a aumentar a homogeneidade dos padrões de vínculos dos indivíduos, representando uma barreira a oportunidades e contatos devido aos custos para sua transposição. A limitação do mundo social dos indivíduos pela segregação pode ter

\footnotetext{
${ }^{1}$ O Banco Nacional de Habitação foi criado em 1964 e tinha três políticas distintas com três subdivisões internas para atender populações de diferentes faixas de renda. As Companhias Habitacionais - Cohabs eram seus órgãos para a população de mais baixa renda (de até três salários mínimos mensais) e formavam parcerias com as prefeituras municipais como estratégia de atuação. Cf. Gonçalves, 2002.
} 
impacto mais negativo entre os pobres devido ao chamado mecanismo de "economia dos vínculos" (Marques, 2007), segundo o qual os custos de criação e manutenção dos vínculos restringiriam o tamanho, a diversidade das esferas de sociabilidade e a espacialização das relações entre os indivíduos mais pobres.

Além da possibilidade de restrição relacional, a segregação espacial pode ter um efeito de perpetuação das condições de sua população, devido ao mecanismo de acúmulo de bens e carências pelo espaço que funciona como constrangimento a mudanças (Kowarick, 1977). A desigualdade social refletida em desigualdade espacial fornece assim acessos desiguais a bens materiais através de serviços ou mercado de trabalho e também a bens imateriais, como repertórios ou formas de viver (Marques, 2007).

Dessa forma, a relevância da dimensão espacial pode ser melhor apreendida pelo reconhecimento da complexidade existente entre a estrutura espacial e a relacional, tomando "o espaço como parte componente da sociedade, e não simples manifestação externa da mesma", como afirma Bichir (2006, p. 23). Nessa mesma linha, Marcuse (2004) sublinha que o espaço não tem um papel constante, é continuamente criado socialmente de forma que a direção de influência é recíproca e suas condições também influenciam as relações sociais.

Considerando a influência que o espaço pode exercer sobre as redes sociais, o caso de estudo permite verificar essa dinâmica devido às alterações que o bairro sofreu. Apesar da segregação inicial, com o passar dos anos outros bairros surgiram ao redor da Vila Castelo Branco e a cidade cresceu. O bairro acabou sendo integrado à mancha urbana e teve muitos serviços e infra-estrutura urbana implantados, de modo que não podemos mais considerá-lo segregado como inicialmente.

Tais mudanças permitem a comparação entre duas composições espaciais distintas dadas para a mesma população, sendo este mais um motivo que torna a Vila Castelo Branco interessante para a investigação. O que se espera é que a descrição das mudanças das redes pela incidência da alteração espacial, observada analiticamente em dois períodos, permita aprofundar o conhecimento sobre a relação entre a mudança espacial e as redes.

Em qualquer contexto, as relações sociais são responsáveis pela distribuição de diversos recursos, seja através de relações de trabalho, ajuda, amizade, entre outros. Sendo as redes um meio de fluidez de recursos e, portanto, de impacto sobre a pobreza, o entendimento de seu funcionamento em relação ao espaço combina dois mecanismos 
de acesso e restrição com importantes influências sobre a manutenção ou alteração de situações de desigualdade social.

Com esse objetivo, o caso estudado permitiu a consideração de dois períodos de tempo que se referem ao processo de passagem da Vila Castelo Branco da condição de segregada a não segregada ou integrada ${ }^{2}$. Esses períodos foram estabelecidos analiticamente com base em documentos sobre o bairro (Gonçalves, 2002; Antunes, 2006 e arquivos da Cohab - Campinas e do Centro de Memória da Unicamp - CMU), em entrevistas realizadas com moradores, bem como na própria literatura sobre o histórico urbano de Campinas e seus processos de organização espacial. De modo que desde a construção da Vila Castelo Branco - no final da década de 1960 - até meados dos anos 1980 constitui o primeiro período e a partir daí até hoje temos o segundo período.

É importante assinalar que a literatura que trata do tema da segregação espacial geralmente não aborda a mudança ou processos de integração de bairros ou quaisquer espaços às cidades. Um dos autores que tenta captar esse processo é Marcuse (2004), usando o termo "dessegregação", porém, para casos de eliminação de barreiras de residentes de um gueto, denotando uma situação específica de processo de integração e distinta da considerada aqui. De modo geral, a análise da segregação espacial foca-se em uma situação estanque e não foram encontradas referências no sentido para o qual aponta o presente trabalho.

Portanto, o enfoque na integração de um espaço segregado se reveste de um desafio e aponta uma lacuna pouco explorada pelos estudos e que merece atenção. $\mathrm{O}$ objetivo não é preencher em absoluto esse espaço, mas indicar possíveis encaminhamentos a partir da observação empírica aqui desenvolvida e delimitada pela proposta dessa pesquisa.

Esta dissertação é composta por três capítulos além desta introdução e das considerações finais. O primeiro capítulo se detém sobre a abordagem teórica de segregação espacial e redes sociais. Primeiramente definindo como segregação e redes sociais são entendidas no âmbito desse trabalho e quais são as relações que podem ser estabelecidas entre essas duas dimensões. Por fim, são apresentadas algumas definições de pesquisas relacionadas à análise de redes sociais.

\footnotetext{
${ }^{2}$ A definição do conceito de segregação será detalhada no capítulo 1 dessa dissertação.
} 
O segundo capítulo se concentra sobre o contexto de estudo, iniciando com um panorama do desenvolvimento urbano de Campinas e como a segregação espacial tem sido observada nessa cidade. A Vila Castelo Branco também é situada no quadro mais amplo da cidade e suas características que interessam ao estudo são exploradas para conhecimento do contexto de investigação. Em seguida são apresentados os sujeitos da pesquisa, entrevistados entre os moradores do bairro e dados gerais são elencados para comparação com as informações de perfis desses entrevistados. Esse capítulo termina com uma breve exploração sobre os elementos comuns à redes no bairro e com a descrição dos procedimentos de elaboração das redes de seus moradores.

O terceiro e último capítulo traz as análises dos componentes das redes como tamanho, homofilia de sexo, localismo dos nós, diversidade das esferas de sociabilidade e a relação entre essas esferas com o localismo. A análise comparativa desses elementos nos dois períodos delimitados é o objetivo principal desse trabalho e trouxe resultados interessantes de como a mudança espacial incidiu sobre as redes sociais dos moradores da Vila Castelo Branco.

O balanço desses resultados em relação à questão chave de pesquisa compõe a última parte dessa dissertação. Chegamos às considerações finais da investigação com uma breve análise do impacto das condições espaciais sobre as relações desenvolvidas principalmente no interior do bairro a partir dos resultados de composição das redes. 


\section{CAP. 1 - ABORDAGEM TEÓRICA DE SEGREGAÇÃO ESPACIAL E REDES SOCIAIS}

\subsection{Entendendo a segregação espacial}

No estudo sobre a história da Vila Castelo Branco realizado durante pesquisa de iniciação científica ${ }^{3}$, um dos elementos presentes em todas as respostas dos entrevistados sobre seus primeiros anos é a questão da segregação espacial. Foram citadas principalmente as dificuldades que a distância do bairro ao centro da cidade e de outros bairros impunha aos moradores, isto é, dificuldade no acesso ao mercado de trabalho e à serviços públicos e privados concentrados na região central da cidade. A falta de infra-estrutura urbana associada à distância compunha um cenário que combinado com a baixa renda das pessoas residentes no bairro dificultavam ainda mais as condições de vida dessa população.

Para entendermos como esses elementos caracterizam a segregação espacial é preciso aprofundar em sua definição já que existem formas de segregação mais excludentes que outras e variações específicas de conteúdo dadas pelos contextos de estudo. Os autores que tratam do tema da segregação a adjetivam de diversas formas, como segregação espacial, territorial, residencial, racial, econômica, social, entre outras. No entanto, de modo geral, a segregação é tida como o fenômeno de concentração de população homogênea em determinada característica, que pode se econômica, étnica, religiosa, entre outras, em determinado espaço com algum nível de restrição social causada por essa concentração e separação (Almeida e D'Andrea, 2005; Bichir, 2006; Caldeira, 1997 e 2000; Cunha et al., 2006; Kaztman, 2001; Marques, 2005; Sabatini, Cáceres e Cedra, 2004; Sabatini, 2004; Torres, 2004).

Neste trabalho a utilização do termo segregação espacial deve-se ao fato de considerá-lo mais abrangente e adequado para o caso em questão, onde a separação espacial tem relevância fundamental para a demarcação da situação de segregação.

Vale ressaltar que a noção de homogeneidade no espaço deve-se a concentrações relativas de certas características, uma vez que não se pode pensar que o tecido urbano

\footnotetext{
3 "História Oral: prática de pesquisa-ação para levantamento de memória de bairro". Essa pesquisa foi realizada com o apoio da FAPESP e integrada ao projeto "Memória, Qualidade de Vida e Cidadania: História dos Bairros Populares de Campinas", do Centro de Memória da Unicamp - CMU
} 
seja homogêneo estritamente falando, mesmo considerando pequenas porções, como lembra Cunha et al. (2006).

Apesar da convergência dos autores que trabalham com o tema da segregação nas grandes cidades brasileiras e mesmo outras cidades latino-americanas a definição geralmente fica subjacente à teoria ou metodologia utilizada, como ressalta Lago (s/d). Isto é, a definição da segregação adquire certos contornos de acordo com o panorama de fundo do pesquisador.

Sabatini, Cáceres e Cedra (2004), por exemplo, denominam segregação objetiva a tendência à concentração de um grupo espacialmente e a conformação de áreas ou bairros socialmente homogêneos. No entanto, ressaltam uma terceira dimensão da segregação que vão chamar de segregação subjetiva, isto é, a percepção que os indivíduos têm das dimensões anteriores. Essa segregação subjetiva pode ser sentida muitas vezes pela estigmatização e marginalização de grupos sociais menos favorecidos, fenômeno mais presente em situações de pobreza extremada.

No entanto, a estigmatização e marginalização podem ser evidentes também em situações onde a delimitação da concentração espacial não ocorre devido a distância espacial entre os grupos sociais. Partindo dessa perspectiva, Caldeira (2000) explora situações de convivência espacial próxima entre ricos e pobres, mas com demarcações físicas bem visíveis através da construção de muros, como em enclaves e condomínios fechados.

Esse tipo de segregação, denominada de segregação social, tem repercussão distinta entre os grupos. Isto porque apesar de reforçar a distância social pelo estigma, a proximidade física pode oferecer oportunidades para os mais pobres significando melhores condições relativas. Almeida e D'Andrea (2005) em estudo sobre a favela de Paraisópolis $^{4}$ em São Paulo revelam que mesmo com relativa segregação social há possibilidades de acesso a algum consumo, assistência social e ocupação profissional, ainda que precários, limitados e informais. Segundo esses autores, o fato de estar próximo coloca a questão da pobreza para os vizinhos ricos do Morumbi, ao mesmo tempo, que as redes articuladas no interior de Paraisópolis se beneficiam da estrutura da localidade. E o próprio fato de morar nessa favela e não em outra, significa motivo para atração de recursos para seus moradores.

\footnotetext{
${ }^{4}$ Paraisópolis é um caso diferenciado de segregação em São Paulo, por se localizar no entorno de condomínios de classe média e alta do bairro do Morumbi. Como dizem os autores a "favela de Paraisópolis é um contexto de pobreza geograficamente circunscrito por uma região de altíssima renda" (Almeida e D'Andrea, 2005, p. 195).
} 
A conclusão que se pode tirar desse estudo é a diferença do local onde se é pobre, pois a moradia em Paraisópolis oferece uma ascensão relativa para os indivíduos em relação a locais mais distantes. Esse caso de segregação, ainda que com características negativas para a população dessa favela, ilustra como a localização próxima a áreas bem providas pode fornecer vantagens em relação à bairros mais isolados. De maneira complementar, esse estudo também ajuda a evidenciar como a distância e o isolamento podem ser agravantes das condições de segregação dos pobres urbanos.

Ainda, segundo Kaztman (2001), o isolamento pode se tornar um obstáculo importante para acumular ativos necessários para o indivíduo deixar de ser pobre ou ao menos alcançar melhores condições de vida. O que faz com que "a pobreza isolada se constitua em um caso paradigmático da exclusão social” (Kaztman, 2001, p. 173, tradução minha).

Pode-se observar nos estudos citados que há uma diversidade de formas de se entender a segregação, mesmo que existindo certa convergência na sua compreensão como concentração espacial de população homogênea. Lago (s/d) em sua avaliação de trabalhos sobre o assunto, chama a atenção para a abrangência com que o termo vem sendo utilizado nos diversos estudos. Afirma que em alguns casos apesar de não ser utilizado o termo segregação, os trabalhos tratam do fenômeno através do recorte de favelas, do tema da exclusão social e da desigualdade de acesso à infra-estrutura.

De fato, o termo abarca situações sociais que podem ser muito diversas entre si, desde apartação ostensiva de grupos sociais como no regime de apartheid na África do Sul e os guetos negros norte-americanos, até casos mais tênues do ponto de vista de interdição social, como os geralmente encontrados em alguns contextos contemporâneos e nas cidades brasileiras ${ }^{5}$.

Isso acontece muitas vezes porque a segregação espacial se relaciona com uma diversidade de fenômenos que apresentam resultados diversos, ainda que geralmente desembocando em formas de distinção entre grupos sociais que reforçam as desigualdades presentes na sociedade. A seguir, são apresentados três desses processos correlacionados à segregação.

Como já citado acima, um dos processos mais extremados de segregação é a apartação e isolamento de grupos em guetos e cidadelas, quando existem barreiras

\footnotetext{
${ }^{5}$ Ver mais a esse respeito em Kowarick (2002).
} 
físicas e/ou legais nítidas para entrada ou saída em certos espaços - como no regime de apartheid africano, por exemplo. Nas palavras de Marcuse (2004) trata-se de uma alocação involuntária do espaço que é indesejável em uma sociedade democrática ${ }^{6}$. Isso porque, no limite, esse tipo de apartação dificulta ou mesmo impede o contato entre a diversidade dos indivíduos e a comunicação aberta entre eles, requisitos fundamentais desse tipo de sociedade.

No contexto brasileiro, apesar de não constarem disposições claras de limites a circulação, algumas restrições vêm sendo implantadas com o aumento da construção de condomínios fechados e outros tipos de enclaves. A requisição de identificação e possível impedimento da circulação de pessoas nesses espaços são formas de consolidar distâncias sociais, corroborando a evitação e separação entre ricos e pobres e que, segundo Caldeira (1997 e 2000), vem sendo justificada pela fala do crime ${ }^{7}$.

Entretanto, é difícil assumir que esse caso trate propriamente de processos de restrição social em sentido definitivo da mesma forma que são os guetos. Mesmo que as limitações que essas situações possam colocar para os contatos entre grupos sociais, reporte diretamente ao que se entende por segregação, ainda existe a possibilidade do contato.

Em sentido semelhante, a moradia muito distante também configura um tipo de isolamento social, devido ao impedimento da mobilidade causado pelo peso dos custos dos meios de transporte para orçamentos de baixa renda. No entanto, Marques (2005) alerta para a dificuldade da operacionalização dessa idéia de segregação, uma vez que não existem parâmetros estabelecidos sobre o que seriam deslocamentos impeditivos e mesmo o que significam distâncias grandes.

Apesar disso, a distância constitui um elemento importante para a definição de segregação muito utilizado na bibliografia em geral e de fundamental importância para o presente trabalho, por ser justamente um dos aspectos mais nítidos da mudança espacial pela qual passa o bairro estudado. Por isso essa dimensão será tratada

\footnotetext{
${ }^{6}$ Marcuse (2004) desenvolve distinções precisas de tipos de processos de segregação e seu significado em termos espaciais. Essa tipificação não será explorada aqui por fugir ao escopo do trabalho desenvolvido. Para mais detalhes ver obra citada.

${ }^{7}$ Segundo essa autora, o crime oferece uma linguagem para expressar medidas de combate à violência, mas que tende a ampliá-la pela criação de estereótipos e proliferação de práticas de segregação. Para Caldeira (2000), a fala do crime é um mecanismo que permite a construção de fronteiras sociais, e "uma das maneiras de fazer isso é elaborar preconceitos e marcas de distinção. As depredações mais explícitas e veementes aparecem quando a proximidade e a ameaça da mistura aumentam. (...) Em outras palavras, a proximidade leva ao refinamento das separações para que a percepção de diferença seja mantida. $\mathrm{O}$ contexto do aumento da violência e o medo do crime intensifica incertezas mas ao mesmo tempo fornece um contexto em que as depreciações e separações podem proliferar sem censura". (Caldeira, 2000, p. 75).
} 
conjuntamente com outros processos correlacionados à segregação que serão explorados a seguir.

Além do sentido de apartação, um segundo efeito definidor da segregação é a desigualdade de acesso de maneira ampla. Isto é, os espaços segregados são locais em geral menos beneficiados por políticas de infra-estrutura urbana, bem como de serviços e atendimento público (por exemplo, postos de saúde e hospitais) e mesmo no setor privado (como comércio). Dessa maneira, a ausência desses bens em locais segregados e a distância para usufruí-los onde eles estão presentes somam-se como fatores que restringem o acesso a eles.

O último sentido considerado aqui trata justamente de outra característica importante para o caso empírico em questão que é a concentração ou homogeneidade interna da população em relação à heterogeneidade externa na distribuição dos grupos no espaço. Como defende Torres (2004), a segregação deve ser tomada como fenômeno relacional, ou seja, "só existe segregação de um grupo quando outro grupo se segrega ou é segregado" (Torres, 2004, p. 3). Bichir (2006) também realça essa dinâmica entre os grupos sociais e que a homogeneidade interna é percebida em comparação com a heterogeneidade externa, de forma que é nesse componente relacional que podemos verificar o grau de isolamento de determinado grupo em relação a outro e as implicações dessa segregação.

Em relação à homogeneidade do grupo segregado, esta pode dizer respeito a diversas características econômicas, étnicas, religiosas, entre outras, como foi dito acima. Portanto, a caracterização do fenômeno requer rigorosa conceituação para pensar sua propriedade para o contexto em questão.

$\mathrm{Na}$ definição do fenômeno, a constatação sobre qual a característica distintiva do grupo concentrado se dá a partir da consideração das principais clivagens presentes em cada contexto. Como aponta Préteceille (2004, p. 20):

A escolha das categorias pertinentes para a análise da segregação corresponde em larga medida às categorias propaladas na enunciação pública do problema, resultado do processo sócio-político específico a cada país de construção histórica das representações das questões social e urbana.

No contexto de estudo, a baixa renda aparece como categoria distintiva da população segregada de forma evidente e complexa. Por um lado, a falta de moradia 
para população de baixa renda se consolida como questão a ser resolvida por política pública resultando no desenvolvimento de elaborada engenharia governamental e financeira que constrói conjuntos habitacionais como a Vila Castelo Branco, utilizando justamente como critério de seleção a renda. No entanto, a política é implantada a partir do paradigma da segregação, isto é, resolve-se a carência habitacional estabelecendo a diferenciação social através do espaço pela concentração dessa população e com conseqüências sobre a perpetuação da pobreza.

Torres (2004), em estudo sobre a segregação residencial e políticas públicas em São Paulo, destacou elementos que evidenciam como a segregação pode contribuir para o aumento e/ou perpetuação da pobreza. Dentre os elementos considerados pelo autor encontramos a distância e a carência de infra-estrutura e serviços, ambos fatores existentes na Vila Castelo Branco e citados por seus moradores como os principais problemas enfrentados no início do bairro.

Segundo Torres (2004), a distância entre a moradia e a região central da cidade se conecta as dificuldades de conseguir emprego, devido à rara existência deste em locais de moradia de população de baixa renda e também pelos efeitos que essa distância tem sobre a obtenção de informações sobre postos de trabalho ${ }^{8}$.

Outro fator do efeito da segregação sobre a pobreza diz respeito às condições urbanas do local de moradia, que dariam pior acesso a serviços públicos de vários tipos, serviços esses que poderiam contribuir na minimização dos efeitos da pobreza para a população. O efeito de perpetuação das condições da população residente em um espaço segregado deve-se, assim, a um mecanismo de concentração e acúmulo de bens e carências em distintos espaços urbanos.

Segundo Kowarick (1977), essa concentração e acúmulo seguem padrões correspondentes as desigualdades socioeconômicas encontradas na sociedade, tornando assim, o espaço expressão dessas relações sociais desiguais. De forma que, como conseqüência das desigualdades sociais, os espaços são hierarquizados e segregados fornecendo acessos desiguais a bens materiais através de serviços ou mercado de

\footnotetext{
${ }^{8}$ Segundo o princípio de interação homofilica estudado por Granovetter (1973), os vínculos fracos seriam os estabelecidos com pessoas com as quais temos contatos menos freqüentes e que possuem características menos homogêneas, contribuindo justamente com informações que estão disponíveis em diferentes meios sociais. Dessa forma, um dos efeitos da diversidade da rede seria justamente aumentar a possibilidade de existência desse tipo de interação, ampliando o contato com repertórios e informações que não existem em locais segregados, facilitando a obtenção de empregos, por exemplo. Os efeitos desse princípio sobre as redes serão discutidos mais detidamente na seção sobre a abordagem de redes desse mesmo capítulo.
} 
trabalho e também a bens imateriais, como repertórios ou formas de viver (Marques, 2007).

Contudo, apesar dessas considerações sobre a conformação dos espaços a partir das relações sociais, é necessário sublinhar que a estruturação do espaço não antecede nem decorre do social, mas também o constitui. Assim, antes de tomarmos uma relação determinante de causa e efeito, é possível considerar esses dois níveis - espaço e relações sociais - como interdependentes (Arantes Neto, 2000). Dessa forma, a relevância da dimensão espacial pode ser melhor apreendida pelo reconhecimento da complexidade existente entre a estrutura espacial e a relacional, tomando "o espaço como parte componente da sociedade, e não simples manifestação externa da mesma", como afirma Bichir (2006, p 23).

É nesse sentido que mesmo reconhecendo o espaço como expressão de desigualdades sociais é possível entender que ele pode influenciar as redes sociais dos indivíduos, já que por definição, a segregação espacial é um fenômeno de restrição de contatos entre os indivíduos. É importante ressaltar aqui que a utilização da análise das redes sociais não tem como objetivo explicar a segregação, nem quaisquer padrões de organização espacial. Entende-se que as relações sociais influenciam o espaço, pois estas compõem um emaranhado de relações econômicas, culturais, lingüísticas, históricas e políticas, que podem se combinar de diversas maneiras na definição dos espaços.

A partir do que foi apresentado acima, pode-se circunscrever a definição que ancora esse estudo aos dois aspectos gerais da segregação, ou seja, espaço territorial separado fisicamente da cidade da qual ele pertence e que concentra determinada população considerada homogênea sobre algum aspecto. Essas seriam as características mais evidentes nos primeiros anos da Vila Castelo Branco, quando o bairro foi construído distante da mancha urbana e com concentração de população pobre.

Contudo, veremos que a segregação espacial desse bairro nos seus primeiros anos além de ser demarcada por esses aspectos, ainda é marcada por carências de infraestrutura e serviços. Essa combinação de condições se encaixa na caracterização de periferia corrente na bibliografia especializada no assunto durante os anos 1970 e 1980 . Dessa forma, é importante distinguir o que faz parte do processo de segregação espacial e o que compõe as chamadas periferias urbanas, principalmente quanto as características que remetem ao objeto de estudo empírico deste trabalho. 


\subsubsection{Segregação e periferia}

Uma das dificuldades para se entender a segregação reside no fato dela ser um fenômeno que conecta dimensões econômicas, culturais e políticas com dimensões espaciais da realidade social (Sabatini, 2004). Nesse sentido, o esforço de muitos estudiosos do assunto está em dissociar o fenômeno de outros processos sociais para entender o que estimula e o que é conseqüência da segregação.

Esse apontamento se mostra ainda mais relevante se considerarmos que até o final dos anos 1980 ocorria certa coincidência entre o processo de segregação espacial e as periferias urbanas. Marques e Bichir (2002) indicam como as periferias foram definidas com certo consenso na bibliografia dos anos 1970 e 1980 como áreas afastadas do núcleo urbano da cidade, espaços de condições de vida precárias, "espaços fora da ação estatal", com um "padrão espacial de carências e segregação social". Essa sobreposição produzia dificuldades analíticas de percepção das características próprias a cada fenômeno, além de estabelecer uma correlação imediata desses como espaços da pobreza urbana.

De acordo com Bichir (2006, p. 26), o tema da segregação

foi tradicionalmente abordado na literatura da sociologia urbana brasileira como conseqüência - não trivial - de outros processos, como os padrões de crescimento urbano nas grandes metrópoles, como resultante do processo de periferização que contribuiu para os deslocamentos das camadas populares para os locais mais distantes dos núcleos urbanos.

Essa concepção relacionava intimamente os processos de segregação com os processos de periferização do capitalismo ${ }^{9}$, contribuindo para essa abordagem conjunta de ambos os fenômenos.

Contudo, inúmeras mudanças ocorreram nas cidades e em suas periferias nas últimas décadas e reconsiderações teóricas se mostraram necessárias para abarcar essas especificidades e as novas realidades. Para entender essas mudanças, os estudos traçam alguns padrões predominantes de organização espacial das cidades brasileiras marcados em grande parte por dinâmicas de segregação espacial.

\footnotetext{
${ }^{9}$ As explicações predominantes na sociologia urbana brasileira dos anos 1960 e 1970 tinham forte inspiração marxista e entendiam o fenômeno urbano a partir da ótica do capitalismo periférico e dependente. Ver, por exemplo, Kowarick (1977 e 2000).
} 
Pode-se dizer que entre os anos 1940 a 1980, predominou o modelo da cidade chamado de centro-periferia ou radial-concêntrico. Esta definição considera o espaço urbano organizado em camadas circulares a partir de uma central que concentra diversos tipos de recursos e população rica. Riqueza essa que vai diminuindo de densidade até as bordas, onde se concentra população pobre e onde há carência de serviços e infraestrutura urbana precária (Caldeira, 2000; Rolnik, 1997). Essa dinâmica espacial é geralmente acompanhada de vazios demográficos destinados a especulação imobiliária.

Rolnik (1997) destaca como mudanças na legislação urbana ajudam a configurar esse padrão, a partir da oposição da regularização da área central e falta de regulamentação para áreas suburbanas e rurais, facilitando a ocupação dessas regiões pelos mais pobres que não conseguem se encaixar nos pré-requisitos do mercado imobiliário legal. Por vezes, além do mercado, mesmo políticas de infra-estrutura e habitacionais acabam reforçando esse modelo, privilegiando lógicas privadas de exploração do valor da terra urbana que contribuem para a alocação desigual da população.

Nesse sentido, o Plano de Melhoramentos Urbanos para Campinas elaborado por Prestes Maia é um bom exemplo do efeito da legislação e investimentos públicos concentrados na região central da cidade contribuindo para a segregação dos pobres nas áreas periféricas. Sua proposta era a constituição e renovação do centro da cidade através de um sistema viário que o privilegiava e que concomitantemente contribuiu para a formação da periferia urbana ao seu redor. Esse plano foi lentamente implantado ao longo de duas décadas, com maior intensidade após a Segunda Guerra Mundial.

De modo semelhante, o modelo estatizado de produção habitacional implementado no Brasil pós $1964^{10}$ forneceu atendimento diferenciado da população e essa "segmentação do acesso implicou na segregação espacial, expressão das diferenças de renda no mercado de trabalho" (Arretche, 1990, p. 241). Isso porque apesar da ênfase na construção de moradias para a população mais pobre, a formatação do seu financiamento tornou o sistema lucrativo. De forma que os custos foram repassados para os beneficiários, diminuindo as possibilidades de contemplar pessoas de mais baixa renda $^{11}$.

\footnotetext{
${ }^{10}$ Sistema Financeiro Habitacional - SFH e Banco Nacional de Habitação - BNH.

${ }^{11} \mathrm{O}$ argumento de Arretche (1990) é que esse sistema de política apresentava uma contradição entre um modelo de política estatal e um modelo privatista, isto é, tomava o financiamento da política habitacional de tipo produtivo a partir da lógica privada de retorno do investimento. De modo que de acordo com a lógica privatista, o sucesso ou fracasso da política se computava pelo retorno do investimento, o que
} 
Ou seja, dentre o conjunto de pessoas que conseguiram ser atendidos pelas políticas habitacionais do SFH e BNH houve privilegiados, que foram contemplados por unidades de melhor qualidade em condições de pagamento facilitadas e houve aqueles com casas em piores condições, em locais mais distantes, porém com custos relativamente elevados dadas suas condições econômicas.

Ainda sobre o efeito do Estado na segregação, Marcuse (2004) é definitivo, afirmando que toda divisão espacial que considere diferenciações por status, classe social ou renda requer, implícita ou explicitamente, o uso da força e uma vez que ela é monopólio do Estado,

nenhum padrão residencial, quer incentive, quer contrarie a segregação residencial, poderia existir sem uma ação fundamental por parte do Estado. (...) Se em qualquer sociedade houver segregação ela ocorrerá com a sanção tácita, quando não explícita, por parte do Estado (Marcuse, 2004, p. 29-30).

Acompanhando as ações estatais, o mercado imobiliário realizava especulação dos vazios intermediários entre o centro e a periferia, utilizando como estratégia a compra desses lotes e sua reserva até a implantação de investimentos ao seu redor ou que o atravessasse, o quê, conseqüentemente, elevaria os preços para a venda posterior com alta taxa de lucro. Desse modo, o mercado também teve papel importante na delimitação do preço diferencial do espaço e seu rebatimento sobre a população de destino de certas áreas, contribuindo em grande medida na consolidação do modelo centro-periferia.

Seja via legislação, programas habitacionais ou por iniciativas do mercado imobiliário, o modelo centro-periferia predominou em muitas cidades brasileiras e, entre elas, Campinas. Se ocorreram alterações nas periferias e a segregação hoje se encontra em novos moldes, ainda é marcante a orientação herdada.

Em todo caso, é importante ter em mente que esse foi o molde da segregação ocorrida na Vila Castelo Branco. De modo que nesse bairro podemos dizer que existiu uma combinação de concentração de população de baixa renda, marcada pela diferenciação de infra-estrutura e serviços existentes no centro e contígua mancha urbana, separada pela distância da periferia com piores condições urbanas.

exigia compradores com condições econômicas suficientes para saldar o investimento realizado pelo Estado. 


\subsubsection{Mudanças na expressão do fenômeno}

A partir da década de 1980, tanto a segregação espacial como as periferias urbanas sofreram profundas alterações na forma como se expressavam nas cidades brasileiras e mesmo em outras cidades latino-americanas. Tais transformações afetaram a abordagem desses temas que passaram a ser definidos de forma a dar conta das novidades encontradas.

De modo geral, a periferia deixou de ser o espaço exclusivo de localização da pobreza urbana e passou a ser ocupada também por população de outros estratos socioeconômicos. O que, no entanto, não quer dizer que as cidades deixaram de ser segregadas, mas que a segregação apresenta atualmente contornos distintos dos predominantes anteriormente. Isso ocorreu devido aos processos que veremos a seguir.

Um dos fatores de mudança foi a realização de investimentos nas periferias por parte do Estado. Na cidade de São Paulo, Marques e Bichir (2001) observam que o Estado se fez mais presente nas periferias aumentando a oferta de serviços públicos, tanto em decorrência de grande pressão exercida por movimentos sociais urbanos na década de 1980, quanto por políticas dinamizadas pelo próprio aparelho estatal.

Se por um lado esse investimento melhorou as condições gerais de vida dos moradores dessas áreas, por outro lado, aumentou os custos de moradia pela decorrente valorização da região. Segundo Caldeira (2000), esse cenário marcaria maiores dificuldades para os moradores pobres da periferia por complicarem o uso da autoconstrução como estratégia de acesso à moradia e o aumento do empobrecimento graças à crise econômica dos anos 1980.

Outro elemento que tem contribuído para o encarecimento das periferias seria a construção de condomínios fechados para as classes média e alta. Caldeira (1997 e 2000) reconhece o surgimento dessa nova tendência justificada pelo medo do crime violento a partir da década de 1980, apresentando maior intensidade depois de 1990.

Essa autora identifica os enclaves fortificados como o principal instrumento de uma nova tendência de configuração espacial que mantém a distinção entre grupos concentrados espacialmente apesar da proximidade física. As mudanças espaciais observadas são sobrepostas ao padrão centro-periferia, porém os diferentes grupos sociais estão cada vez mais próximos, apesar de separados por muros e tecnologias de segurança, tendendo a não circulação ou interação em áreas comuns. 
Sabatini, Cáceres e Cedra (2004) observam o mesmo fenômeno dos enclaves fortificados nas cidades chilenas de Santiago, Valparaíso e Concepción. Segundo esses autores, o desenho imobiliário dos condomínios fechados facilita a descontinuidade com o entorno, de forma que tem permitido a ocupação das classes médias e altas fora das tradicionais áreas de concentração destas, mas ainda assim, mantém a separação dessas das classes mais pobres. Dessa forma, as periferias passaram a ser locais de atração de empreendimentos imobiliários desse tipo, que, ainda, se beneficiam de qualidades pouco urbanas ${ }^{12}$ para seduzir os compradores.

No entanto, se essas mudanças espaciais têm feito diminuir a homogeneidade das periferias como local de ocupação das classes mais pobres, por outro lado, mantém a segregação social através de barreiras físicas, morais e simbólicas. Torres (2004) em sua análise sobre a evolução da segregação espacial nos anos 1990 em São Paulo chega a resultados que concordam com Caldeira (2000) e Sabatini, Cáceres e Cedra (2004) quanto ao aumento da auto-segregação dos mais ricos.

Por outro lado, o novo cenário urbano, de acordo com a bibliografia, estaria favorecendo o aumento de favelas e cortiços em São Paulo não mais concentrados nas bordas da cidade, mas distribuídos por diversos pontos dela. Torres (2004) ressalva que o crescimento demográfico das favelas em si não é indicador de segregação caso seja acompanhado de maior heterogeneidade social. No entanto, esse autor observa grande crescimento no grau de isolamento social das populações de favela e das periferias, elevando os níveis de segregação espacial na Região Metropolitana de São Paulo, convergindo com a análise de Kowarick (2000).

Segundo Sabatini, Cáceres e Cedra (2004) outra conseqüência da sobrevalorização do preço da terra nas cidades chilenas tem sido o deslocamento dos pobres para áreas mais longínquas ainda. Torres (2004) também atesta a hipótese da continuidade do processo de periferização em São Paulo, mas pensando em um padrão que transborda a cidade, englobando inclusive a região metropolitana. Ou seja, esse processo de periferização estaria aumentando a população de municípios e distritos mais afastados do centro de São Paulo, constituindo um novo tipo de periferia urbana, como também é observado na Região Metropolitana de Campinas (Baeninger e Gonçalves, 2000; Cunha et al., 2006), como veremos adiante.

\footnotetext{
${ }^{12}$ É comum os anúncios desses empreendimentos destacarem a tranqüilidade, segurança e qualidade de vida devido ao contato com a natureza como atrativos desse tipo de moradia. Para uma análise dessas propagandas, ver Caldeira (2000).
} 
Devido a essas alterações das condições da segregação nos últimos anos, muitos autores têm chamado a atenção para a revisão do modelo radial-concêntrico e para o desenvolvimento de metodologias de medição voltando o foco principalmente sobre a escala da segregação ${ }^{13}$. Como as novas condições de segregação não são mais detectadas principalmente pela distância entre os grupos sociais, a segregação passou a ser observada em maior escala, através de comparações relativas entre partes do tecido urbano.

Sabatini, Cáceres e Cedra (2004) argumentam a favor da importância da escala geográfica da segregação, pois, para eles, a característica marcante das cidades chilenas e latino-americanas seria a segregação em grande escala. Isto é, homogeneidade social presente nos espaços destinados aos mais pobres em contraposição à maior heterogeneidade nos espaços com predominância dos ricos.

Em outras palavras, áreas de concentração das classes mais altas apresentam maior diversidade social, isto é, há existência de diversas faixas socioeconômicas - o que os autores denominam de baixa segregação. Em contraposição, há grandes áreas de elevada concentração de estratos pobres da população que se caracterizam por maior homogeneidade social e conseqüente maior segregação. Dessa forma, seria necessário um ajuste da escala de expressão do fenômeno para melhor captação da segregação da qual se fala.

Sobre a caracterização das cidades latino-americanas, a análise desses autores converge com a de Villaça (1999) e Torres (2004) sobre São Paulo. Esses últimos apontam que as áreas com predominância de pessoas muito pobres são menos diversificadas socialmente e tem havido crescimento demográfico da periferia, em especial um aumento da proporção de pobres nessas áreas. Quanto a Campinas, Cunha et al (2006) vão destacar o mesmo argumento para a cidade para a elaboração do que eles definem como "cordilheira da riqueza", como será mostrado no próximo capítulo.

Como vimos, a distância em relação ao centro ou a evolução histórica da cidade não são os únicos elementos a determinar a qualidade dos espaços residenciais. Como afirmam os autores, novas dinâmicas imobiliárias, diversos movimentos sociais e políticas públicas produziram inúmeras transformações nas periferias "exigindo uma reconsideração de antigos modelos analíticos que descreviam e investigavam essas concentrações populacionais nas décadas de 1970 e 1980" (Torres et al, 2003, p. 99).

\footnotetext{
${ }^{13}$ Ver a esse respeito Bichir (2006); Marques e Torres (2005); Sabatini (2004); Sabatini, Cáceres e Cedra (2004); Torres (2004).
} 
Em Campinas, as mudanças contemporâneas sobre a organização espacial centro-periferia também podem ser sentidas. Será apresentado no próximo capítulo como a dinâmica espacial foi registrada na cidade e sua região metropolitana de maneira semelhante aos aspectos indicados pela literatura consultada, de modo que esses enfoques também podem ser tomados como referência para pensar o contexto de estudo.

\subsection{Abordagem de redes sociais: possibilidades teóricas e metodológicas}

Nesse item, serão apresentadas as linhas gerais da análise de redes sociais adotada nessa pesquisa. A intenção não é uma explanação exaustiva da bibliografia que tem se dedicado ao assunto, mas apresentar uma resenha enxuta das referências conceituais e metodológicas utilizadas e estudos empíricos que dialoguem com a questão da influência do espaço sobre as redes sociais.

É importante sublinhar a análise de redes não como um corpo teórico em si, mas como um método, como uma abordagem que permite estudos diversificados utilizando diferentes referenciais teóricos para compreensão de estruturas sociais em geral. Esse método entende as redes como padrões mais ou menos estáveis de relações sociais entre atores interdependentes (Klijn, 1998). Marques (2006) completa essa definição afirmando que as redes representam vínculos entre indivíduos, organizações, entidades que estruturam várias situações sociais e influenciam o fluxo de bens materiais, idéias, informação e poder.

A análise de redes sociais tem sido utilizada para enfocar o emaranhado de relações nas quais os indivíduos estão inseridos na sociedade, voltando o olhar sobre as estruturas e padrões desses relacionamentos. Sendo que a principal vantagem dessa abordagem é a integração dos indivíduos em seus contextos relacionais, o que permite análises mais abrangentes de processos sociais para além das considerações sobre os atributos individuais dos sujeitos envolvidos em determinado fenômeno.

Os dados de atributos são aqueles relacionados às atitudes, opiniões e comportamentos dos agentes e dizem respeito às propriedades, qualidades ou características pertencentes aos indivíduos ou grupos (Scott, 2000). De forma que esses dados são captados através de análise de variáveis, como exemplo, os atributos de renda, escolaridade, sexo, localismo, entre outros. As análises baseadas em atributos 
explicam parte dos fenômenos, mas não abarcam processos e dinâmicas importantes somente captadas pelo estudo direto dos vínculos e relações.

Esse tipo de unidade analítica compõe os chamados dados relacionais, ou seja, os contatos, laços e conexões que não se reduzem aos agentes individualmente, mas refere-se a um agente com outro. Esses são os dados que podem ser captados e trabalhados pela análise de redes sociais (Marques, 2000; Scott, 2000).

No entanto, apesar dessa separação analítica, ambas as dimensões compõem o mundo social de modo que mesmo as abordagens que ressaltam as redes consideram atributos e relações de forma conjunta na apreensão e análise da estrutura social. Segundo Emirbayer (1997), tanto atributos quanto relações não se cristalizam nos indivíduos, estão em dinâmica constante e se afetam mutuamente de maneira contínua ao longo dos processos sociais. Congelamos esses dados na análise apenas para poder empreendê-la.

Segundo Knoke e Kuklinski (1982, apud Knoke, 1990, p. 9), há uma premissa explícita na análise estrutural desse tipo que considera que

the structure of relations among actors and the location of individual actors in the network have important behavioral, perceptual, and attitudinal consequences both for the individuals units and for the system as a whole. ${ }^{14}$

A conclusão de Knoke (1990) sobre essa premissa é que tanto as formas quando os conteúdos das relações entre as posições sociais têm significantes conseqüências sobre a formação de atitudes e comportamentos políticos. Apesar de referir-se especificamente a redes de políticas, essa premissa seria válida para qualquer tipo de interação entre indivíduos.

No entanto, apesar de considerar as estruturas nas quais os indivíduos estão inseridos como importantes fatores de incidência sobre seus comportamentos, a abordagem de redes incorpora a ação dos indivíduos nas estruturas também, não tomando a incidência de padrões de forma definitiva e rígida sobre a sociedade.

A investigação dos vínculos, posições e estruturas das redes se distinguiria fundamentalmente das análises estruturalistas clássicas nas ciências sociais por "não

\footnotetext{
14 "A estrutura das relações entre os atores e da localização do ator individual na rede tem importantes conseqüências comportamental, perceptual, e atitudinal tanto para as unidades individuais, quanto para o sistema como um todo". Knoke, D. e Kuklinski, J. Network analysis. Beverly Hills, Calif.: Sage, 1982, p. 13. Tradução minha.
} 
partir de postulações de larga escala sobre as estruturas sociais, ou tampouco tentar derivar delas os fenômenos sociais" (Marques, 2000, p. 34). Segundo Knoke (1990), outros modelos de análise estrutural se preocupariam apenas com os parâmetros estimados de medição dos efeitos estáveis das variáveis causais. De acordo com sua argumentação, essas não seriam análises estruturais no sentido relacional como ele o entende.

De acordo com a abordagem adotada por esse trabalho, a estrutura da rede fornece elementos para entender seus processos mais dinâmicos, da mesma forma como esses processos ocasionam rearranjos dos componentes da rede. Isso ocorre porque a dinâmica da rede está dialeticamente relacionada com sua estrutura, de forma que cada uma condiciona parcialmente a outra ao longo do tempo (Emirbayer, 1997).

Conhecer como os atores estão conectados uns aos outros e a configuração estrutural permite identificar formas e conteúdos através dos quais circulam bens e os efeitos que esses processos têm sobre os participantes das redes (Knoke, 1990). De forma que a estrutura da rede pode representar resultados dos processos dinâmicos nos quais ela está inserida. É a partir dessa consideração que se entende que o estudo de padrões de relacionamentos expressos nas redes pode subsidiar a compreensão de fenômenos que a influenciam.

De acordo com a definição de segregação como um fenômeno de concentração de população homogênea em espaço delimitado e, como acontece no caso de estudo, afastado das demais áreas da cidade, é possível que a segregação seja um fenômeno de restrição de contatos sociais. Isso é, a segregação espacial tenderia a impor certos constrangimentos às possibilidades relacionais dos indivíduos que estão submetidos a essa forma de ocupação espacial. Se confirmada a hipótese de restrição relacional nos primeiros anos do bairro é possível que as redes tenham sido beneficiadas em termos de aumento de tamanho, variabilidade das esferas de sociabilidade e do localismo dos nós devido a alteração espacial pela qual passou a Vila Castelo Branco.

Contudo, além da avaliação dessa hipótese, interessa conhecer quais foram os tipos de mudanças pelas quais as redes dos moradores desse bairro passaram. De forma que a descrição dessas mudanças e os dados empíricos levantados possam iluminar a compreensão da relação entre mudança espacial e redes sociais.

De fato, o que se espera da análise empreendida é mais uma descrição das mudanças das redes pela incidência de períodos coincidentes com uma alteração 
espacial. Dito de outra forma, busca-se apontar quais as alterações que a mudança da configuração espacial influenciaram nas redes sociais de pobres urbanos.

\subsubsection{Dinâmicas das redes}

Como captar a dinâmica das redes é um dos questionamentos que se coloca para esse tipo de análise. O congelamento de momentos como retratos das relações ou mesmo sucessões estáticas de representações da estrutura social são formas utilizadas para captação de elementos para a análise. Contudo, as estruturas desenhadas pelos sociogramas são na verdade representações de indivíduos ou entidades que se ligam, mas não conseguem expressar o que estruturam essas relações, nem as relações propriamente ditas. De fato, a dinâmica social impõe limitações para ser apreendida em si. Pode-se apenas observar momentos estáticos para compreender padrões e permanências que indicam algumas tendências das mudanças.

No entanto, apesar dessa dificuldade, a abordagem de redes não é estática. De acordo com Emirbayer (1997), ela se compõe pela imersão dos atores sociais em suas relações e histórias que estão continuamente sendo produzidas e reproduzidas na interação. Isso porque essa interação envolve trocas de diversos tipos, tanto de elementos materiais, como dinheiro ou recursos quaisquer, quanto bens imateriais, como histórias, informações, trocas simbólicas e mesmo troca de contatos.

A relação de diversas trocas subjacente as relações entre indivíduos que carregam esses elementos em si impõe incertezas nas relações, no sentido de que é um processo incessante de elaboração do mundo social. O enfoque sobre as redes sociais tenta dar conta das possibilidades de aquisição ou perda de recursos através das relações sociais, aquisições essas que alteram a estrutura das relações e a distribuição de bens entre os indivíduos.

Devido a essas interações, nos estudos sobre a pobreza, principalmente a concentrada espacialmente, as redes sociais são tidas como elementos capazes de suprir algumas carências dadas pelas condições socioeconômicas (Marques, 2007 e Pavez, 2006a). Isso porque através delas os indivíduos teriam possibilidade de se inserir em círculos sociais mais amplos e diversificados que podem agregar referências, facilitando a aquisição de determinados bens. 
Uma das vantagens da abordagem de redes, de acordo com Marques (2006), é a integração dos atores em seus contextos relacionais. Em estudo voltado para a dinâmica do tecido relacional do Estado, esse autor observou uma combinação ambígua de incentivos à transformação e inércia como características das relações que o compõe. Isso porque as estruturas relacionais constrangem escolhas, configuram acesso diferenciado a bens e instrumentos de poder, influenciam os resultados da política, facilitam ou não certas alianças. De fato, essas tendências de transformação e inércia não são exclusivas da teia estatal, mas próprias a qualquer tecido relacional em decorrência de dinâmicas próprias de redes sociais quaisquer.

Ao tomarmos essas tendências como características das redes sociais de forma geral, podemos utilizar esses elementos para compreender dinâmicas de conformação das redes em relação ao espaço urbano.

Segundo Klijn (1998), a diversidade de atores na rede, cada qual com metas próprias, conduzem a uma interação estratégica entre eles em função das relações estabelecidas. De acordo com este autor, uma das características das redes sociais é a interdependência dos atores devido à dependência dos recursos que estão distribuídos entre eles, de forma que o intercâmbio desses recursos gera padrões de relações estáveis entre os envolvidos.

Também a diversidade de atores presentes nas redes sociais conduz a uma interação estratégica, já que cada qual teria um conjunto de metas próprias. Tanto a interdependência quanto a interação estratégica fomentam padrões de relações mais ou menos duradouros entre os atores. Esses padrões podem ser observados em termos de freqüência, proximidade e centralidade, que caracterizam as posições dos atores em uma rede e as conseqüências dessa posição para o alcance de seus objetivos, de acordo com Klijn (1998).

No entanto, a diversidade de atores presentes nas redes e a existência de estratégias múltiplas de acesso para cada indivíduo ou grupo delineiam certa contingência na forma como os atores se relacionam entre si e distribuem os recursos que fluem entre eles de forma a assinalar a dinâmica e abertura à mudança presente nessas estruturas (Marques, 2006).

O recorte de pesquisa privilegiou os aspectos de mudança e contingência da rede em detrimento da análise das posições dos indivíduos e quais seriam os recursos que fluem nessas redes. Acredita-se que as mudanças captadas são os elementos que mais podem dizer sobre a influência da alteração espacial observada no caso estudado. 


\subsubsection{Pensando redes e espaço}

A pesquisa pretendeu entender a influência do espaço sobre as redes sociais, partindo da premissa de que o espaço pode conferir certos benefícios ou constrangimentos às oportunidades relacionais disponíveis aos indivíduos, refletindo na composição de suas redes. A soma de restrições espaciais e relacionais pode operar como um mecanismo de dificuldade a melhores condições de vida, principalmente em termos econômicos, pensando na renda de indivíduos em situações de pobreza. Outra premissa aqui implícita é a de que as possibilidades de saída da pobreza podem ser encontradas em fatores que não somente diretamente econômicos, mas que outros aspectos, como segregação e redes, podem contribuir.

Kaztman (2001) chama a atenção para algumas políticas públicas que descuidam da integração dos pobres urbanos na sociedade, “operando como se só o melhoramento de suas condições de vida os habilitaria para estabelecer (ou restabelecer) vínculos significativos com o resto de sua comunidade" (p. 172, tradução minha). Contudo, para esse autor, essa conduta não faz com que essas políticas quebrem o léxico da exclusão social dada pelo isolamento social dos pobres urbanos. Pelo contrário, segundo Kaztman (2001) o estabelecimento de vínculos frágeis entre os diferentes estratos sociais só contribui para o aumento da distância entre ricos e pobres na sociedade.

No fundo, a argumentação do autor explicita como as relações são coconstruídas com os atributos, e ambos são passíveis de intervenção. Essa conexão permite então que interferindo em um se altere o outro, como apontado por Mische e White (1998). Se considerarmos que o espaço é um elemento que interfere na composição dos atributos dos indivíduos, as alterações espaciais pelas quais passaram os moradores da Vila Castelo Branco podem ter influenciado conjuntamente tanto os atributos dos indivíduos, quanto suas redes, em processo contínuo de fornecimento e restrição de benefícios. De modo que o espaço, ao influenciar a configuração de padrões de relações pode estar inibindo ou contribuindo - de maneira combinada com as próprias relações - as condições de acesso dos indivíduos e as possibilidades de saída da pobreza de forma considerável.

No caso de estudo sobre a pobreza e, principalmente quando esta está posta em relação com o espaço, considerar tanto atributos como relações se torna fundamental. Nas palavras de Marques (2007, p. 30) isso ocorre porque 
$\mathrm{O}$ acesso dos indivíduos às estruturas de oportunidades que conduzem às condições sociais em geral, e às situações de pobreza em particular, é mediado pelos padrões de relação que esses indivíduos têm com outros indivíduos e com organizações de variados tipos. Dado que esses indivíduos se localizam no espaço (uma propriedade das redes denominada propinqüidade), as conexões de rede também funcionam como elemento de ligação entre espaços mais ou menos segregados. Nesse sentido, redes com maiores proporções relativas de pessoas não habitando o mesmo local de moradia do ego tenderiam a integrar mais intensamente os indivíduos.

Da mesma forma, essa integração conseqüentemente facilita a fluidez de recursos que as diferentes localidades podem oferecer. Por exemplo, um indivíduo segregado sem acesso à informação sobre postos de trabalho ou atendimento médico, ao ter contato com um indivíduo de um local que tenha esses recursos pode se beneficiar dele nesse outro espaço. Ao passo que um indivíduo segregado sem contato com indivíduos em locais com esses recursos tem maiores dificuldades de alcançá-los. Ou seja, as oportunidades presentes em cada bairro oferecem certos bens a seus indivíduos e o contato entre pessoas de locais diferentes proporciona maior circulação desses bens.

Além de dinâmicas relacionais diversas, a própria localização espacial dos indivíduos é um fator de incidência sobre as redes, de acordo com a disposição de recursos materiais, imateriais e também relacionais, como observado por Almeida e D’Andrea (2005) na favela de Paraisópolis em São Paulo ${ }^{15}$. A observação etnográfica registrada nesse caso foi que morar perto das áreas mais ricas aumenta a possibilidade de encontrar emprego e acessar benefícios, "devido ao fluxo de informações e à diminuição do custo do transporte para o empregador" (Almeida e D’Andrea, 2005, p. 202). Ou seja, apesar da precariedade da favela, sua localização é fonte de recursos sociais e econômicos para seus moradores.

Diferentemente de Paraisópolis, onde o próprio fato de morar nessa favela e não em outra significa motivo para atração e obtenção de recursos, a moradia na Vila

\footnotetext{
${ }^{15}$ Como visto anteriormente, o caso de Paraisópolis seria de relativa segregação social devido à marcada diferenciação sócio-econômica entre seus moradores e os vizinhos apesar da proximidade territorial, ou seja, há o contato espacial, mas delimitada interação social. Esse tipo de segregação se aproxima mais da estudada por Caldeira (2000) e explicada pelo medo e a fala do crime, diferentemente da segregação espacial da Vila Castelo Branco em seus primeiros anos.
} 
Castelo Branco no seu início não tinha essa conotação. Pelo contrário, sua segregação espacial e suas condições precárias eram inclusive motivos para que seus moradores omitissem onde moravam, por vezes até mesmo por vergonha (Gonçalves, 2002).

No estudo de Almeida e D'Andrea (2005) fica patente a relevância do local como fornecedor de ativos e credenciais para os indivíduos. Segundo os autores, "percebe-se que alguns aspectos, como localização e alcance das redes associativas, são fatores importantes na diferenciação dos pobres, conforme situações de maior ou menor vulnerabilidade" (Almeida e D’Andrea, 2005, p. 195, grifos meus). E são esses aspectos que diferenciam as condições de quem mora em Paraisópolis de quem morava na Vila Castelo Branco no seu início.

No entanto, de maneira complementar ao espaço, as próprias redes de relações sociais funcionam como ativos potenciais e quanto mais recursos elas têm, mais recursos conseguem obter, segundo Almeida e D'Andrea (2005). Por outro lado, se existem poucos recursos nas redes, a probabilidade de obtenção de novos recursos se torna mais difícil.

A questão do leque de recursos disponíveis para os indivíduos, entretanto, pode não ter relação apenas com a quantidade de pessoas nas redes. Se os vínculos estabelecidos apresentam características semelhantes ao indivíduo em questão, podem ser redundantes em termos de acesso.

Essa semelhança entre os vínculos compõe o chamado princípio de interação homofilica estudado por Granovetter (1973), segundo o qual relações regidas por esse princípio tendem a abrir poucas opções para a mudança. Isso porque a semelhança de características entre os indivíduos verifica-se também no que diz respeito às informações e a seus recursos sociais.

A homofilia de informações seria estabelecida através de grande freqüência e forte intensidade dos contatos, algo que geralmente ocorre no âmbito da família e da vizinhança, sociabilidades nas quais se estabelecem os chamados vínculos fortes. Em contexto de pobreza urbana, redes homofílicas podem ter um efeito inercial agravante para a reprodução do circuito da pobreza.

O tipo de interação mais promissor segundo Granovetter (1973) seria a dos vínculos fracos, resultantes de contatos menos intensos e freqüentes e que por isso possuem características distintas daquelas encontradas entre os chamados vínculos fortes. Esses tipos de relações se desenvolvem especialmente em ambientes institucionais ou organizacionais, permeados por maior formalidade e diversidade de 
indivíduos, além de serem locais onde circulam grande quantidade de informações (Marques, no prelo).

A novidade dada por relações heterofílicas, bem como por constantes transformações ocorridas pela entrada e saída de pessoas, mudanças nos conteúdos e bens que nelas fluem, são elementos característicos da contingência das redes. De modo que essa interação heterofílica traria maiores possibilidades de inovação para os indivíduos.

A associação dos efeitos da homofilia à concentração espacial pode reforçar a precariedade do grupo por várias vias. Kaztman (2001) elenca cinco delas, começando pela interação com vizinhos cujas habilidades, hábitos e estilos não promovem resultados exitosos de acordo com os critérios predominantes na sociedade. Também, pelas redes da vizinhança serem ineficazes para a obtenção de emprego ou de informação sobre emprego e oportunidades de capacitação. Em terceiro lugar, pela mesma instabilidade laboral gerar dificuldades para a manutenção de instituições de bairro básicas e níveis adequados de organização e controle social informal. Adicionalmente, pelo fato das crianças e os jovens carecerem de modelos exitosos na sociedade e de oportunidades de exposição a esses modelos. E, por fim, pelas situações de desemprego persistente aumentar a predisposição à exploração de fontes ilegítimas de rendimento.

Desse modo, a bibliografia assinala que a redundância de contatos dada pela homofilia combinada com a concentração espacial alimentaria uma espiral de precariedades que constrange as oportunidades dos indivíduos.

Outro fator que atua sobre as condições das redes sociais é o mecanismo chamado de "economia dos vínculos", que se relaciona diretamente com a renda dos indivíduos. De acordo com esse mecanismo, pessoas com menos recursos econômicos teriam maiores dificuldades para arcar com os custos de criação e manutenção de vínculos sociais, que envolvem tanto dimensões econômicas, como emocionais e de tempo ou mobilização pessoal. De forma que esses custos gerariam redes menores, mais locais e menos diversas para os indivíduos mais pobres (Marques, 2007).

Além da dificuldade em construir vínculos, os gastos necessários para manter comunicação e deslocamentos para encontros entre pessoas de diferentes esferas e localização podem ser ainda mais pesados. O que torna muito comum que "parcelas inteiras da rede sejam abandonadas ao longo do tempo" (Marques, 2007, p. 77), de forma a restringir o tamanho e a diversidade da rede aos contatos menos custosos. 
Em parte, os vínculos originados em esferas de sociabilidade primária, como família e vizinhança, seriam os mais prováveis de se manter nas redes de acordo com a lógica da "economia dos vínculos". Nesse sentido, esse mecanismo atua no mesmo sentido de restrição de oportunidades relacionais e ainda traz como conseqüência uma tendência à homofilia das relações, pela predominância dos vínculos fortes.

Considerando essas tendências, em geral negativas para o estabelecimento de redes vantajosas para os indivíduos segregados e pobres, o estudo proposto verificou como a alteração na condição espacial pode interferir para a conformação de redes mais favoráveis aos indivíduos.

\subsubsection{Algumas definições de pesquisa das redes sociais}

Há muitas formas de entender as relações sociais, mesmo quando estamos pensando em termos de análise de redes sociais. Por isso é importante definir algumas idéias e conceitos envolvidos no trabalho aqui realizado.

Existem diferenças conceituais de redes que implicam distintas formas de construção e de informações que elas nos disponibilizam (Marques, 2007). São principalmente três. Alguns estudiosos analisam redes de comunidades, que envolvem todo o ambiente relacional que cerca um indivíduo no contexto de determinado tema. Um segundo tipo seriam as redes egocentradas ou egonets que consideram apenas os contatos primários de um indivíduo.

Por fim, há as redes totais dos indivíduos, também chamadas de redes pessoais. São aquelas que correspondem a todos os vínculos de relações da pessoa e são redes organizadas de acordo com as esferas de sociabilidade. É esse tipo de rede a utilizada nesse estudo, por acreditar que nesse nível relacional é possível captar as dinâmicas estabelecidas entre os indivíduos que compõe cada rede e os entrevistados, abarcando mais contatos que os imediatos ao ego.

Esse tipo de rede é composto pelo ego, pelos nós e pelas relações. $\mathrm{O}$ ego é o indivíduo do qual partem as relações e os nós envolvidos na rede, sendo a origem desta; é o indivíduo entrevistado no caso estudado. Os nós de forma geral são as unidades das 
redes, que podem ser tanto pessoas quanto grupos, organizações e entidades ${ }^{16}$. Nesta investigação, os nós são as pessoas existentes na rede com as quais o ego estabelece relações e que foram citadas por ele na construção de sua rede, sendo que o próprio ego pode ser tomado como um nó. As relações estabelecidas entre os nós são os vínculos ou laços sociais.

As informações que vão compor as redes podem ser coletadas através de entrevistas com a utilização de um questionário próprio ou por outras fontes de dados relacionais como documentos organizacionais ou históricos ${ }^{17}$, por exemplo.

Os modelos de representação das redes são variados, mas em geral representam a matriz de relacionamentos elencados pelos dados. O sociograma é uma dessas formas de representação das entidades e suas ligações em uma rede. Ele foi desenvolvido como técnica que permite a visualização dos papéis sociais de acordo com a posição do indivíduo na rede, pela observação de padrões de relacionamentos difíceis de serem apreendidos apenas pela narrativa (Scott, 2000). É esse tipo de representação gráfica a utilizada para as análises aqui desenvolvidas.

Enquanto as redes sociais correspondem aos vínculos existentes entre os indivíduos, há partes das redes que se constituem de acordo com uma combinação entre laços e seus conteúdos, conformando esferas especializadas de interação, chamadas de esferas de sociabilidade. Elas são conjuntos de pessoas que fazem parte da sociabilidade dos indivíduos com o predomínio de uma espécie de especialização, como por exemplo, a esfera da amizade, a esfera da família, entre outras (Marques, 2007).

A definição do tipo de esfera a que pertencem os nós de uma rede é elaborada cognitivamente pelo próprio indivíduo, uma vez que o reconhecimento do repertório veiculado e sua classificação dependem da forma como cada indivíduo concebe sua rede. Nesse sentido, Marques (2007) justifica o uso do dado cognitivo a partir da consideração de que "a maneira pelas quais os indivíduos entendem as suas redes é o que as define e orienta o seu uso social cotidiano" (p. 7). De forma que o que é captado pelo método se baseia na compreensão e no uso que os sujeitos fazem de suas redes, sendo suficiente para entendê-las.

\footnotetext{
16 Lavalle, Castello e Bichir (2006), por exemplo, utilizam como unidade analítica das redes as organizações da sociedade civil e não os indivíduos. Nesse caso também, as entidades traçam relações informais que vão além das reguladas pelas instituições que as estruturam.

${ }^{17}$ Ver, por exemplo, Toledo (2005) que trabalhou com dados organizacionais. Gould (1991) e Padgett e Ansell (1993) basearam suas análises em dados históricos sobre a família Médici na Itália e a Comuna de Paris, respectivamente.
} 
A própria denominação de esfera tem por intuito abarcar partes do mundo social tal como cada indivíduo o entende e organiza. E esse mundo é composto tanto por pessoas, quanto por repertórios e recursos. Os nós das redes sociais seriam os representantes desses mundos, entendendo que cada indivíduo carrega consigo esses elementos - repertórios e recursos.

Entende-se que a variação de repertórios dada pela diversidade da sociabilidade englobaria uma variação de recursos disponíveis a cada uma dessas esferas. Por exemplo, a esfera de trabalho tende a circular informações de trabalho que podem repercutir tanto como qualificação pelo aprimoramento do conhecimento a partir da troca de idéias, quanto como oportunidades. No entanto, os repertórios não são fixos a tal ou qual esfera. Sendo que mesmo na esfera da igreja, pode circular as mesmas informações sobre trabalho, por exemplo.

Da mesma forma que não há rigidez nos elementos componentes das esferas de sociabilidade, as relações estabelecidas entre os sujeitos não necessariamente se restringem a uma ou outra esfera de sociabilidade. $\mathrm{Na}$ verdade, as relações podem se constituir como relações multiplex, denominação dada por Ferrand, Mounier e Degenne (1996). Para esses autores, a multiplexidade dos tipos de vínculos significaria intersecção entre duas redes ou mais, entendendo que cada grupo de sociabilidade conformaria um tipo de rede e o agrupamento desses tipos resultaria na rede total ${ }^{18}$.

No entanto, as esferas de sociabilidade, como aqui entendidas, não seriam redes em si, mas partes constituintes da rede pessoal. Isso porque a compreensão de rede adotada reconhece que esta é composta pelos vínculos desenvolvidos pelo indivíduo, independente do tipo, força ou esfera de sociabilidade. E que a partir dessas diferenças existentes entre as interações pode-se apreender as dinâmicas que envolvem a fluidez de recursos na rede.

Mische e White (1998) também trabalham com a idéia de especialização de relações nas redes. Para esses autores, cada tipo de rede está acompanhado por um conjunto de histórias em dado período de tempo, sendo que as relações sociais são

\footnotetext{
${ }^{18}$ Nesse ponto é preciso esclarecer uma diferença fundamental entre a forma como se tem trabalhado aqui e o entendimento que esses autores têm sobre redes. O que se definiu como esferas de sociabilidade nesse trabalho, para Ferrand, Mounier e Degenne (1996) seriam as próprias redes sociais. Por isso os autores falam de intersecção entre redes onde designamos intersecção entre esferas para pensar a multiplexidade dos vínculos. Essa diferença decorre de pequeno deslocamento de perspectiva, pois para esses autores o que se está chamando de rede social é designado como sistema relacional. De fato, o entendimento do que são redes e o tecido relacional na sociedade é muito diverso, operando em várias escalas e subdivisões distintas entre os estudos. A esse respeito, Mayer (1987) traça um breve panorama sobre algumas dessas variações.
} 
produzidas pelo cruzamento de conjunto de redes de relações e conjunto de histórias que são constituídas especializadamente como domínios de interações discursivas.

Esses autores chamam essa composição especializada de network domains ou simplesmente netdoms. Esses domains, ou domínios, podem ser concebidos por uma disposição de signos - histórias, símbolos, registros, idiomas, modelos gramaticais e marcas corporais - que caracterizam um campo de interação especializado em particular. Tais domínios seriam produzidos e sustentados pelos atores através de ferramentas sociais fornecidas pelo discurso e outras redes de interações que compõem os repertórios disponíveis aos indivíduos.

Se as esferas de sociabilidade são constituídas pela circulação de relações e repertório específico, elas apresentam certa semelhança com a definição de network domais ou netdoms de Mische e White (1998). Nas palavras de Marques (2007, p. 45),

Em termos concretos as esferas incluem certos conjuntos de indivíduos e organizações, as relações que se estabelecem entre eles (de vários tipos e em constante transformação), assim como determinadas identidades, conjuntos de signos e padrões discursivos no sentido de Mische e White (1998) e White (1995). Nesse sentido, as esferas guardam semelhança com os network domains daqueles autores, embora busquem descrever contextos mais específicos, estruturados e duradouros. Talvez seja possível dizer que as esferas, conforme definido aqui, incluem as versões mais estáveis dos netdoms de Mische $(2000)^{19}$.

Essa mesma consideração sobre as esferas de sociabilidade pode ser utilizada no âmbito do presente trabalho. Desse modo, como cada esfera de sociabilidade envolve um tipo de repertório especializado, a existência de diversas esferas agregam maior diversidade de repertórios para os indivíduos, entendendo os repertórios no sentido mais amplo como exposto anteriormente.

Marques (2007) comprovou que as sociabilidades desenvolvidas em ambientes institucionais ou organizacionais tendem a ser mais valiosas para os indivíduos em termos de possibilidades relacionais. Isso acontece, pois além da diversidade de

\footnotetext{
${ }^{19}$ MISCHE, Ann \& WHITE, Harrison"Between Conversation and Situation: Public Switching Dynamic across Network Domains". In: Social Research, setembro de 1998. WHITE, Harrison. "Network switchings and bayesian forks: reconstructing the social and behavioral sciences". In: Social Research: An international quaterly of the social sciences. Vol 62, No 4, 1995.
} 
repertórios oferecidos por contatos distintos, o próprio ambiente relacional se liga a uma estrutura de circulação de recursos.

De modo complementar, a restrição de esferas de sociabilidade diminui as oportunidades relacionais e, conseqüentemente, o acesso a certos mundos sociais. Uma redução da sociabilidade à esfera da família, vizinhança e amizade, que compõe a sociabilidade primária, poderia ter efeitos negativos pela homogeneidade de repertórios que circulam nesse âmbito. Esse aspecto, inclusive, se relaciona com o que já foi dito sobre o princípio de interação homofílica de Granovetter (1973). Por outro lado, Almeida e D'Andrea (2005) e também Marques (2007) mostraram a relevância que laços entre familiares e conterrâneos podem ter para a obtenção de diversos tipos de recursos, principalmente emprego e moradia para migrantes recém chegados em São Paulo.

Com isso em mente, esse trabalho desenvolveu o estudo do comportamento das esferas de sociabilidade para observar que tipos de sociabilidades podem estar sendo criadas ou perdidas de acordo com a mudança espacial. Juntamente com as outras características estudadas, a variação da sociabilidade pode favorecer a população de baixa renda e é um elemento importante para entender as dinâmicas relacionais das redes sociais.

Junto com as esferas de sociabilidade, o localismo é uma das principais características das redes nesse estudo, justamente por ser a dimensão diretamente relacionada ao espaço. Apesar da impossibilidade de isolar efeitos de fenômenos sociais na interpretação da sociedade, a análise desse componente permite aferições da influência da mudança da segregação espacial sobre as redes. Isso porque a partir do localismo dos nós da rede é possível observar a expansão ou diminuição dos contatos pertencentes a outros espaços da cidade. De modo que é o componente que mais ajuda a entender a dinâmica espacial sobre a dinâmica relacional, por considerar diretamente o pertencimento espacial dos indivíduos que compõe cada rede.

É preciso sublinhar que apesar da segregação poder limitar as oportunidades relacionais dos indivíduos, ela é uma dimensão do espaço por definição e não é em si determinante do localismo dos nós da rede. Marques (2007), por exemplo, encontrou indivíduos de locais segregados em São Paulo com redes de relações extensas que percorrem diversos bairros da cidade e mesmo fora dela, ainda que contrariando a tendência esperada pela literatura. 
De fato, o estudo do localismo poderia até mesmo ser pensado considerando diversos locais da cidade. Contudo, no caso da Vila Castelo Branco o localismo foi interpretado através da dicotomia entre pessoas que moram dentro do bairro e pessoas que moram fora dele. Essa escolha analítica considerou o fato do bairro ser segregado nos seus primeiros anos, o que daria limites locais bem específicos para seus moradores. De modo que a definição de dentro e fora do bairro daria conta da dicotomia espacial dada pela segregação inicial da Vila Castelo Branco.

O que nos interessa não é definir se um espaço segregado qualquer teria ou não redes locais, mas entender como esse aspecto é impactado pela mudança da condição espacial e observar quais seriam as conseqüências desse impacto.

Ou seja, como a mudança espacial da segregação para a integração pode ter favorecido as redes em termos de diversificar as oportunidades relacionais, tendo em mente que o contato com nós pertencentes a locais diversos tende a favorecer o acesso aos recursos disponíveis para os indivíduos. A premissa implícita nesse raciocínio é que só o fato do nó que se tem vínculo estar fora do bairro já seria possível trazer benefícios distintos dos existentes nesse local. 


\section{CAP. 2 - REDES NA VILA CASTELO BRANCO}

\subsection{Campinas e seu desenvolvimento urbano: observando a segregação na cidade}

Para entender os processos de segregação na cidade de Campinas, resenho um breve relato de sua história urbana recente, ressaltando principalmente os elementos que contribuíram nesses continuados processos. Apesar de grande parte da literatura de referência sobre segregação tratar da dinâmica espacial principalmente na cidade de São Paulo, Campinas apresenta um desenvolvimento urbano marcado por continuados processos de segregação espacial da população, que inclusive tem se reproduzido no contexto metropolitano do qual a cidade é sede.

Em geral, a literatura sobre Campinas dá grande destaque ao fato da cidade ter se desenvolvido como rota de passagem para o caminho de Goiás, o quê teve como resultado a construção de importante estrutura viária que contribuiu para seu crescimento urbano. A relevância histórica da cidade como rota de passagem é tomada como causa do crescimento populacional advindo da chegada de imigrantes, um dos principais motivos de expansão da cidade. A essa dimensão demográfica soma-se um intenso processo de urbanização, com periferização do crescimento físico-territorial, que contribuíram para que ela se tornasse a terceira cidade mais populosa do estado de São Paulo ${ }^{20}$ (Baeninger, 1996; Caiado e Pires, 2006; Caiado et al., 2002; Cunha et al., 2006 e Prefeitura Municipal de Campinas, 2004).

De acordo com essa bibliografia, com a crise da economia cafeeira nos anos 1930 e com incremento na industrialização no país, a cidade "foi o palco privilegiado do processo de interiorização do desenvolvimento econômico no estado de São Paulo" (Caiado et al., 2002, p. 123) acompanhando a capital devido a sua proximidade física e boa infra-estrutura viária e industrial. Nesse momento, esses processos econômicos somados a investimentos na construção civil, investimentos para a expansão industrial e posteriormente, com a inauguração da via Anhanguera ${ }^{21}$ atraíram muitos imigrantes $^{22}$ a

\footnotetext{
${ }^{20}$ Ficando atrás apenas da capital e do município de Guarulhos. Os autores que estudam Campinas ainda ressaltam sua importância regional, força econômica e, tratando da Região Metropolitana de Campinas, o fato de ser um dos mais importantes pólos tecnológicos brasileiros. Ver, por exemplo, Cunha et al. (2006).

${ }^{21}$ A Via Anhanguera foi inaugurada em 1948, contribuindo para o direcionamento de fluxos migratórios para o município no início dos anos 1950 (Baeninger, 1996).
} 
procura de empregos, de forma que a cidade se expandiu com grande força, tanto em termos populacionais como pelo crescimento de seu perímetro urbano.

Devido à perspectiva de expansão urbana, em 1934, Prestes Maia elabora o Plano de Melhoramentos Urbanos para Campinas. As diretrizes desse Plano baseavamse em concepções de quatro necessidades de uma cidade, que eram: (a) rápida comunicação interna, (b) funções definidas espacialmente, (c) estabelecimento de espaços para sua expansão e (d) devido ao histórico de rota de passagem de Campinas, investimento no seu centro também como uma rota de comunicação dinâmica (Baeninger, 1996) ${ }^{23}$.

Tal planejamento urbano influenciou a organização espacial de modo que a partir de 1950 a urbanização em Campinas se caracteriza pela segregação nos moldes centro-periferia. A valorização imobiliária do centro expulsou os mais pobres para áreas mais periféricas, segundo os autores, com a sanção do poder público, seja pela aprovação dos loteamentos, seja pelo provimento mínimo de infra-estrutura urbana e normas urbanísticas. Cunha et al. (2006) identificam como padrão de crescimento físico da cidade os loteamentos em áreas distantes onde havia pequenas propriedades de produção de algodão, gerando áreas intermediárias vazias e horizontalização com grande especulação imobiliária, principalmente na direção sul e sudoeste de Campinas, próximo a recém pavimentada via Anhanguera. Segundo Baeninger (1996, p. 49):

Dava-se início a um novo processo de crescimento urbano, com um padrão definido por espaços vazios à espera de valorização, verticalização das áreas já urbanizadas e, posteriormente, o surgimento de novos bairros e loteamentos (cada vez mais distantes) para as classes de mais baixa renda.

De acordo com Caiado et al. (2002), é possível identificar dois períodos nos quais se formam duas periferias na cidade. O primeiro vai até 1959 , quando se instituí o

\footnotetext{
${ }^{22}$ Baeninger (1996) faz um estudo detalhado sobre os aspectos da migração para a cidade, captando um longo período histórico. Apresenta a composição da população de Campinas com destaque para a população migrante, atenta para as mudanças espaciais que essa população protagonizou na cidade ao longo de sua história e apresentando o problemático tratamento que ela recebe. É relevante como a autora ressalta o lugar ocupado pelo migrante como parte dos processos de "periferização" e sofrendo discriminação.

${ }^{23}$ Caiado e Pires (2006) destacam a "invejável infra-estrutura" de Campinas, principalmente em termos de circulação em relação às cidades vizinhas e mesmo cidades interioranas em geral, contando com rodovias, ferrovias, aeroportos e gasoduto.
} 
Código de Obras e Urbanismo ${ }^{24}$ e que impulsiona a compra de lotes pela classe média com esperança de valorização econômica.

A segunda periferia se forma entre 1965 e 1979 com a construção de conjuntos habitacionais financiados pelo Sistema Financeiro da Habitação - SFH "em áreas distantes da área urbanizada e abertura de loteamentos populares com pouca ou nenhuma infra-estrutura" (Caiado et al., 2002, p. 125). Segundo os autores, unidades construídas pela Cohab-Campinas entre 1965-74 e entregues até 1978 faziam parte da malha urbana, ainda que na franja periférica e com vazios espaciais intermediários. A partir de 1974 os conjuntos vão sendo construídos cada vez mais distantes da malha urbana consolidada.

Campinas segue sua expansão urbana e, a partir dos anos 1960, surgem as primeiras favelas e cortiços na cidade, como resultado dos investimentos governamentais que tomaram a cidade como eixo de expansão industrial do estado, agora com o intuito de desconcentração industrial da capital, acentuando o processo de interiorização. A construção de favelas e cortiços era a solução habitacional para os imigrantes que continuavam a chegar em grande número na cidade. Como Caiado e Pires (2006) reforçam, na década de 1970, o surgimento de favelas e loteamentos irregulares e clandestinos têm como resultado a extensão da periferia campineira para além dos limites municipais.

Se em 1960 havia 43\% de migrantes em Campinas, entre 1960 e 1970 o saldo migratório foi de 62\% (Cf. Caiado et al, 2002). Acompanhando esses números, o crescimento da população favelada nessa mesma época foi de $1 \%$ para $8 \%$ da população, ou seja, de 3 mil para 45 mil habitantes em número absolutos. E essa tendência de crescimento da população favelada ainda continua alta, pois segundo a Prefeitura Municipal de Campinas ${ }^{25}$ a população favelada tem crescido a taxas anuais muito maiores do que a população total desde 1980.

Nesse contexto, o fortalecimento da relação entre crescimento populacional e pobreza como pauta de discussão administrativa da cidade e identificação da migração como fenômeno caótico e perigoso encontrava duas soluções para o favelamento: a expulsão dos moradores pela polícia e programas de habitação popular (Baeninger, 1996).

\footnotetext{
${ }^{24}$ O Código de Obras e Urbanismo é resultado da Lei no. 1.993/59 que regulamentava, entre outras questões, o parcelamento urbano no município de Campinas (Caiado et al., 2002).

${ }^{25}$ Consultada por Caiado et al. (2002).
} 
De acordo com Zimmermann (1989, apud Baeninger, 1996, p. 59), a CohabCampinas implantada em 1967 contribuiu significativamente para dotar contornos a ocupação urbana de Campinas de modo a espacializar as desigualdades sociais e a presença de migrantes.

A construção de moradias para as classes de renda mais baixas direcionou-se majoritariamente para as proximidades das áreas loteadas esparsamente, no período 1946-54, pelo capital imobiliário loteador (...). Por ser caótica, essa ocupação não interligava os bairros; no final da década de 60 , apenas um décimo da cidade podia ser atingido sem baldeação pelos transportes coletivos. ${ }^{26}$

\subsubsection{Primeiros anos do bairro}

É importante sublinhar a dificuldade de encontrar material sobre a Vila Castelo Branco. O breve histórico de instalação do bairro, a seguir, deve-se às informações presentes na rara bibliografia sobre ele; em jornais da cidade publicados ao longo dos anos; no arquivo da própria Cohab - Campinas e também parte de material que era pertencente a essa e hoje se encontra no arquivo do Centro de Memória da Unicamp CMU. Entretanto, enquanto o primeiro arquivo dispensou boa parte de seu material com a quitação do conjunto pelos adquirentes das casas, o segundo, ainda não sistematizou o material recebido, inviabilizando o acesso a grande parte das informações.

Essa dificuldade, contudo, pôde ser contornada em parte através de entrevistas realizadas com os moradores. Só através da combinação dessas várias fontes de informações é possível conhecer um pouco dos primeiros anos da Vila Castelo Branco, período em que ela estava segregada na periferia urbana de Campinas. E é a partir dessas informações que é traçado o contexto da pesquisa, como veremos a seguir.

A Cohab-Campinas, implantada no final da década de 1960, era o braço municipal do Banco Nacional de Habitação - BNH. Em 1967 essa companhia constrói a Vila Castelo Branco, seu segundo bairro na cidade $^{27}$ como parte do projeto piloto de construção de moradias populares por essa política habitacional. Esse projeto tinha

\footnotetext{
${ }^{26}$ Zimmermann, G. "O Município o sistema tributário: os municípios paulistas e o caso de Campinas”. In: A interiorização do desenvolvimento econômico no Estado de São Paulo (1920-1980), Fundação SEADE, São Paulo, v.1, n. 3, 1989, p. 128.

${ }^{27}$ O primeiro conjunto da Cohab-Campinas foi a Vila Rica.
} 
como preocupação redirecionar a população que habitava os cortiços e as primeiras favelas que se formavam, questão emergente na cidade devido às dinâmicas urbanas do processo de interiorização industrial, conforme vimos acima.

Apesar dessa ênfase do programa habitacional, a solução recorrente para esses problemas de moradia foi a construção de bairros populares em longínquas periferias. Segundo Baeninger (1996), a Cohab "contribuiu significativamente para dotar de novos contornos a ocupação urbana de Campinas" (Baeninger, 1996, p. 59). Tanto a política habitacional praticada, quanto o mercado imobiliário da época, incrementavam um modelo de organização espacial das cidades que destinava a periferia para os mais pobres, seguindo o padrão centro-periferia já exposto anteriormente. A partir dessa premissa, a Vila Castelo Branco foi construída distante da mancha urbana e com várias carências de infra-estrutura.

De acordo com dados consultados na própria Cohab-Campinas, a distância do bairro ao centro da cidade é de $5 \mathrm{~km}$ e $300 \mathrm{~m}$. No entanto, o isolamento que essa distância em quilômetros significava para os moradores pode ser entendido através da dificuldade de locomoção sentida por eles. Isso em parte pode ser ilustrado tanto pela inexistência de linha de ônibus municipal que percorresse o bairro e o ligasse as demais áreas da cidade, quanto pela precariedade das vias de acesso.

Segundo Gonçalves (2002), o asfalto demorou para ser implantado e, nas entrevistas realizadas, os moradores citaram a existência de um único acesso que ligava o bairro à cidade através de uma pequena ponte, a qual não tinha capacidade para suportar o peso de ônibus ou caminhões. A própria fala dos moradores - ligar o bairro à cidade - demonstra a percepção da separação da Vila Castelo Branco, a ponto de muitos ressaltarem suas características mais rurais que urbanas, inclusive pelo fato do terreno se situar próximo a fazendas, pedreiras, mina de água, pasto e granja ${ }^{28}$.

Vale lembrar a observação de Marques (2005) sobre a inexistência de parâmetros para calcular o que seria um bairro distante ${ }^{29}$. No entanto, a dimensão de distância aqui pretendida pode ser suficientemente estabelecida pela descrição das

\footnotetext{
${ }^{28}$ É muito comum nas entrevistas o uso de expressões identificando o bairro no "meio do mato", "no brejo", e também a ênfase em como era longe, difícil, sacrificado e "não tinha nada".

${ }_{29}$ Essa é uma discussão que tem inclusive incentivado a elaboração de índices para mensurar a segregação, principalmente devido às mudanças que a existência de dinâmicas de segregação em contextos de proximidade social tem colocado para as análises. Ver a esse respeito Bichir (2006), Sabatini (2004) e Torres (2004). No entanto, a demonstração do isolamento como considerada aqui estaria mais nítida por outros processos, dispensando por ora uma mensuração mais apurada.
} 
precárias condições urbanas, somada a dificuldade de locomoção e os processos de organização espacial da cidade.

A Vila Castelo Branco ${ }^{30}$ foi concebida em duas fases entre 1967 e 1968 e, segundo informações de relatório da Cohab-Campinas, foram construídas 1.112 unidades habitacionais, sendo que 668 foram entregues na primeira etapa e 444 na segunda.

As casas eram germinadas e tinham de um a três dormitórios, além de sala, cozinha e banheiro, com área média de construção de $23 \mathrm{~m} 2$ e sem portas internas. Por fora, todas as casas eram cercadas por um muro baixo, com jardins na frente, uma árvore de vegetal nobre e uma área para possível expansão da casa (Diário do Povo, 1.8.1967 e Gonçalves, 2002).

O critério de seleção dos adquirentes considerava primeiramente o rendimento familiar que estivesse na faixa entre um e cinco salários mínimos, segundo documentos da Cohab-Campinas. Outro item de consideração era o tamanho das famílias, dando prioridade para famílias numerosas e principalmente com crianças. De acordo com as entrevistas, os interessados em adquirir uma casa pelo sistema fizeram a inscrição num posto de seleção onde muitos passaram a noite na fila para garantir sua vaga. Após a inscrição, uma assistente social visitou o local de moradia original dos entrevistados, fazendo uma avaliação socioeconômica das famílias e a partir desses dados as pessoas conseguiam ou não a chave da casa.

Entretanto, moradores do bairro e mesmo funcionários da Cohab - Campinas informaram sobre a interferência de políticos e funcionários da companhia na concessão da casa para algumas pessoas. Segundo Gonçalves (2002) isso ocorreu porque sobraram casas no bairro. Apesar disso, mesmo nessas situações de favorecimento, não há indicação de rompimento da seleção por renda.

A população que compôs o bairro era em sua maioria constituída por operários, funcionários públicos, domésticas e metalúrgicos, que moravam anteriormente em outros bairros onde também havia relativa concentração de população pobre, mas que eram mais próximos ao centro da cidade (Antunes, 2006). Contudo, em muitos casos as situações de moradia anteriores eram tremendamente precárias, seja pela inadequação física devido ao tamanho da família, seja porque muitos moravam de favor junto com

\footnotetext{
${ }^{30}$ Inicialmente, o nome do bairro era Conjunto Habitacional Vila Bela. A alteração do nome ocorreu em homenagem ao ex-presidente Marechal Humberto de Alencar Castelo Branco, morto em um acidente de avião na época de inauguração do bairro. Entretanto, apesar da mudança oficial, muitos moradores ainda o chamam de Vila Bela, fazendo questão do nome.
} 
outro núcleo familiar, seja pela necessidade de constante mudança e também pelo alto custo do aluguel. De forma que a transição dos antigos locais de moradia, próximos ao trabalho, para a Vila Castelo Branco, na periferia da cidade e com suas dificuldades estruturais, apresentava a vantagem da aquisição de casa própria, como argumentaram os moradores entrevistados e também Antunes (2006).

Segundo reportagem da época da inauguração ${ }^{31}$ o bairro tinha água, luz pública e domiciliar e rede de esgoto, faltando apenas a pavimentação das ruas. Porém, os entrevistados por Gonçalves (2002) afirmam que apesar das casas terem encanamentos e fiação elétrica, não havia infra-estrutura pública de fornecimento desses serviços, que eram melhoramentos públicos de responsabilidade da Prefeitura Municipal, segundo a reportagem citada acima. Além disso, algumas construções de uso comum não tinham sido finalizadas, como, por exemplo, praças, posto policial e posto de saúde. A falta de asfalto, conseqüente falta de ônibus e a distância do bairro ao centro da cidade, são sempre citadas pelos moradores ${ }^{32}$ como as grandes dificuldades iniciais.

Vale frisar que a descrição das condições iniciais de ausência e/ou precariedade de serviços e equipamentos públicos, concentração de população pobre e isolamento espacial de locais com melhores condições urbanas se encaixa na caracterização das periferias urbanas segregadas, como vimos no primeiro capítulo. É a partir desses elementos que entendemos a segregação da Vila Castelo Branco nos seus primeiros anos.

Nesse período há uma coincidência empírica entre segregação espacial e periferias urbanas que acumula qualidades próprias ao tipo de segregação observado na Vila Castelo Branco. Essas características vão além da dimensão da concentração da população homogênea em espaço restrito da cidade. A essa condição básica da segregação agregam-se a somatória de carências estruturais do espaço e o isolamento dado pelas dificuldades de locomoção sentidas pela população. Nesse contexto, o fato da homogeneidade tratada ser a baixa condição socioeconômica só agrava os efeitos que essas características imprimem, uma vez que os custos de acesso aos bens ausentes no bairro podem se tornar barreiras impeditivas a esses bens.

\footnotetext{
31 "Vila 'Presidente Castelo Branco' núcleo residencial foi inaugurado". Diário do Povo, Campinas, 06 de agosto de 1967. Apud Gonçalves, 2002, p. 102.

${ }^{32}$ Tanto pelos entrevistados no âmbito desta pesquisa, quanto por Antunes (2006) e por Gonçalves (2002).
} 


\subsubsection{Novas periferias em Campinas}

Apesar de nosso interesse centrar-se especificamente em um bairro da cidade de Campinas, a escala metropolitana é adotada por muitos estudos recentes sobre a cidade. Essa escolha analítica pela literatura pode ser entendida a partir de três motivos. Primeiro pela forte integração regional dada por atividades econômicas, ainda que com grande destaque para a cidade sede.

Em segundo lugar pelo fato da Região Metropolitana de Campinas ser recém criada, em 2000, momento que evidencia sua condição metropolitana e característica de destaque regional - não só da cidade sede em âmbito metropolitano, mas mesmo extrapolando essa região. Por último, pela dinâmica intrametropolitana que reproduz muitos dos fenômenos espaciais intramunicipais de Campinas, principalmente periferização e concentrações de população homogênea.

A partir da década de 1980 é possível identificar um processo de desconcentração populacional e econômica de Campinas, que estimula parte de seus habitantes a se deslocar para algumas das cidades vizinhas que passam a servir como cidades-dormitórios $^{33}$. Essa situação é incentivada pela busca de locais de moradia mais baratos que os oferecidos na cidade, ao mesmo tempo, que é favorecida pela integração entre os municípios dada pelo sistema rodoviário. Nesse momento, a Região Metropolitana de Campinas começa a se definir cada vez mais e a integração que se delineava desde a década de 1970 se formaliza com a Lei Complementar no. 870 de junho de 2000.

Contudo, se essa dinâmica contribuiu para a conformação da Região Metropolitana, também teve como conseqüência a criação das chamadas "novas periferias" (Cunha e Oliveira, 2001) entre as cidades vizinhas no contexto metropolitano. Baeninger e Gonçalves (2000) apontam que esse processo é evidente através do acompanhamento da migração urbana-urbana metropolitana, que determinam os vetores de crescimento. Isto quer dizer, que desde a década de 1970 é possível identificar a expulsão de população de Campinas para os municípios limítrofes ou próximos.

\footnotetext{
${ }^{33}$ Sumaré e Hortolândia se destacam nessa condição. Por outro lado, alguns municípios se beneficiaram economicamente com a desconcentração de Campinas, desenvolvendo industrialização própria e, inclusive, suas próprias periferias, como Paulínia e Americana. A esse respeito ver Cunha et al, (2006) e Manfredo (2007).
} 
Contudo, chama atenção a composição econômica da população expulsa: pessoas com baixos rendimentos; de forma que o movimento pendular observado expressa a acentuada necessidade de busca por locais de moradia mais baratos. De acordo com as autoras, a tendência de conurbação da região indica mais um fator de configuração espacial seguindo eixos de expansão que vêm se "caracterizando de maneira distinta quanto à absorção da população segundo níveis de renda" (Baeninger e Gonçalves, 2000, p. 30).

Nessa configuração espacial metropolitana é patente a questão da escala da segregação. Isto porque é possível identificar heterogeneidade socioespacial na região como um todo, ao mesmo tempo em que se encontram distintos graus de homogeneidade socioeconômica em pequenas porções (Cunha et al. 2006).

A desigualdade de distribuição da população e dos recursos na cidade ou na Região Metropolitana ressalta a importância de considerar o espaço como categoria analítica para considerações sobre a pobreza, "uma vez que, nas áreas mais segregadas da região, à condição desvantajosa em termos econômicos aliam-se situações de falta ou precariedade dos serviços públicos, infra-estrutura, etc." (Cunha et al, 2006, p. 352).

Contudo, como já foi discutido, o padrão de segregação atualmente não é mais observado na forma de círculos concêntricos, como identificado em outros contextos e mesmo na cidade de Campinas anteriormente. Da mesma forma que os estudos explorados apontaram diversas mudanças nas periferias contemporâneas, alterando inclusive o padrão de organização espacial, na cidade de Campinas a segregação espacial foi redesenhada. A partir dos anos 1990 Cunha et al. (2006) apontam a existência de um padrão de segregação, tanto na Região Metropolitana de Campinas, como na cidade sede, evidente e delineado em sintonia com o sistema viário principal Via Anhanguera - que separa o centro da periferia sul da cidade.

Se a via Anhanguera pode ser vista como o eixo de concentração populacional de baixa renda, é possível relacionar isso ao papel que desempenhou no crescimento urbano e populacional da cidade, seja trazendo migrantes como mão-de-obra industrial, seja favorecendo a integração regional e metropolitana. De forma que a população que ocupa os locais segregados da cidade é trazida por essa via e os migrantes e mão-deobra menos qualificada que mora nas cidades-dormitório da região se instalam nas suas proximidades, atraídos pelo desenvolvimento industrial e empregos de baixa qualificação. 


\section{Mapa 1 - Localização da Vila Castelo Branco no Município de Campinas}

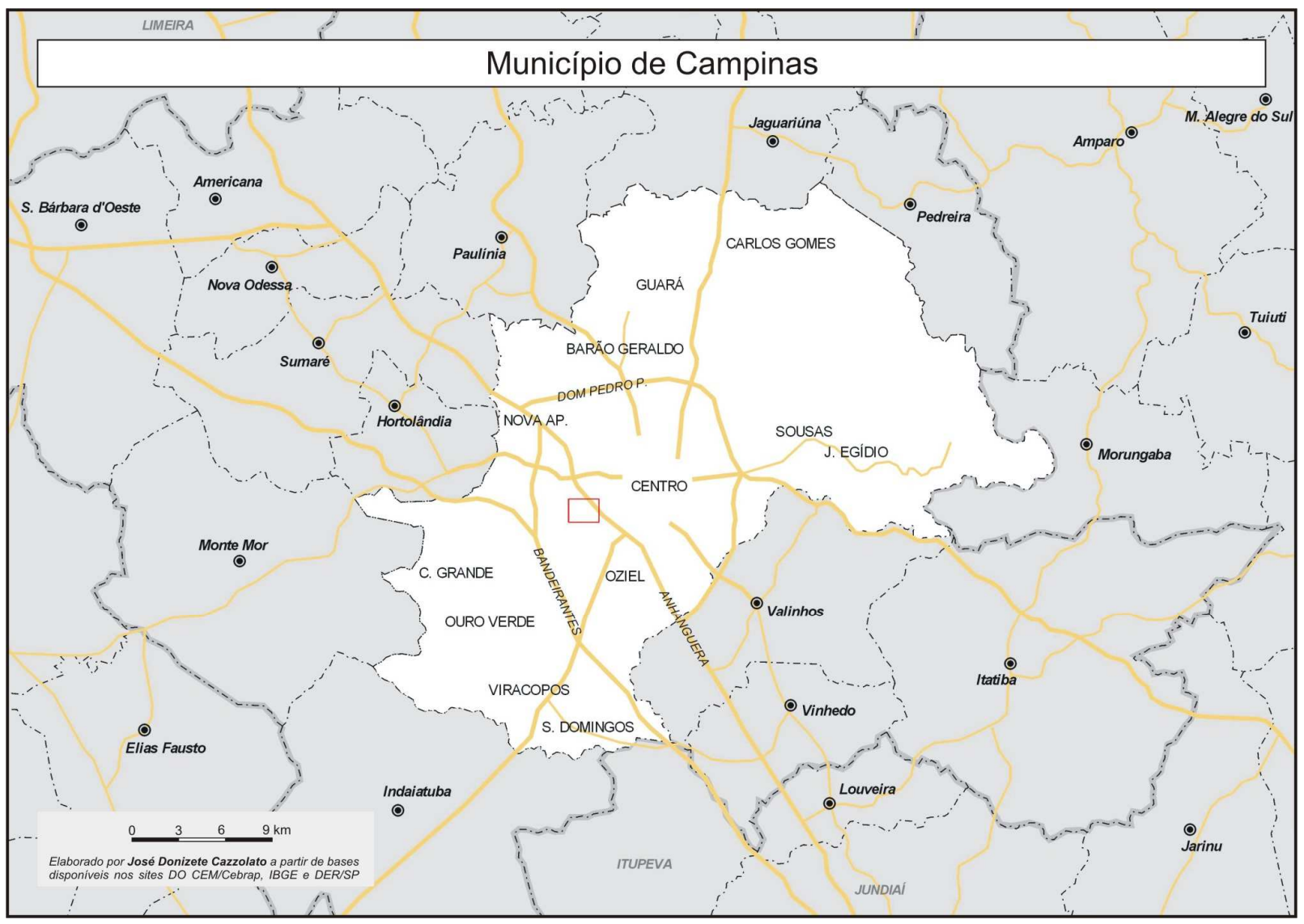

Fonte: Base de dados CEM/Cebrap, IBGE e DER/SP.

Mapa 2 - Setores censitários correspondentes a Vila Castelo Branco e bairros vizinhos.

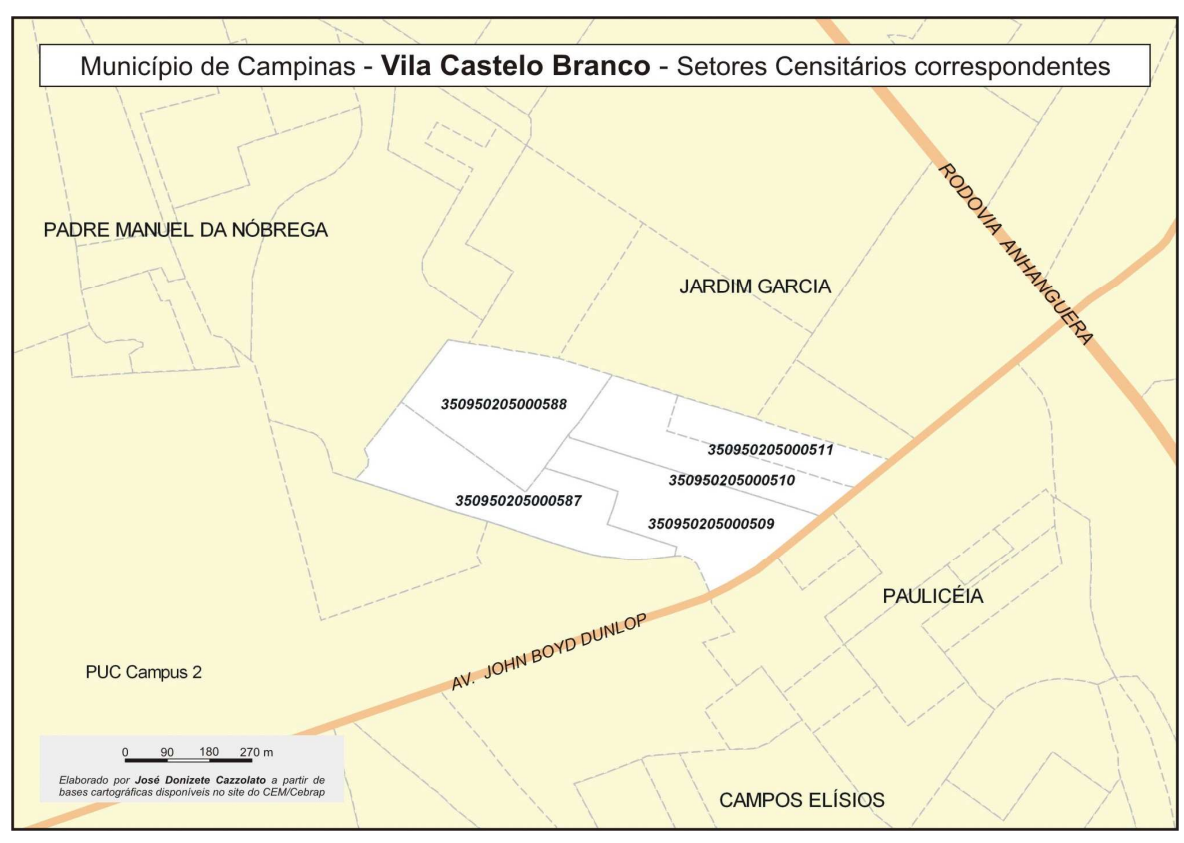

Fonte: Base de dados do CEM/Cebrap 
Mapa 3 - Imagem de satélite com os limites da Vila Castelo Branco.

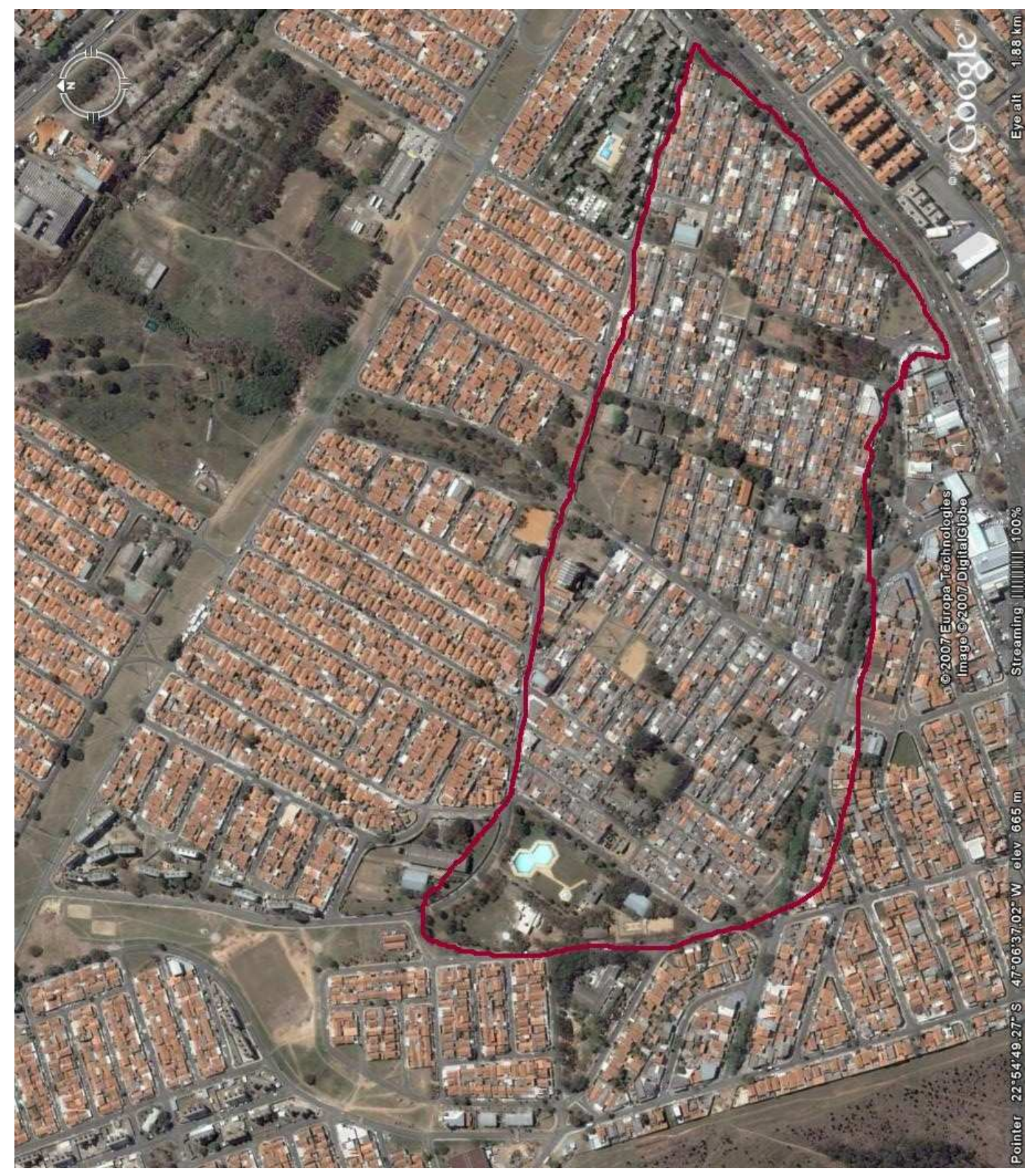

Fonte: Google Earth, consulta em 20/10/2007. 


\section{Mapa 4 - Porcentagem de chefes de domicílio com renda mensal maior que 10 salários mínimos. Região Metropolitana de Campinas, 1991 e 2000.}

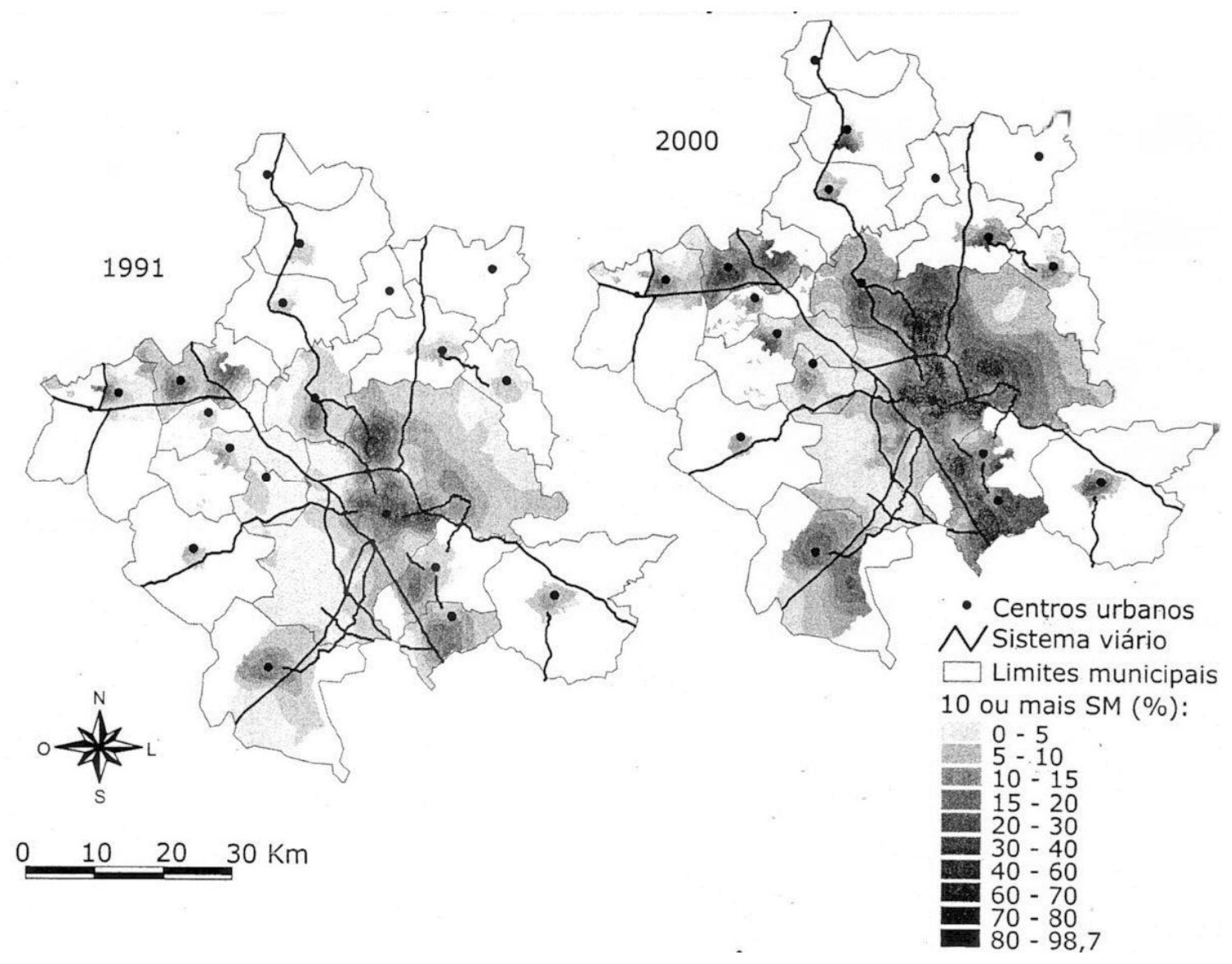

Fonte: Cunha et al., 2006, p. 354.

No primeiro mapa, podemos identificar a Via Anhanguera cortando toda a cidade e a Vila Castelo Branco destacada pelo quadrado em vermelho. É interessante notar que o crescimento da cidade a sudoeste do bairro estudado é bastante recente.

O último mapa presente em Cunha et al. (2006), ilustra o argumento sobre o novo padrão de segregação na cidade de Campinas e em sua região metropolitana. Esses autores designam tal padrão como "cordilheira da riqueza", ou seja, uma delimitação da cidade que acompanha o recorte que a Via Anhanguera faz entre leste e oeste. Tal padrão considera que à leste há concentração de famílias menores, mais ricas, morando em domicílios com melhor infra-estrutura e com rede de serviços de melhor qualidade ${ }^{34}$ do que à oeste. Cunha et al. (2006) afirmam que a "cordilheira da riqueza" é a expressão

\footnotetext{
${ }^{34}$ Áreas mais escuras dos mapas.
} 
do modelo centro-periferia em outros moldes, pois, apesar do novo desenho, poderia se observar a concentração espacial com fortes distinções socioeconômicas.

Se tomarmos como referência essa marcada distinção socioespacial da cidade de Campinas, localizamos a Vila Castelo Branco à oeste da "cordilheira da riqueza", ou seja, região onde se concentra população de baixa renda e local de crescimento urbano em condições precárias e de grande adensamento populacional. Ainda que o bairro tenha sido construído a partir de política pública e tenha se consolidado ao longo dos anos, a região na qual se localiza tem sido destino de muitas ocupações e construção de sub-moradias de população de baixa renda, com infra-estrutura urbana precária, mantendo o bairro numa região pouco favorecida da cidade.

\subsubsection{O bairro hoje}

De forma semelhante a encontrada na bibliografia em outros contextos, o poder público realizou muitas melhorias na oferta de infra-estrutura e serviços no bairro, tanto através de políticas adotadas pelo Estado, como devido às reivindicações dos moradores que se organizaram em suas associações comunitárias ${ }^{35}$.

Com essas melhorias e com a expansão da cidade integrando o bairro, atualmente a Vila Castelo Branco não apresenta as mesmas condições de precariedade de infra-estrutura e serviços públicos de seus primeiros anos. De forma que a reconsideração dos modelos analíticos sobre as periferias urbanas proposta pela bibliografia abarca as mudanças ocorridas na Vila Castelo Branco.

Além dos investimentos realizados no bairro, a questão da integração urbana, merece atenção. Segundo as entrevistas realizadas, no primeiro momento a via de acesso ao bairro era muito precária, tanto por não ser asfaltada, quanto pelas próprias dimensões que impediam o trânsito de caminhões e ônibus. Desse modo, a pavimentação da avenida John Boyd Dunlop foi um marco da comunicação da Vila Castelo Branco com a cidade e mesmo da possibilidade de expansão desta na direção do bairro. Atualmente, os moradores atestam a existência de muitas linhas de ônibus servindo o bairro e como hoje se têm tudo que precisam lá, ficando patente como as restrições anteriores foram superadas.

\footnotetext{
${ }^{35}$ Ver sobre essas organizações em Antunes (2006) e Gonçalves (2002).
} 
De acordo com Antunes (2006), com a estruturação da Vila Castelo Branco, outros bairros surgiram no seu entorno, como o Jardim Garcia, Jardim Londres, Vila Padre Manuel da Nóbrega e Jardim Paulicéia. Dentre esses bairros, outros dois foram construídos pela Cohab - Campinas: o Jardim Garcia em 1975 e a Vila Padre Manuel da Nóbrega em $1980^{36}$. Quanto aos demais, não foi possível identificar a data de construção de casas com precisão, pois pelo fato de serem bairros espontâneos há somente o registro da data de aprovação do loteamento, muito anterior a sua ocupação.

Outro elemento de destaque nesse processo foi a instalação do Hospital e Maternidade Celso Pierro, que em 1977 foi adquirido pela Pontifícia Universidade Católica - PUC. No ano seguinte, com a construção de novos prédios em torno do hospital, consolida-se o Campus II dessa universidade. Esse fato contribuiu significativamente para a atração de recursos para a região e também pelo atendimento que o hospital passou a oferecer, conjuntamente com o auxílio que os alunos dos $\operatorname{cursos}^{37}$ dessa universidade passou a prestar para a população dos bairros ao redor.

No que diz respeito à concentração de população homogênea quanto aos rendimentos, os moradores da Vila Castelo Branco não sofreram alterações nesse quesito. Como veremos a seguir nos dados gerais do bairro, a média de renda da população hoje é de três salários mínimos, caracterizando de forma geral uma baixa renda.

Se a integração da Vila Castelo Branco é sentida pouco a pouco pelos seus moradores justamente por se tratar de um processo alinhavado por diversos fatores e atores, isso dificulta a identificação de apenas um elemento detonador da integração para ser tomado como marco. Mas se levarmos em conta esses elementos ressaltados e as considerações da bibliografia sobre as mudanças ocorridas na década de 1980 consideramos que em meados dessa década a Vila Castelo Branco altera sua condição espacial.

De todo modo, entender melhor o processo de integração do bairro, processo esse contrário a segregação, parece ser um elemento relevante para contribuir nos estudos sobre a segregação e que merece aprofundamento. De modo complementar, é

\footnotetext{
${ }^{36}$ Data do habite-se segundo consulta realizada na Secretaria de Planejamento e Meio Ambiente SEPLAMA da Prefeitura Municipal de Campinas.

${ }^{37}$ Esse campus da PUC é conhecido como "Cidade da Saúde", devido a concentração de cursos da área de saúde e o próprio Hospital e Maternidade Celso Pierro. Muitos atendimentos são prestados aos moradores dos bairros vizinhos, devido ao convênio deste com o Sistema Único de Saúde (SUS). Ver mais a esse respeito no site da própria universidade, http://www.puc-campinas.edu.br.
} 
interessante perceber de que forma se dá a alteração das redes nesse processo ainda pouco estudado, o que será realizado no capítulo três.

Como vimos, Campinas sofreu as modificações pelas quais passaram as cidades brasileiras nos últimos anos que tem requerido reconsiderações das abordagens teóricas sobre os padrões de segregação espacial e periferias urbanas. Do mesmo modo que a Vila Castelo Branco ilustrava esses padrões anteriores, as transformações destacadas pela literatura também tiveram reflexo nesse bairro.

Nesse sentido é importante uma observação sobre as alterações do entendimento da segregação em si e das condições em que se encontram o bairro atualmente. Isto porque o bairro passou por um processo de integração espacial aliado a investimentos em infra-estrutura e aumento das possibilidades de acesso de sua população, também deixando de ser localizado na periferia devido à expansão da mancha urbana que o integrou.

Apesar da proliferação de estudos sobre o tema da segregação, pouco se sabe sobre o processo de incorporação das áreas segregadas, o que fica evidente pela ausência de um termo que dê conta dessa dinâmica espacial com o mesmo peso que segregação consegue imprimir ao fenômeno. O que se encontra são estudos que a tratam a partir das situações já modificadas, sem o acompanhamento do processo para caracterizar um local que era segregado antes e que teria deixado de ser. No limite, Marcuse (2004) fala de dessegregação, mas pensando em um contexto muito distinto do proposto aqui, ou seja, o processo de eliminação de barreiras de residentes de um gueto.

De fato, mudanças foram observadas na Vila Castelo Branco de forma que ela não se caracteriza mais como periferia urbana segregada como acontecia nos seus primeiros anos. Entretanto, dada a complexificação dessas categorias no contexto atual, fica difícil encaixar o bairro nessas denominações ou em outras quaisquer. Poderia-se perguntar se o bairro realmente deixou de ser segregado ou se sua segregação estaria se expressando em uma nova escala.

Segundo a definição que temos utilizado de segregação, esta é constituída por dois elementos: a existência de um espaço separado por algum marco (distância, muros ou mesmo alguma barreira simbólica ou legal) e pelo fato do grupo que o compõe ser homogêneo. A distância da mancha urbana associada à concentração de população de baixa renda são as evidências dessa caracterização observada na Vila Castelo Branco nos primeiros anos. 
Infra-estrutura urbana precária e carências de serviços e políticas públicas são outras características que muitas vezes se associam ao fenômeno da segregação, mas que não fazem parte de sua conceituação. No entanto, são elementos que compunham o cenário das periferias urbanas e do bairro em questão.

É evidente a transformação espacial pela qual passou a Vila Castelo Branco, mas o fato de estar separada ou integrada espacialmente não serviria mais para designála como segregada nem como periférica. Da mesma forma que a existência de boa infraestrutura não a descaracterizaria como periferia urbana por si só. Como vimos acima, essas não são mais qualidades exclusivas de espaços segregados.

Com essas considerações em mente, o estudo do bairro recuperou a marcante transformação espacial pela qual ele passou para pensar os efeitos que essas transformações tiveram sobre as redes dos seus moradores. Considerou-se que essas alterações em si constituíram importante fator de influência sobre as redes sociais dos moradores da Vila Castelo Branco, como veremos na apresentação dos resultados nos próximos capítulos.

\subsection{Quem são os entrevistados e dados gerais sobre o bairro}

Como as informações que percorrem todo o trabalho dependem em grande parte de material coletado através de entrevistas com moradores do bairro, vale uma rápida apresentação desses para conhecimento dos sujeitos da pesquisa.

Foram realizadas 30 entrevistas com moradores da Vila Castelo Branco. Avaliou-se que esse número seria suficientemente capaz de apresentar resultados pertinentes, considerando o tempo disponível para a realização das entrevistas, processamento e análise dos dados coletados. Isso porque foi preciso contar com a disponibilidade das pessoas em responder às questões, o que exigia dedicação de pelo menos uma hora, sendo que por vezes foi preciso marcar um retorno para finalizar a entrevista. Assim, imperaram duas questões: conseguir essa disponibilidade a partir de contatos imprevistos em muitos casos e alcançar um número abrangente o suficiente para que os resultados tivessem a maior expressão quantitativa possível. Além disso, era necessário que os entrevistados fossem residentes no bairro desde antes da mudança espacial, mas que também não fossem idosos demais. 
Outro fator que colabora também na abrangência dos resultados alcançados é a própria comparação empreendida entre as redes dos dois períodos multiplicando as trinta redes iniciais em duas vezes e permitindo confrontos entre redes da mesma pessoa. Além disso, há a possibilidade de cotejo com pesquisa similar desenvolvida por Marques (2007 e no prelo). Apesar do contexto daquele ser a cidade de São Paulo, o compartilhamento da mesma metodologia forneceu referências para a condução da presente pesquisa, bem como agregaram elementos para traçar paralelos na análise desenvolvida. De modo que foram realizados dois níveis de comparações: entre os tempos de cada rede e entre casos.

A opção por entrevistar os moradores que passaram pela mudança espacial, por um lado poderia produzir um viés da passagem do tempo em suas redes sobre os resultados da pesquisa, mas por outro, permitia a comparação da rede da mesma pessoa entre os tempos. Constatado esse trade-off, considerou-se interessante o acompanhamento da mesma rede nos dois períodos devido a possibilidade de ressaltar a mudança correlacionada às configurações do bairro, além da factibilidade de recuperar as redes do primeiro período. De fato, o levantamento dos dados desse primeiro momento do bairro só seria possível atualmente através da memória de seus moradores mais antigos e o processo de captação da rede no passado pareceu mais producente quando esta rede é elaborada como rede atual ${ }^{38}$.

O contato com os entrevistados estabeleceu-se a partir de três formas: através de contatos anteriores com moradores conhecidos durante a pesquisa de iniciação científica $^{39}$; por indicações de agentes de saúde do Posto de Saúde Integração que atende o bairro e outros ao seu redor; e também por abordagem direta nas casas ou lugares públicos do bairro.

O critério de seleção dos entrevistados foi o tempo de moradia no bairro, ou seja, pessoas que moram na Vila Castelo Branco desde pelo menos a década de 1980 e tenham vivido as mudanças espaciais, sendo que a grande maioria dos entrevistados mora desde a época de construção das casas. Desse modo, esse critério acabou interferindo na faixa de idade dos entrevistados que variou dos 51 aos 81 anos.

\footnotetext{
${ }^{38}$ Os estudos sobre história de vida ressaltam que toda elaboração do passado se faz no presente (Bosi, 1979). Desse modo, a produção da rede no presente e a construção da rede do primeiro momento através da atual, respeitam a lógica da elaboração da narrativa e reconstrução de um momento passado, facilitando para o entrevistado e avalizando a rede construída.

39 "História Oral: prática de pesquisa-ação para levantamento de memória de bairro". Essa pesquisa foi realizada com o apoio da FAPESP e integrada ao projeto "Memória, Qualidade de Vida e Cidadania: História dos Bairros Populares de Campinas", do Centro de Memória da Unicamp - CMU.
} 
Um reflexo dessa faixa de idade encontrada entre o perfil dos entrevistados diz respeito à ocupação profissional. A maioria (vinte e um entrevistados, ou 70\%) é aposentada ou pensionista, sendo que quatro são donas de casa $(13,3 \%)$ e apenas cinco $(16,7 \%)$ ainda exercem alguma atividade remunerada.

Com relação ao sexo, houve maior disponibilidade das mulheres em participar da pesquisa, sendo que 23 dos entrevistados são mulheres e apenas 7 são homens. Sobre a situação conjugal, 13 entrevistados são viúvos, 11 são casados ou moram com atual parceiro, três são solteiros e três são divorciados.

A maioria é natural de Campinas (dezesseis entrevistados, ou 53,33\%). Entre os migrantes, oito são de outras cidades do próprio estado de São Paulo, cinco são de Minas Gerais e um de Sergipe.

Quanto à renda, um dos entrevistados disse receber menos que um salário mínimo $^{40}$. Outros quatro afirmaram ganhar entre 1 e 2 salários mínimos; nove ficaram na faixa entre 2 e 3 ; três até 5 . Nove pessoas disseram ter rendimentos maiores que 3 salários mínimos, sem maiores especificações, e quatro não quiseram fornecer a informação, de modo que não é possível calcular uma média de renda entre os entrevistados.

A média de escolaridade entre os trinta entrevistados é de 5,52 anos de estudo, sendo que grande parte estudou apenas quatro anos $(43 \%$ dos casos, ou treze entrevistados). Cinco casos ou $17 \%$ se encontram na faixa da maior escolaridade encontrada que foi de onze anos, correspondendo ao ensino médio. Dois entrevistados não estudaram em escolas formais e um não respondeu à questão.

Além desses trinta entrevistados, outros sete responderam ao questionário e deram informações sobre a vida no bairro, contudo não foi possível completar a entrevista com a elaboração de suas redes devido à falta de disponibilidade desses entrevistados para participar dessa etapa da pesquisa. Dessa forma, optou-se por aproveitar as informações que foram coletadas, ainda que essas não possam ser analisadas na totalidade da proposta do trabalho. Para uma caracterização rápida, dentre esses entrevistados quatro são homens e três são mulheres; a variação da idade é a mesma; três são viúvos, três divorciados e um casado; quatro aposentados e três ainda trabalham e todos são naturais de Campinas.

\footnotetext{
${ }^{40} \mathrm{O}$ valor do salário mínimo é de $\mathrm{R} \$ 415,00$ em 2008. Veremos mais dados de renda a seguir.
} 
A seguir serão apresentados alguns dados gerais sobre o bairro para melhor entendimento de suas características e comparação com o perfil dos entrevistados.

A população da Vila Castelo Branco em 2000 era de 4.355 pessoas, segundo dados do Censo 2000 do IBGE. Esses mesmos dados indicam a existência de 1.271 domicílios particulares permanentes mostrando que outras casas foram construídas posteriormente fora do planejamento da Cohab-Campinas, já que esta teria construído apenas 1.112 unidades.

Uma observação a ser feita a respeito dos dados disponíveis é que de forma geral as informações com base territorial encontrados na bibliografia sobre Campinas não privilegiam os contornos dos bairros em sua grande maioria ${ }^{41}$. Grande parte dos estudos consultados e mesmo dados de órgãos municipais utilizam diferentes unidades territoriais dificultando a comparação entre os dados fornecidos ${ }^{42}$.

No entanto, apesar dessa dificuldade de comparação, os limites formais do bairro coincidem com o de cinco setores censitários do Censo de 2000 do IBGE, sendo possível a obtenção de algumas informações a partir dessa unidade analítica. Para os outros censos foi necessária a compatibilização com as constantes reformulações de unidade analítica do período em foco ${ }^{43}$.

Com relação a renda, apesar de não ser possível recuperar esse dado para a década de 1970 e 1980 através dos censos, podemos adotar a informação de acordo com o critério de seleção dos moradores da Vila Castelo Branco pela Cohab-Campinas. Ou seja, a faixa entre um e cinco salários mínimos ${ }^{44}$ adotada para a seleção dos adquirentes.

De acordo com o Censo do IBGE de 1991, a maior parte dos moradores do bairro, ou seja, 57,7\% tinham uma renda que variava entre 1 e 3 salários mínimos. Considerando uma faixa maior, temos que $78,96 \%$ dos moradores tinham rendas que

\footnotetext{
${ }^{41}$ Este problema foi identificado por Cazollato, 2005. Segundo ele, dificilmente os bairros integram a estrutura territorial do IBGE, a principal fonte de dados censitários utilizada em pesquisas. Isso só acontece "quando são definidos e delimitados por instrumento legal, estadual ou municipal", de forma que cabe aos municípios a faculdade de criar bairros e a partir dessa criação que os bairros passam a se constituir como unidade de coleta de informações. No entanto, de acordo com esse autor, nem todos os municípios regulamentam essa divisão que acaba sendo aleatória e dificulta a padronização dos dados dessa forma para o IBGE.

${ }^{42}$ Como exemplos, temos as Administrações Regionais - AR; Macrozonas; Unidades Territoriais Básicas - UTB; áreas de planejamento - AP; áreas de ponderação e os setores censitários do IBGE.

${ }^{43}$ Agradeço enormemente o auxílio prestado por Alberto Augusto Eichman Jakob, pesquisador do Núcleo de estudos da População - NEPO/UNICAMP, no tratamento desses dados.

${ }^{44}$ O salário mínimo em 1970 era de $\mathrm{NCr} \$ 187,20$.
} 
iam de 1 até 5 salários mínimos ${ }^{45}$. Em 2000, a renda média dessa população era de 3,83 salários mínimos ${ }^{46}$, calculada com base nos dados do Censo 2000.

Segundo esses dados a média de renda parece ter sido mantida relativamente próxima da usada para a seleção dos adquirentes das casas pela Cohab-Campinas. Do mesmo modo, apesar de não podermos calcular uma média de renda dos entrevistados pela pesquisa, as informações mais precisas que obtivemos nesse quesito são bastante compatíveis com a média encontrada ao longo dos anos. Ou seja, dentre os entrevistados que responderam pontualmente essa questão, grande parte se encaixa na faixa entre 1 e 5 salários mínimos ${ }^{47}$.

Com relação aos estudos, só foi possível obter as informações para a população do bairro no Censo de 1991. Segundo esse censo a maioria dos moradores da Vila Castelo Branco tem quatro anos de escolaridade, seguida daqueles que não tem instrução e em terceiro lugar estão as pessoas com três anos de estudo.

A média de instrução dentre os moradores entrevistados é de 5,52 anos de estudo e pode-se apontar que nesse grupo são poucos os que não estudaram, diferindo dos dados obtidos através do IBGE.

A seguir apresento uma tabela com a composição etária da população da Vila Castelo Branco de acordo com dados do Censo 2000.

Tabela 1 - Composição etária da população da Vila Castelo Branco

\begin{tabular}{|l|l|l|l|l|l|l|l|l|l|}
\hline Faixa etária & 0 a 9 & 10 a 19 & 20 a 29 & 30 a 39 & 40 a 49 & 50 a 59 & 60 a 69 & 70 a 79 & $\begin{array}{l}80 \text { ou } \\
+\end{array}$ \\
\hline Total & 581 & 732 & 580 & 719 & 567 & 342 & 534 & 234 & 66 \\
\hline Percentual & 13,35 & 16,80 & 13,35 & 16,55 & 13 & 7,85 & 12,30 & 5,40 & 1,50 \\
\hline
\end{tabular}

Fonte: Elaboração própria a partir de dados do Censo 2000 - IBGE.

De acordo com os dados da tabela, percebe-se que a faixa de idade dos entrevistados (de 51 a 81 anos) engloba cerca de $27 \%$ da população do bairro.

\footnotetext{
${ }^{45}$ O valor do salário mínimo de 1991 teve uma variação enorme devido a inflação econômica do período. Em janeiro ele foi registrado com o valor de Cr\$12.325,00 e em dezembro desse mesmo ano era de Cr\$63.000,00. O dado apresentado foi gerado a partir da renda do chefe do domicílio.

${ }^{46} \mathrm{O}$ salário mínimo em 2000 era de $\mathrm{R} \$ 151,00$. Chegou-se a essa média pelo cálculo da renda total dos setores que formam o bairro dividida pela quantidade de domicílios desses setores.

${ }^{47} \mathrm{O}$ valor do salário mínimo em 2008 (época da realização das entrevistas) é de R\$415,00.
} 


\subsection{Redes no bairro}

O fato do contexto desse estudo ser um bairro imprime certas características sobre as redes que nele encontramos que merecem nossa atenção. Ficaram evidentes elementos comuns que perpassam essas redes, o que nos remete a pensar a influência que a circunscrição do bairro como universo de pesquisa exerce sobre os relacionamentos sociais desses indivíduos.

Sobre esse aspecto é importante ressaltar que as redes foram construídas focadas em um indivíduo e abarcando todos os vínculos desse ego ${ }^{48}$, um tipo de rede designada como rede total. Dessa forma, elas se diferem das chamadas redes de comunidade que são constituídas tematicamente (Marques, 2007), abarcando todo o ambiente relacional que cerca um indivíduo no contexto de determinado tema ou em determinado espaço como no caso de comunidades profissionais ou famílias, por exemplo. No entanto, elementos comuns percorreram as redes encontradas, uma vez que o fio condutor da entrevista e a própria escolha dos entrevistados derivam do fato de pertencimento ao bairro, compondo em parte o que chamamos de vizinhança.

A vizinhança corresponde, portanto, a duas dimensões das redes no nosso caso. Primeiramente, compondo o universo de estudo e recorte de referência, mas também, como esfera de sociabilidade para cada ego, esfera essa que está dada para todos os outros indivíduos entrevistados. Isto é, em redes egocentradas recolhidas de forma espalhada por toda a cidade, a esfera da vizinhança de um ego de um bairro qualquer é composta por pessoas, histórias, signos e narrativas, diferentes da esfera de vizinhança de um indivíduo em outro bairro. No entanto, considerando dois sujeitos no mesmo bairro - ou seja, a vizinhança circunscrevendo os indivíduos - suas esferas de sociabilidade de vizinhança e demais elementos constitutivos de suas relações têm contingências dadas pelos relacionamentos no interior deste bairro dado.

Contudo, é necessário sublinhar que, assim como as demais esferas de sociabilidade, a vizinhança é delimitada cognitivamente. De forma que não é mecânica a identificação de moradores de um bairro como vizinhos e de moradores de outros bairros como não sendo vizinhos. Isto é, ela não se delimita imediatamente pelos contornos do bairro, mas pelos vínculos estabelecidos entre as pessoas e os conteúdos veiculados que fazem com que essas relações assumam caráter de vizinhança.

\footnotetext{
${ }^{48}$ Maiores detalhes sobre o procedimento das entrevistas na próxima seção.
} 
Nesse sentido, a discussão sobre a relação imediata entre pertencimento à vizinhança e formação de uma comunidade, como empreendida por Blokland (2003) lança luz a diferenciações dessas dimensões que devem ser mantidas sob foco para a análise dos elementos comuns. Essa autora aponta como as idéias de vizinhança e comunidade foram concebidas como "gêmeos siameses" na sociologia e esclarece que cada uma refere-se a um fenômeno distinto. Dessa forma, seu argumento é que o pertencimento a um bairro popular - indicativo de vizinhança - nem sempre corresponde à existência ou ausência de uma solidariedade entre seus membros, o que de fato constituiria uma comunidade.

Entretanto, podemos adentrar nessa discussão a partir dos aspectos comuns levantados na pesquisa sobre a Vila Castelo Branco. Um dos primeiros exemplos diz respeito a citação coincidente das pessoas na rede. Mesmo considerando as dimensões do bairro e as estratégias de captação das entrevistas atenta para a diversidade na abordagem dos moradores, algumas pessoas apareceram em várias redes. Em alguns casos por serem pessoas que exercem atividade de destaque no bairro ${ }^{49}$ e que, consequentemente, têm muitos contatos no local. No entanto, há outros casos de pessoas sem essa característica de destaque, mas que também apareceram em mais de uma rede. É interessante notar também que a citação de um nó por um ego nem sempre é reciprocamente coincidente, isto é, Maria cita José em sua rede, mas José pode não citar Maria, por exemplo.

Nesse ponto fica evidente como as pessoas da vizinhança estão presentes nas redes dos indivíduos, sem configurar uma rede de comunidade fechada em si, pois apesar da coincidência entre algumas citações, sempre ocorreram nós citados exclusivamente por um único ego. De acordo com Ferrand (2002), a citação de outras

\footnotetext{
${ }^{49}$ Como o coordenador da Casa de Cultura Tainã, o fundador da Escola de Samba Rosas de Prata e a coordenadora do Progen e mesmo pessoas não ligadas atualmente a nenhuma entidade, mas que desenvolvem alguma atividade reconhecida no bairro. A Casa de Cultura Tainã é uma entidade cultural que trabalha principalmente com questões da cultura negra; a Escola de Samba Rosas de Prata é a escola de samba do bairro, fundada oficialmente em 1983, tendo grande destaque no carnaval da cidade nessa época. O Projeto Gente Nova, conhecido como Progen, é uma ONG que desenvolve atividades de educação não- formal com crianças e adolescentes da região da Vila Castelo Branco desde 1984. Os dois primeiros foram entrevistados, no entanto, por problemas de disponibilidade para entrevistas, suas redes foram parcialmente captadas, impedindo sua análise integral. A coordenadora do Progen, por sua vez, por não ser moradora do bairro não foi entrevistada nos moldes estabelecidos pela pesquisa, apesar de contribuir com informações de um modo geral.
} 
pessoas além das coincidentes nas redes (independente do localismo do nó) pode ser observada como característica própria das localidades ${ }^{50}$.

Em relação à história do bairro, é interessante notar como eventos marcantes, principalmente relacionados a construção de espaços institucionais, como o Posto de Saúde, escolas, Igreja Nossa Senhora de Guadalupe e também a fundação da Escola de Samba e a reforma da Praça dos Trabalhadores, são sempre lembrados pelos entrevistados, mas acompanhados de repercussões e significados distintos para cada pessoa. Nesses casos, muitas vezes os comentários variaram de um extremo ao outro, como a Praça dos Trabalhadores, identificada como "uma benção para o bairro", mas também lembrada pejorativamente com o apelido corrente de "pinicão" e local de "desocupados".

Outro fator é a experiência comum de mudança para a Vila Castelo Branco na época de sua construção, com suas especificidades e carências. A lembrança das dificuldades dos primeiros anos é contraposta a uma fala que se repetiu em quase todas as entrevistas, que ressalta como "hoje tem tudo", "agora aqui já é cidade". Essa fala foi constantemente acompanhada por uma lista de serviços e comércio implantados no bairro ou na redondeza: banco, padaria, várias linhas de ônibus, banca de revista, posto de saúde, hospital, lojas, entre outros.

Em estudo sobre a favela de Paraisópolis em São Paulo, Almeida e D’Andrea (2005) se depararam com situação semelhante, ou seja, os moradores desse local também apresentaram lista de benefícios que a moradia nesse bairro lhe proporciona, acompanhada da expressão "aqui tem tudo".

Pode-se pensar como a experiência comum ou o compartilhamento discursivo desta entre os moradores do mesmo bairro pode ter forjado essas identificações entre os diferentes sujeitos. De acordo com Mische e White (1998), as relações sociais são produzidas pelo cruzamento de conjunto de redes e conjunto de histórias, que são constituídas de forma especializada, por domínios de interações discursivas. Se a

\footnotetext{
${ }^{50}$ Em seu estudo das comunidades locais como estruturas meso, Ferrand (2002) tem como objetivo definir que a conectividade interna-externa presente nas redes locais conforma o que ele denomina de "formas de dualidade", sendo esta uma propriedade estrutural das localidades. Para o autor interessa as formas de dualidade ou conectividade, mas dentro de suas formulações é importante como ele ressalta o papel do espaço em relação às possibilidades das redes. No fundo, as questões se assemelham: como o espaço interfere nas redes sociais no caso da Vila Castelo Branco e como redes formadas com algumas restrições conectam o dentro e o fora. A questão chave que orienta a pesquisa de Ferrand (2003) pode ser resumida nas seguintes palavras: "estas distribuições dão informações não sobre as 'localidades' em si mesmas, mas sobre as maneiras em que unidades locais efetuam a intersecção com sistemas relacionais não locais ilimitados" (Ferrand, 2002, p. 6, tradução minha).
} 
interação está sendo travada em torno da experiência cotidiana do bairro, pode-se dizer que as correlações empreendidas dentro do repertório conhecido de cada morador estejam desembocando de forma semelhante entre os indivíduos, justamente devido às redes e domínios nos quais eles estão embebidos.

Como já foi explorado para o caso das esferas de sociabilidade, Mische e White (1998) chamam de network domains ou netdoms determinada disposição de laços de redes ao longo da associação de signos e histórias compondo uma narrativa que se estende pelo tempo. Nesse sentido certa semelhança pode ser traçada com a composição de um netdom entre os moradores do bairro pela coincidência de certos elementos e pela presença de pessoas iguais nas diversas redes. Da mesma forma que a vizinhança se configura tanto como universo de estudo, quanto como esfera de sociabilidade, a semelhança com os netdoms de Mische e White (1998) se demonstra em ambos os aspectos.

A circulação de repertórios ${ }^{51}$ e informações veiculados pelas redes fica evidenciada tanto pela repetição de padrões, como os explorados anteriormente, quanto pelos casos divergentes. Paradigmático nesse sentido é o caso do entrevistado 37, que foi um dos poucos que ao ser perguntado sobre as mudanças na Vila Castelo Branco falou sobre o crescimento do movimento negro, da cultura de forma geral no bairro e não fez a listagem de comércio e serviços instalados na região. A análise de sua resposta em comparação com a parte da rede que foi levantada ${ }^{52}$ demonstra que não apenas sua visão sobre o bairro é distinta como a própria rede de pessoas se distancia das redes captadas de seus vizinhos.

Outro entrevistado que também apresentou repertório variado e divergente do geralmente encontrado entre os moradores da Vila Castelo Branco foi o identificado pelo número 31. Seu histórico relacional de contato com um mundo artístico e intelectual se destoa de grande parte do que foi encontrado entre os moradores do bairro. Salta aqui a evidência dessa distinção na elaboração de sua rede, já que ele citou artistas famosos do samba da mesma forma que citou pessoas próximas, revelando apenas ao final da entrevista que não conhecia pessoalmente tais artistas.

\footnotetext{
51 Entendendo repertórios no sentido mais amplo utilizado por Mische e White (1998). De foram a abarcar tanto os elementos que compõem a comunicação, quanto os conteúdos veiculados e representados (signos).

52 Esse entrevistado foi um dos sete dos quais não foi possível completar a captura da rede nos moldes estabelecidos metodologicamente.
} 
Tais casos destoantes tornam ainda mais evidente a circulação de repertórios pela rede. Isso porque tanto o entrevistado 37 quanto o 31 , circulam em meios distintos dos freqüentados por seus vizinhos, o que acarretou na existência de outros elementos e pessoas nas suas redes.

Além disso, a resposta mais utilizada para a questão sobre as mudanças observadas no bairro pode refletir outros padrões de repertório mais gerais do significado de progresso, pertencimento a uma cidade, crescimento, melhora - palavras utilizadas pelos entrevistados para designar a mudança espacial. Nesse caso, se a padronização do discurso pode expressar uma comunicação ou representação local consolidada sobre as mudanças do bairro, também pode refletir representações mais gerais. Isto é, a fluidez dessa informação no nível local indica tanto uma rede estabelecida de certas convicções (do progresso, da melhora, etc) pelos moradores do bairro que sofreu tais transformações, quanto uma articulação mais generalizada dessas idéias e repertórios (isto é, que extravasa os limites do bairro).

Essa discussão permite problematizar a padronização das respostas pelo lado que concorda com o argumento da partilha de experiências comuns no bairro pela existência de uma rede de relacionamentos nesse local. Mas por outro lado, também explicita como essa rede não está isolada e dialoga com outras redes que podem (na partilha da idéia predominante de progresso) ou não (resposta do entrevistado 37) reproduzir esse discurso padronizado.

A concepção dos moradores sobre a segregação pretendia ser captada em parte através dessa questão que enfocava as mudanças espaciais. Ao menos a intenção era de que no momento que os moradores relatassem as mudanças ocorridas no bairro, seria possível apreender a percepção deles sobre a mudança da segregação, já que esse é o fenômeno de transformação evidente. Contudo, ao invés de obter um relato do processo de integração espacial, a resposta obtida foi uma relação de coisas que significam esse processo para essa população. A ausência de serviços e comércios, bem como a distância são elementos de definição da segregação e o fato da existência desses elementos mostra que o bairro "mudou muito", "melhorou", "progrediu", sendo desnecessária uma narração mais articulada dos significados. Os elementos significantes bastam.

Contudo, a análise das narrativas deve ser entendida no contexto de complementação dos dados ressaltados pelas redes dos moradores da Vila Castelo Branco. A opção metodológica privilegiou a amplitude do número de entrevistas e 
captação das redes para elaboração dos sociogramas em detrimento dessa análise mais apurada da percepção dos moradores sobre a mudança espacial e suas redes sociais. A intenção foi ressaltar as redes sociais e suas estruturas como foco da investigação, sendo esta complementada pelas entrevistas, combinando os elementos presentes em ambas para entender a questão da mudança espacial sobre os relacionamentos sociais na Vila Castelo Branco.

\subsection{Procedimentos e definições de pesquisa}

Dadas as considerações sobre a influência do espaço sobre as redes, as principais perguntas que deverão ser respondidas pela análise das redes dos moradores da Vila Castelo Branco são: houve alteração no tamanho das redes? E quanto à variabilidade da sociabilidade? A quantidade de pessoas de dentro ou de fora do bairro diminuiu ou aumentou?

Deste modo, os sociogramas foram construídos de forma atenta a essas questões com o intuito de observar a relação entre as duas estruturas social e espacial. Para efeitos de comparação, foram considerados dois períodos no tempo de existência do bairro que abarcaram a mudança da condição espacial, como já foi descrita. Nessa seção, alguns procedimentos metodológicos serão detalhados para melhor compreensão dos dados captados e da análise empreendida.

Como já explicitado acima, o tipo de rede utilizado nesse estudo são as chamadas redes totais construídas a partir de entrevistas egocentradas, isto é, perguntando ao indivíduo/ego sobre suas relações. No entanto, para melhor operacionalização dos dados, um limite de duas rodadas de geração de nomes foi estabelecido, seguindo a metodologia desenvolvida por Marques (2007) para pensar redes sociais e pobreza na cidade de São Paulo.

A partir dessas definições, as redes foram construídas da seguinte forma: antes de iniciar a aplicação do questionário gerador de nomes para elaboração da rede, foi realizada uma entrevista sobre o perfil dos entrevistados e informações sobre a vida no bairro, envolvendo também questões sobre atividades nas quais os indivíduos estejam envolvidos. Assim, além de captar informações sobre a Vila Castelo Branco, a intenção era identificar as esferas de sociabilidade de cada ego para conduzir a construção das redes. 
A partir daí utilizou-se o gerador de nomes e para cada esfera de sociabilidade identificada nas relações do ego durante a entrevista foi pedida a citação de três nomes a elas pertencentes, o que recebe o nome de semente. Para cada nome citado na semente, pedi mais outros três que se relacionassem ao primeiro (independente da esfera de sociabilidade dos nomes decorrentes) e isso se repetiu por duas rodadas. Finalizada a citação dos nomes, perguntas sobre alguns atributos dos indivíduos que constituem os nós das redes foram feitas.

Os atributos selecionados foram quatro. O primeiro deles é o localismo que está explicitamente ligado à dimensão espacial das relações, identificando se o nó era de dentro ou fora do bairro estudado. Também captada como atributo, a esfera de sociabilidade do nó fornece informações de como a rede se expande e qual sua variabilidade, postas posteriormente em consideração com as condições espaciais. O terceiro atributo é o sexo dos nós, que não chegou a ser questionado, mas inferido a partir dos nomes dados, sendo explicitado apenas quando houve dúvidas em casos de nomes ambivalentes.

O último atributo refere-se ao tempo do nó na rede. A questão dos dois períodos, chamados de $\mathrm{t} 1 \mathrm{e}$ t2, foi conduzida da seguinte forma: foi estabelecido com o entrevistado um marco temporal em meados da década de 1980, de preferência relacionando a algum evento marcante em sua vida ou com um marco genérico que possibilitou identificar quem entrou antes ou depois desse evento na sua rede. Alguns eventos importantes para os entrevistados inclusive apresentaram relação com as mudanças espaciais. A partir desse atributo foi possível construir duas redes para cada entrevistado para os dois períodos de interesse. Sendo que a rede total captada é a rede atual do indivíduo (t2), onde aparecem nós que estão presentes atualmente e que podem tanto ter entrado no primeiro como no segundo período. Para a elaboração da rede no primeiro período foram retirados os nós com o atributo depois, mantendo apenas os indivíduos que faziam parte da rede antes, no $\mathrm{t}^{53}$.

Se no t2 foram acrescentados os nós conhecidos depois, em alguns casos, no t1 apareceram pessoas que atualmente estão mortas, mas que foram citadas como pertencentes a rede, tendo conseqüências sobre a configuração desta. Neste caso, optouse por deixar esse nó no t1 e sem aparecer no t2, para não correr o risco de se excluir

\footnotetext{
${ }^{53}$ Uma pesquisa que também considerou dois períodos de constituição de redes sociais foi a realizada por Pavez (2006b). Ainda que o procedimento metodológico tenha sido distinto do adotado aqui, o trabalho dessa autora, bem como conversas pessoais, foram importantes auxílios para o estabelecimento da conduta tomada para a investigação da Vila Castelo Branco.
} 
laços que podem ser importantes para essa rede, isto é, os contatos gerados a partir de um contato morto. Esse procedimento foi estabelecido levando-se em conta que a análise recai sobre períodos e não em datas precisas de entrada ou saída dos nós nas redes. O caso dos mortos seriam os únicos casos em que a rede do t1 perde contato em relação à rede do t2, já que não foi captado dados referentes a manutenção ou perda dos vínculos além da dada por essa alteração.

Outro ponto que merece consideração foi a existência de redes nas quais pessoas que entraram no segundo período ligavam nós conhecidos no primeiro tempo. Tal fenômeno não é surpreendente se considerarmos que a organização cognitiva das redes e a citação das pessoas que delas fazem parte dependem mais de fatores como proximidade e identificação, entre outros, do que de uma ordenação cronológica do conhecimento das pessoas. Quando isto aconteceu optou-se por manter os nós soltos na rede desde que houvesse vínculos entre eles, como que formando uma ou mais redes à parte da ligada diretamente ao ego. Tal procedimento foi adotado por se entender que os vínculos existiam e compunham uma parte dos relacionamentos do ego, ainda que sem a ligação elaborada atualmente. No entanto, em casos de nós sem qualquer vinculação suprimiu-se o nó, entendendo que um nó solto não comporia a rede e poderia interferir nas análises sem efeito relacional importante para o ego ${ }^{54}$.

Ainda sobre a questão dos períodos, outro fator importante que deve ser considerado na construção das redes diz respeito à construção de redes em dois tempos tão distantes entre si, podendo chegar a 40 anos. Dado que o interesse dessa pesquisa é verificar qual a influência que a mudança de um espaço segregado à não segregado pode ter sobre as redes das pessoas, a reconstrução das relações sociais esteve sujeita a rememoração e outros elementos poderiam ter influenciando o tamanho da rede e a variabilidade da sociabilidade, sendo que o principal deles nesse caso é o ciclo de vida e a idade dos informantes.

Marques (2007) encontrou relação significativa entre a idade e certos tipos de sociabilidade, bem como com o tamanho e o localismo das redes. Para os mais velhos, a pesquisa do autor evidenciou uma tendência de redução do tamanho, da diversidade das esferas de sociabilidade e maior localismo dos nós, de modo semelhante ao apontado por Blokland (2003) em sua análise de ciclo de vida. Desse modo, manteve-se a atenção

\footnotetext{
${ }^{54}$ Uma rede encontrada com esse perfil de fragmentação é a da entrevistada número 5, cujo sociograma está exposto no próximo capítulo.
} 
para possíveis influências desse tipo de dinâmica sobre as redes captadas, considerando a faixa etária dos entrevistados.

Nessa discussão sobre a variação da rede nos dois tempos e possíveis influências de fatores como idade e ciclo de vida, principalmente, é preciso ponderar que a rede no t1 foi construída como rede atual - ou no t2, se preferir. Isto significa que as pessoas citadas são aquelas que se mantiveram na rede ao longo do tempo com relevância tal a ponto de serem citadas atualmente. Desse modo, possíveis interferências em termos de idade e ciclo de vida podem ser minimizadas pelo próprio ego na construção da sua rede.

A partir desse procedimento adotado para elaboração de duas redes em períodos distintos é possível perguntar como fica a dinâmica dos demais atributos. Em relação às esferas de sociabilidade, estas foram captadas atualmente e imputadas para o primeiro período. Considerou-se que do mesmo modo que a rede está sendo construída a posteriori, a esfera citada hoje corresponderia a esfera do nó no primeiro período. Ainda que alterações possam ter ocorrido, essa consideração estabelece os mesmos parâmetros para todas as redes, possibilitando a análise comparativa dos dados.

Com relação ao pertencimento ou não ao bairro, também chamado de localismo dos nós, encontramos casos de pessoas que moravam no bairro e que se mudaram. Devido a importância dos laços criados pela moradia no bairro, principalmente entre aqueles que compartilharam os primeiros anos da Vila Castelo Branco, operação semelhante a adotada com os nós que morreram foi utilizada. Os indivíduos foram identificados como moradores do bairro no primeiro período e moradores de fora no segundo, sendo que a categoria mudou foi incorporada à rede de modo a assinalar essa informação.

Nesse item é importante não confundir o localismo de cada nó com a esfera de sociabilidade de vizinhança. Isto porque um nó que seja de dentro do local estudado pode ser inscrito em diversas esferas de sociabilidade, de acordo com a classificação que o ego fizer deste. Como exemplo, um nó de dentro pode ser citado como vizinho, mas também como família ou amigo. Essa sutileza mostra maior relevância se considerarmos a importância da especificação do lugar de moradia dos indivíduos da rede para o objetivo deste trabalho.

Em sentido complementar, a esfera de vizinhança também não necessariamente correspondeu aos limites do bairro, concordando com a classificação de Barnes (1954) de redes sem fronteiras. Segundo o autor, assim como amizade e parentesco, essas são esferas traçadas cognitivamente pelos indivíduos, independente das situações formais da 
relação estabelecida ${ }^{55}$. Sobre a vizinhança, por exemplo, ocorreram vários casos de pessoas identificadas como vizinhos, mas que não moram no bairro. Destes, além dos que moram em regiões próximas, há também indivíduos que já moraram no bairro, mas não moram mais.

Outra questão sobre as esferas é que grande parte dos nós das redes, principalmente aqueles pertencentes ao bairro, apresentam delimitações de esfera muito confusas para os próprios entrevistados. Parentesco, vizinhança, contato do bar e do futebol, da associação do bairro e do samba são por vezes, as mesmas pessoas. O parentesco é sintomático nesse sentido, pois muitos entrevistados consideram vizinhos, por exemplo, como familiares.

É evidente nesse caso como as pessoas fluem entre as esferas, pertencendo a mais de uma delas, constituindo o que Ferrand, Mounier e Degenne (1996) chamam de multiplexidade dos vínculos, ou seja, dois diferentes tipos de laços entre os dois mesmos atores.

\footnotetext{
${ }^{55} \mathrm{O}$ estudo empreendido trouxe um exemplo no caso da família: uma sogra que continua considerando a ex-nora como parte da família, inclusive a identificando como nora, mesmo essa já tendo sido substituída oficialmente.
} 


\section{CAP. 3 - CONSIDERAÇÃO DE DOIS PERÍODOS: RETRATOS DA MUDANÇA RECONSTRUÍDA HOJE}

\subsection{Retratos da mudança}

Como já foi dito ao longo da dissertação, foram realizadas trinta entrevistas com moradores do bairro selecionados de acordo com o tempo de moradia nesse. Interessaram principalmente aqueles que moram na Vila Castelo Branco desde pelo menos a década de 1980 e que tenham vivido as mudanças espaciais ao longo dos anos, sendo que a grande maioria dos entrevistados selecionados mora desde a época de construção das casas.

Resultante das entrevistas, as redes analisadas nesse capítulo são redes pessoais, elaboradas a partir de entrevista egocentrada, isto é, a construção da rede total do indivíduo a partir de perguntas à ele - ego - sobre suas relações. Nelas, identifiquei o período de entrada de cada nó na rede de modo a compor duas redes, uma em cada período, para observar como elas se comportam no caso do espaço segregado e do mesmo espaço incorporado à cidade.

Um primeiro efeito esperado da relação entre espaço e redes seria a ampliação das últimas com a integração do bairro, devido a considerações correntes na literatura sobre as restrições estabelecidas pela segregação inclusive sobre a inscrição dos indivíduos em círculos sociais mais amplos - como exploramos anteriormente.

No entanto, de maneira oposta a essa influência esperada do espaço, a faixa etária dos entrevistados poderia produzir um efeito inverso de redução das redes, devido a um processo geral de mudança das redes de acordo com o ciclo de vida dos indivíduos. De acordo com esse processo, há uma forte tendência de diminuição das redes conforme as pessoas envelhecem pela combinação de elementos como a saída do mundo do trabalho, a redução da mobilidade física e de atividades gerais que podem restringir as esferas de sociabilidade à família, vizinhança e amigos (Blokland, 2003; Marques, 2007).

Contudo, o resultado encontrado foi de aumento geral das redes, inclusive com o surgimento de novas esferas de sociabilidade no segundo período e, em muitos casos, esferas relacionadas justamente com a terceira idade, como grupos de atividades físicas, 
de viagens, de trabalhos manuais e voltadas à saúde médica ${ }^{56}$. Mesmo esferas relacionadas a trabalho, amizade e associativas foram criadas no segundo período, indicando uma população idosa com intensas atividades relacionais.

Apesar dessas observações, o aumento das redes e da quantidade de esferas no segundo período em relação ao primeiro pode ser encarado como resultado do próprio método em si, para além da influência da segregação ou do ciclo de vida. Isso porque a rede do primeiro período, ou t1, é construída atualmente, a partir da identificação da entrada do nó na rede antes ou depois do marco de separação dos períodos. Esse procedimento permite mantermos apenas os que entraram antes, criando uma rede correspondente a existente no t1. De fato, com exceção de duas redes que se mantiveram exatamente iguais nos dois períodos, todas as redes aumentaram do primeiro período para o segundo.

Dessa forma, mostrou-se relevante uma análise mais apurada dos tipos de mudanças que podem ser observadas entre os dois períodos, para além da simples constatação do aumento do tamanho geral das redes. Seguem os resultados obtidos e as interpretações realizadas.

\subsection{Redes em cada período e sua dinâmica}

O primeiro período considerado corresponde ao momento no qual a Vila Castelo Branco se encontra segregada da cidade de Campinas, nos moldes como foi apresentado no primeiro capítulo. Reforçando o que já foi dito anteriormente, esse período abarca desde o momento de sua inauguração em 1967 até meados da década de 1980. Desse modo, podemos considerar que essas primeiras redes são de indivíduos segregados e, com essa consideração em mente, procuraremos entendê-las e observar os efeitos dessa condição espacial.

O segundo período, também chamado de t2, é o momento no qual a Vila Castelo Branco passa a se integrar à cidade de Campinas. Como vimos anteriormente, a partir de

\footnotetext{
${ }^{56}$ A Vila Castelo Branco apresenta uma vasta gama de serviços e atividades voltadas à terceira idade, em grande parte devido ao fato de ser campo de estágio e atuação dos alunos dos cursos oferecidos principalmente na área de saúde pela Pontifícia Universidade Católica - PUC, cujo campus universitário próximo ao bairro favorece essa relação. Além dessa universidade, há o Projeto Gente Nova - Progen, ONG local que desenvolve atividades recreativas e educacionais para crianças e também para a terceira idade, bem como grupos que organizam viagens e atividades físicas e manuais existentes na própria vizinhança.
} 
meados da década de 1980 ocorrem mudanças espaciais na cidade de forma geral, incluindo a região onde se encontra o bairro. A comparação entre os períodos permite observar qual é o efeito dessas mudanças sobre as redes dos indivíduos que estavam segregados.

\subsubsection{Tamanho}

\section{Tamanho no t1}

A primeira análise que pode-se fazer diz respeito ao tamanho. O tamanho de uma rede é importante por que quanto maior a rede, mais possibilidades relacionais estão disponíveis para serem acessadas pelos indivíduos.

No caso dos entrevistados a média de número de nós da rede foi de 24,7 nós. Numa variação que vai de 5 a 67 nós, dezoito casos se concentram na faixa entre 10 e 30 nós, revelando que a média se aproxima satisfatoriamente do que foi encontrado.

Além do número de nós, há outras dimensões da rede que também informam sobre seu tamanho, de acordo com outros aspectos relevantes nesse quesito. O número de vínculos que cada nó possui dentro da rede, o diâmetro desta e a densidade dos vínculos, dão parâmetros de como esses nós se relacionam entre si, bem como complementam a idéia de tamanho de cada rede.

A média do número de vínculos das redes no primeiro período foi de 63,27 , variando de redes com 12 a 238 vínculos. É importante notar que a relação entre o número de nós e o número de vínculos não é direta, podendo haver redes com o mesmo número de nós, mas com diferente quantidade de vínculos como no caso da entrevistada número 20 e entrevistada número 5. Ambas têm 24 nós em suas redes cada uma, mas apresentam 48 e 64 vínculos respectivamente, como vemos nos sociogramas abaixo. 
Figura 1 - Sociograma da entrevistada 20 no t1

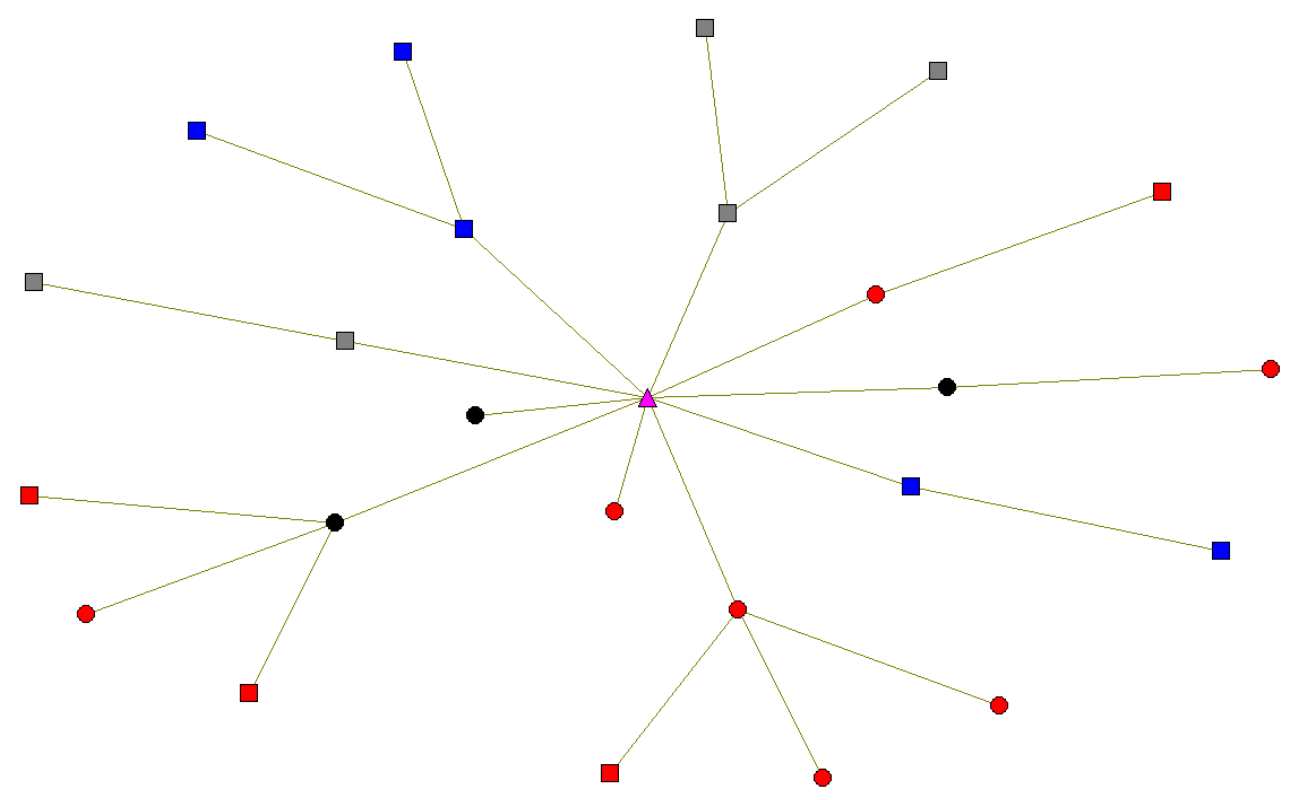

Legenda:

Triângulo rosa - ego

Localismo

Círculos - dentro

Quadrados - fora
Esfera

Azul - Família

Vermelho - Vizinhança

Preto - Associação

Cinza - Trabalho 


\section{Figura 2 - Sociograma da entrevistada 5 no $t 1^{57}$}
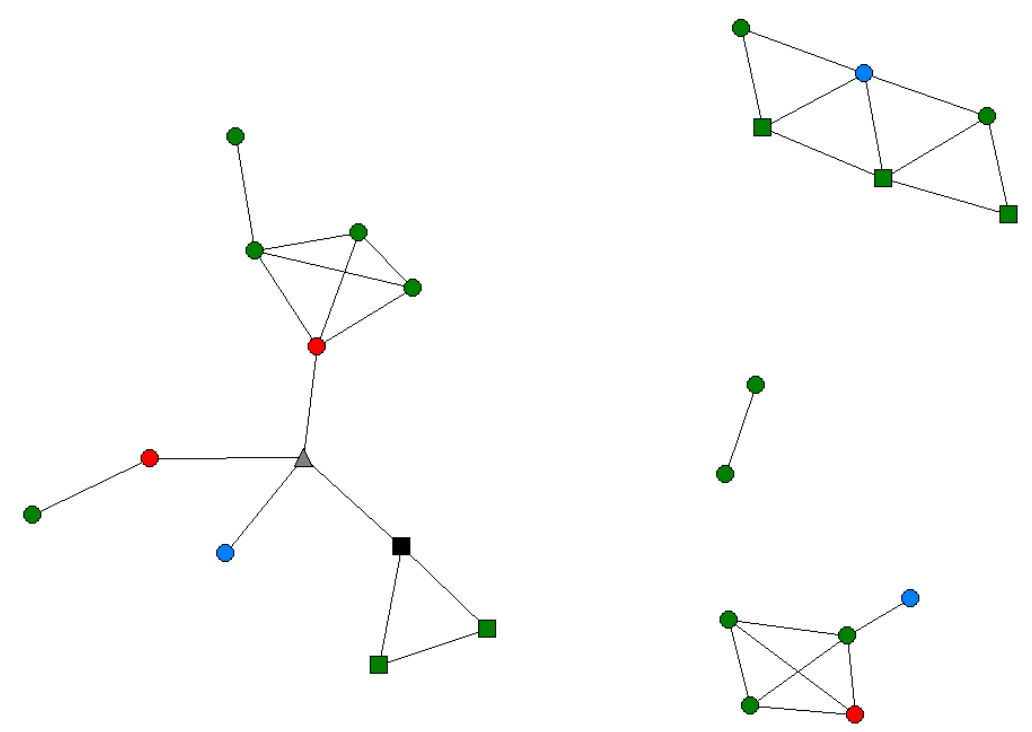

\section{Legenda: \\ Triângulo cinza - ego}

Localismo

Círculos - dentro

Quadrados - fora

\section{Esfera}

Azul - Família

Vermelho - Vizinhança

Preto - Igreja

Verde - Não classificados

Nesses exemplos acima vemos duas composições de redes bem distintas. Apesar da segunda (entrevistada 5) apresentar nós desprendidos da rede, o número de vínculos entre os nós é bastante superior ao da entrevistada 20, cuja rede não apresenta grande conexão entre os nós. Ambas as redes apresentadas acima são exemplos da média do número de nós, sendo que a entrevistada 5 é a que mais se aproxima da média do número de vínculos encontrados nas redes. Esta rede também ilustra o exemplo da média de diâmetro, isto é, cinco passos de distância.

A medida de diâmetro indica qual é a maior dentre as menores distâncias entre dois nós quaisquer de uma rede, sendo uma medida indireta de tamanho dada pela conectividade geral da rede. O diâmetro vai além das ligações diretas entre os nós da

\footnotetext{
${ }^{57}$ A explicação metodológica da obtenção de redes fragmentadas se encontra no capítulo 2.
} 
rede e abarca as relações que cada nó pode oferecer ao outro, captando a complexidade das ligações. "That is, sometimes being a "friend of a friend" may be quite consequential" (Hanneman e Riddle, 2005), ou seja, alguns nós podem oferecer mais oportunidades relacionais que outros, devido ao maior leque de vínculos que dispõe. Além disso, dependendo do diâmetro da rede as informações e recursos podem fluir mais ou menos rapidamente entre os indivíduos dela pertencentes. Ou seja, quanto maior o caminho, mais custoso e menos eficiente ele é, pensando em custos e eficiência tanto em termos econômicos quanto em termos afetivo e de tempo. Nesse primeiro período, o diâmetro variou de três a nove passos na rede, apresentando uma média de 5,2 passos ou nós.

Ainda sobre o tamanho, a densidade da rede é obtida pelo cálculo da proporção entre os vínculos existentes e os teoricamente possíveis de serem construídos em uma dada rede, ou seja, avaliando a densidade encontrada em relação a uma densidade plena, com todos os nós estabelecendo conexões entre $\mathrm{si}^{58}$. Nesse caso a média encontrada foi de 0,1386 , indicando que $13,86 \%$ dos possíveis laços foram efetivados, aparentando uma baixa densidade.

\section{Tamanho no t2}

No segundo período, a média de número de nós foi de 50,8 nós por rede. De fato, a maior parte das redes se encontra numa faixa entre 10 a 40 nós (dezoito casos); sendo que desses, nove casos se concentram entre 20 e 30 nós. No entanto, a variação do número de nós de 9 à 263 foi bem grande, com apenas um caso de rede com menos de dez nós e também um caso com mais de duzentos nós, diferenciando da distribuição de tamanho encontrada no primeiro período cuja variação estava mais concentrada.

Da mesma forma como já vimos para o primeiro período, a análise do número de vínculos contribuiu para a compreensão do tamanho e do comportamento deste. Nesse caso, a média foi de 150,40 vínculos por rede, variando de 20 (entrevistado número 29 com nove nós) a 562 vínculos (entrevistado número 25 com duzentos e sessenta e três nós).

\footnotetext{
${ }^{58} \mathrm{O}$ cálculo realizado toma a soma dos vínculos e divide pelo número de todos os possíveis vínculos. (Hanneman e Riddle, 2005).
} 
Com relação ao diâmetro, a média encontrada foi de 5,8 passos, variando de dois a nove passos.

Por fim, a densidade média nesse período foi de $9,4 \%$ dos laços possíveis. É importante entender que a densidade tem uma relação inversamente proporcional ao tamanho, ou seja, quanto maior a rede há uma tendência dela ser menos densa. Isto porque quanto maior a rede aumenta as chances dos nós não estabelecerem vínculos entre si. Os resultados encontrados para o segundo período confirmam essa tendência, uma vez que as redes foram maiores e menos densas nesse momento.

\section{Tamanho nos dois tempos}

A comparação entre os períodos subentende a análise das mudanças das redes entre os dois tempos abordados, o que difere substancialmente da análise dos elementos que as compõe de forma fixa. Isto é, a comparação em termos de tamanho, por exemplo, estaria revelando não o tamanho da rede como grande ou pequeno em relação a outras redes dentre os entrevistados e mesmo em relação a outros casos. O procedimento adotado revela o aumento, diminuição ou manutenção do tamanho, ou seja, é uma análise dinâmica de cada rede pessoal em dois momentos de observação que se referem à mudança espacial. O mesmo pode ser dito para os outros aspectos analisados a seguir, como homofilia de sexo, localismo dos nós e diversidade da sociabilidade.

Como visto na descrição de cada período, as redes encontradas entre os moradores da Vila Castelo Branco variaram muito no que diz respeito ao seu tamanho de acordo com o número de nós, tanto no t1 quanto no t2. Retomando os resultados encontrados, no primeiro período as redes apresentaram média de 24,7 nós por rede, enquanto no segundo tempo a média foi de 50,8 nós, deixando perceptível o aumento.

Analisando o número de nós, foi possível identificar o aumento sofrido pelas redes, a partir da comparação entre os períodos. A maioria das redes teve um aumento que variou de 20 a 50\% de novos nós (dezoito casos), com grande parte das redes na faixa dos 40 a $50 \%$ de novos nós (oito casos). Dessa forma pode-se ressaltar crescimento da maior parte das redes com média de $40 \%$ novos nós de um período para o outro.

Complementando essa informação, é interessante assinalar que foi encontrada rede com até $87 \%$ de novos nós; rede esta que continha cinco nós no t1 e trinta e nove 
no $\mathrm{t}^{59}$. Ao mesmo tempo, dois casos mantiveram exatamente a mesma rede ao longo do tempo, uma delas com vinte e dois nós e a outra com trinta nós nos dois períodos ${ }^{60}$. O menor aumento constatado foi de $11 \%$ em duas redes relativamente pequenas; uma com oito nós no $t 1$ e nove nós no $\mathrm{t} 2$ e outra rede passou de dezesseis para dezoito nós ${ }^{61}$.

Entre as redes que não sofreram mudanças entre os tempos temos o caso da entrevistada número 27 que apresenta uma rede com trinta nós e sessenta e quatro vínculos que nela estão desde o primeiro período. Sua densidade é de 6,8\% e apresenta diâmetro de seis passos.

Como vemos no sociograma a seguir, há predominância da esfera vizinhança com vinte e cinco nós (mais de $83 \%$ da rede) e de pessoas de dentro do bairro (vinte nós ou $66,7 \%$ da rede). A entrevistada em questão é uma mulher de 51 anos, aposentada por invalidez desde 1985, com renda familiar mensal de mais de 3 salários mínimos e é natural de Campinas. Outra informação que não aparece no gráfico é que sua rede é bastante homofílica em termos sexuais, concentrando $73 \%$ de mulheres, ou seja, vinte e dois nós e que o marco temporal utilizado foi sua aposentadoria.

As redes selecionadas para ilustrar as análises que se seguem são aquelas que apresentaram dados mais próximos das medidas consideradas e/ou das médias encontradas para o conjunto dos entrevistados.

\footnotetext{
${ }^{59}$ A rede com maior aumento do número de nós entre os períodos foi a da entrevistada 21 , que veremos a seguir nas figuras 4 e 5 .

${ }^{60}$ As redes que se mantiveram sem alterações foram as da entrevistada número 23 e entrevistada 27. O sociograma desta última entrevistada compõe a figura 3 na próxima página.

${ }^{61}$ As duas redes com menor aumento encontrado foram do entrevistado número 29 e entrevistada 11 . O sociograma da entrevistada 11 no t2 aparece na figura 8 na página 91.
} 
Figura 3 - Sociograma da entrevista 27 no t1 e no t2 - rede sem alteração

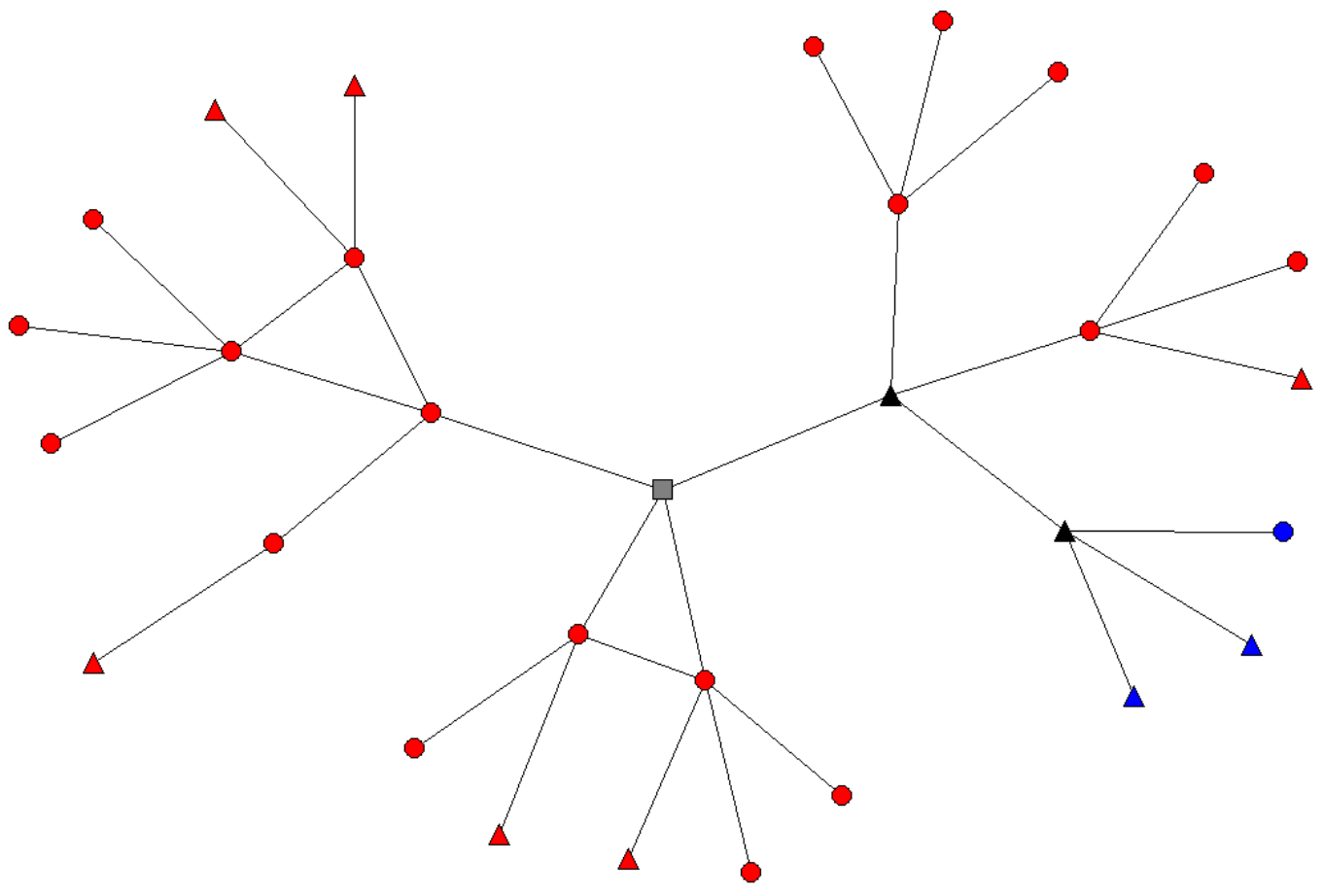

Legenda:

Quadrado Cinza - Ego

Localismo

Esfera

Círculos - dentro

Preto - Família

Triângulos - fora

Vermelho - Vizinhança

Azul - Amizade

Entre as redes que sofreram grande crescimento geral, destaco o caso da entrevistada número 21 que teve o maior percentual de crescimento, com $87 \%$ de novos nós no t2. Ela é uma mulher com oitenta anos de idade, aposentada há dezoito anos, mas continua trabalhando como comerciante em sua residência. Nasceu em São Sebastião do Paraíso-MG e mora em Campinas há 56 anos. 
Figura 4 - Sociograma da entrevistada 21 no t1 - rede com grande aumento

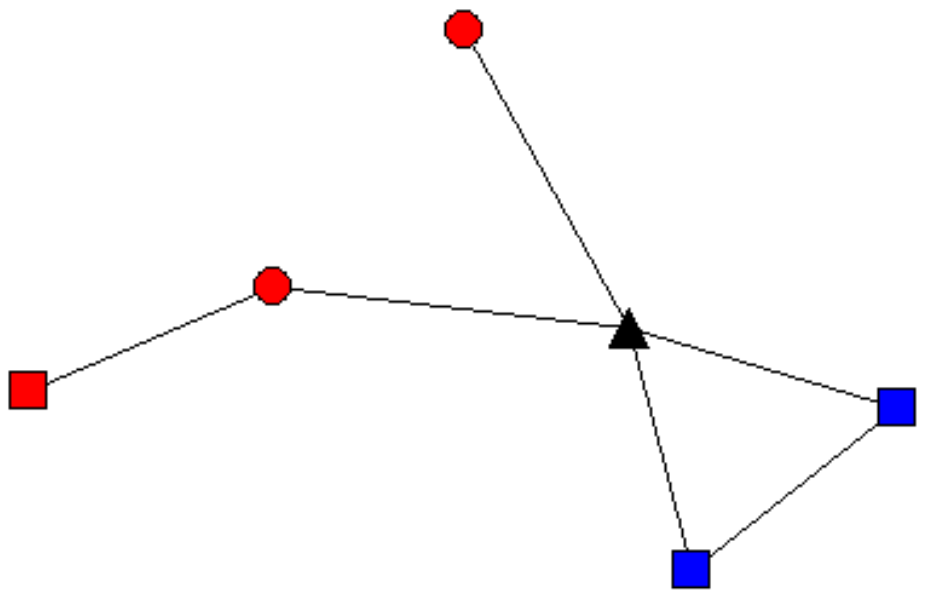

Legenda:

Triângulo preto - ego

Localismo Esfera

Círculos - dentro Azul - Família

Quadrado - fora

Vermelho - Vizinhança

Figura 5 - Sociograma da entrevistada 21 no t2 - rede com grande aumento

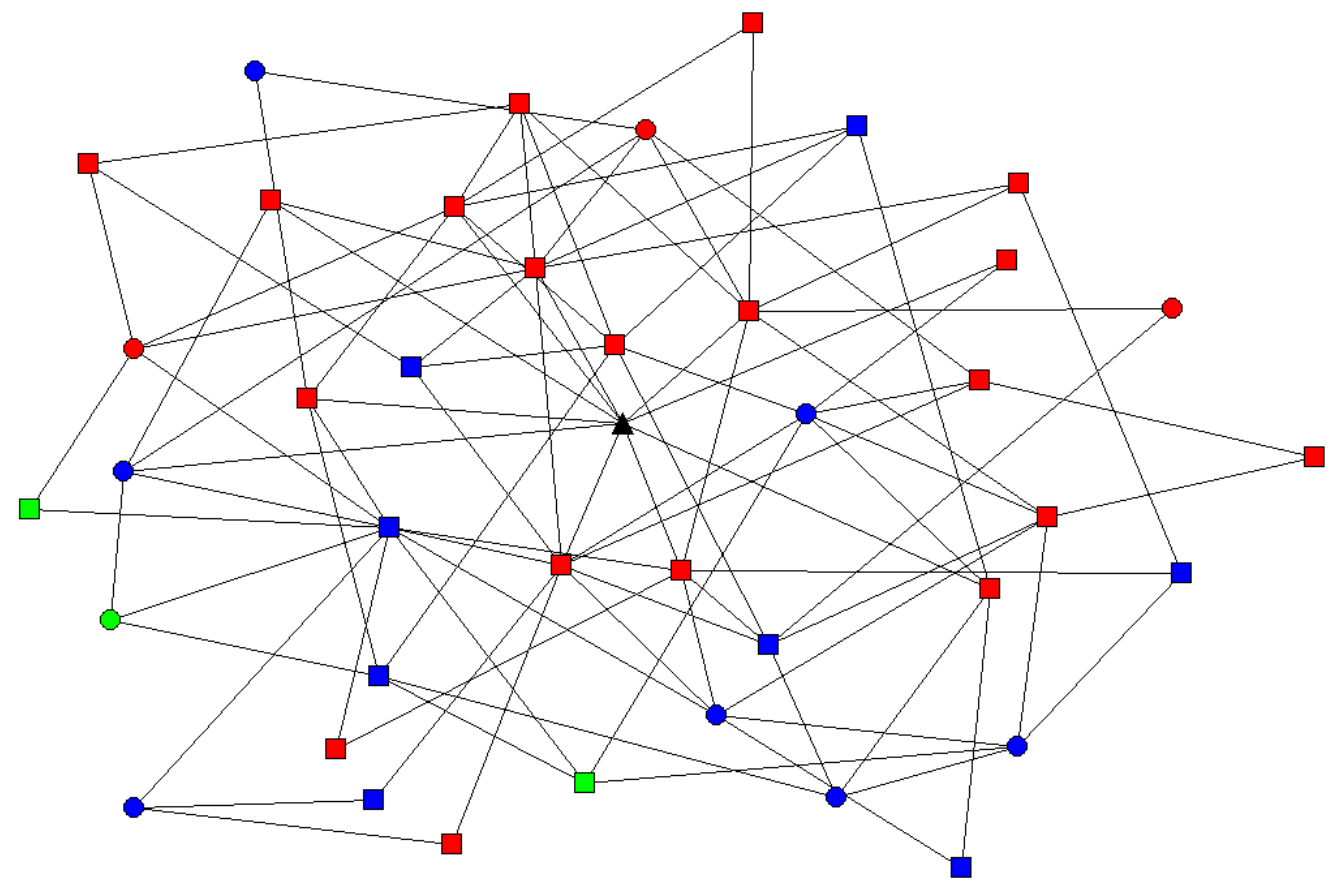




\section{Legenda:}

Triângulo preto - ego

\begin{tabular}{ll} 
Localismo & Esfera \\
\hline Círculos - dentro & Azul - Família \\
Quadrado - fora & Vermelho - Vizinhança \\
& Verde - Religião
\end{tabular}

Como podemos ver nos sociogramas a rede da entrevistada número 21 tinha cinco nós no primeiro período e passa a ter 39 no segundo. Seu número de vínculos também cresce enormemente, passando de doze a cento e noventa e dois. Seu diâmetro cresce de três para quatro passos e a densidade cai de $40 \%$ para $11 \%$ dos nós possíveis. Com relação a homofilia de sexo, sua rede é bastante homofílica no primeiro período, sendo $80 \%$ dos nós de mulheres, e no segundo a quantidade de nós do sexo oposto supera a do mesmo sexo, passando a ter $46 \%$ de homofilia, indicando outra importante alteração .

Entre as esferas, a que mais cresceu foi a da família - de dois para vinte e um nós - e a criação da esfera religião acrescentou mais três novos nós em t2. Em relação ao localismo dos nós, a maioria é de fora nos dois tempos. Podemos assinalar também que essa rede é bem emaranhada no segundo período, com os nós se relacionando bastante entre si e entre as esferas.

Por fim, apresento uma rede para ilustrar a média de aumento que variou de 30 a $40 \%$ de novos nós inseridos no t2. Trata-se da entrevistada número 19, cuja rede passou de dezessete a trinta nós, crescendo $43 \%$. Seus vínculos cresceram de 72 para 134, seu diâmetro de cinco para seis passos e sua densidade diminuiu de $23,5 \%$ para $14,4 \%$ dos possíveis laços entre os nós. Sobre a composição sexual, sua rede aumentou a homofilia no segundo período para $67 \%$, sendo que era até relativamente equilibrada a distribuição entre homens e mulheres no primeiro tempo, com 53\% de mulheres. 
Figura 6 - Sociograma da entrevistada 19 no $t 1$ - média de aumento

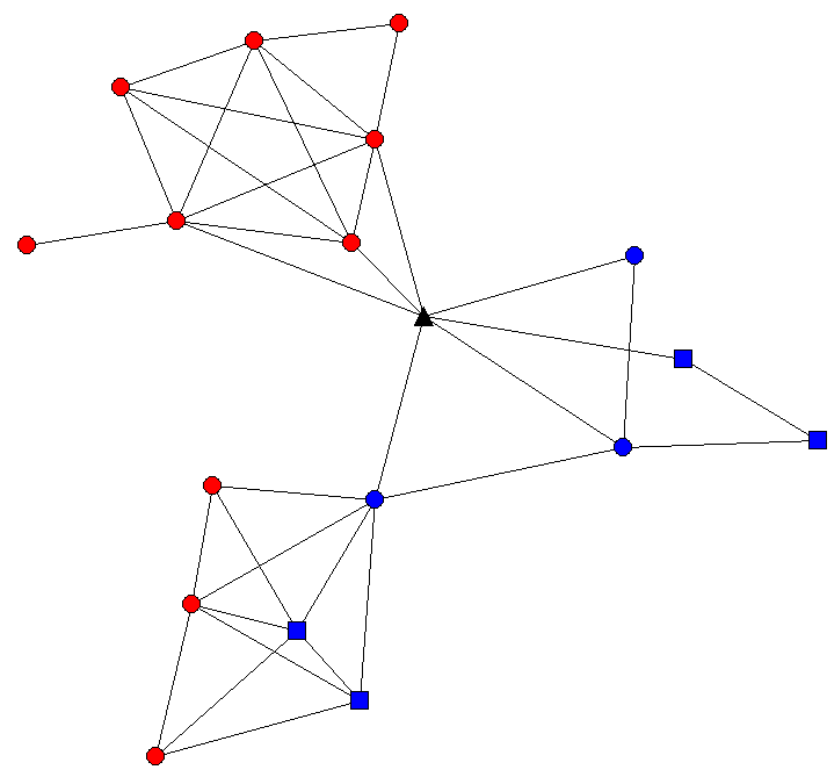

Legenda:

Triângulo preto - ego

Localismo

Círculos - dentro

Quadrados - fora
Esfera

Azul - Família

Vermelho - Vizinhança

Figura 7 - Sociograma da entrevistada 19 no $\mathbf{t} 2$ - média de aumento

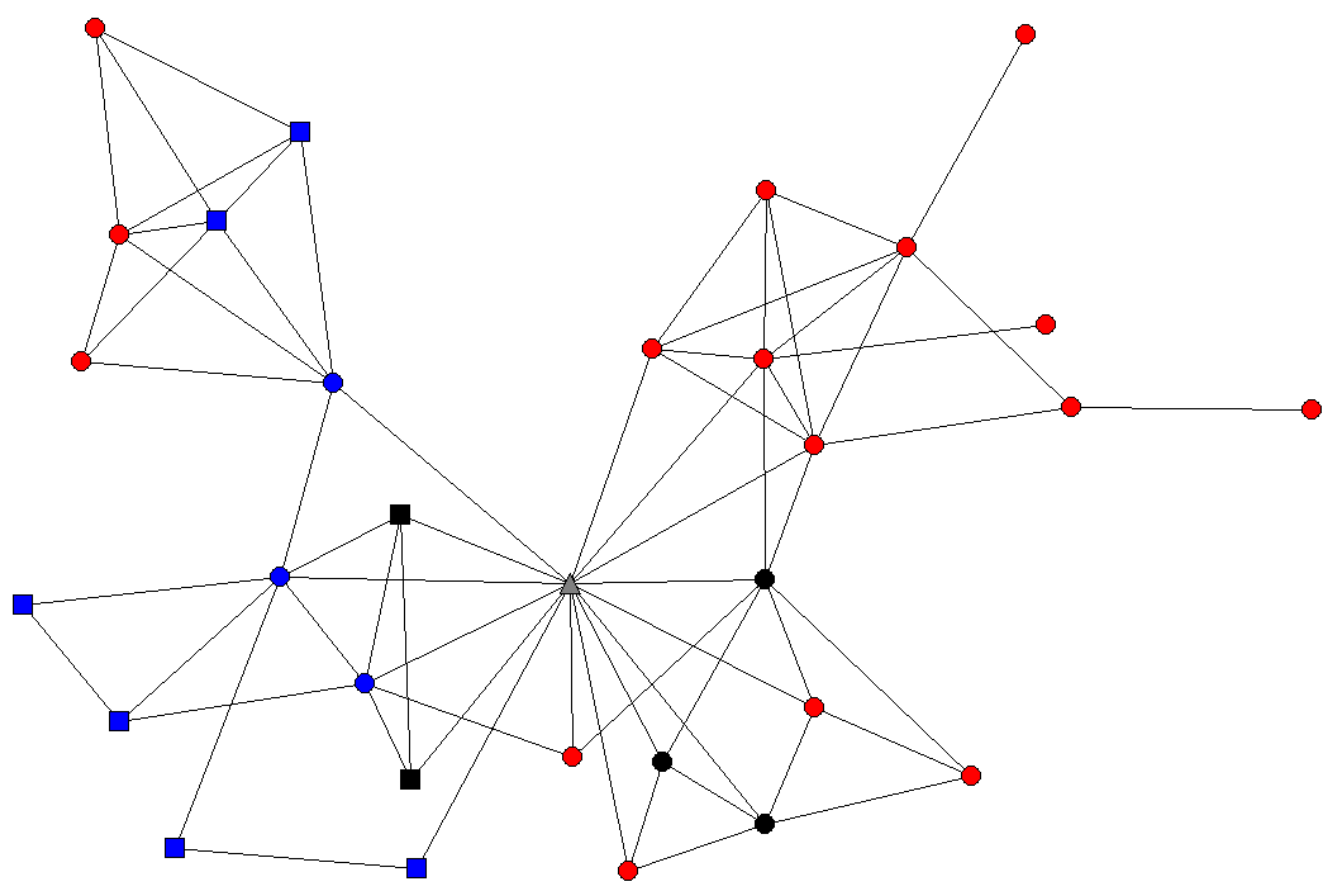




\section{Legenda:}

Círculo cinza - ego

\begin{tabular}{ll} 
Localismo & Esfera \\
\hline Círculos - dentro & Azul - Família \\
Quadrados - fora & Vermelho - Vizinhança \\
& Preto - Igreja
\end{tabular}

Essa mulher tem 62 anos, é aposentada, com renda familiar mensal maior que três salários mínimos por mês, natural de Casa Branca. Os dados revelam que sua rede cresceu mais dentro no t2 e a esfera com maior predominância é a vizinhança nos dois tempos. No segundo período passa a existir a esfera igreja que contribui com cinco novos nós. Sua rede também é bem articulada, havendo vários vínculos entre as esferas e entre os nós, ainda que de modo mais ameno do que no caso anterior.

Comparando essas redes com os dados de seus perfis, constata-se que aquelas que não mudaram entre os tempos são de pessoas mais novas dentre os entrevistados. Enquanto que tanto as de menor aumento, quanto de maior aumento dizem respeito a pessoas relativamente mais velhas, sendo o maior aumento encontrado justamente na rede da pessoa mais idosa do universo da pesquisa.

A literatura sugere uma tendência de redes maiores para os mais jovens e menores para os mais velhos, devido a dinâmicas relativas ao ciclo de vida; como saída do mercado de trabalho, redução da mobilidade em geral e até mesmo morte de pessoas que compunham a rede em outros momentos (Blokland, 2003). Entretanto, como já dito antes, a grande maioria das redes sofreu aumento de um tempo para o outro, contrariando essa tendência já que no segundo período os entrevistados estariam mais velhos que no primeiro.

No entanto, a amostra de moradores da Vila Castelo Branco é composta por idosos, de forma que os mais novos entre os idosos seriam afetados pela mesma tendência apontada pela literatura que os mais velhos dentre estes entrevistados. Apesar disso, o resultado encontrado não confirma essa tendência, evidenciando que pode haver maior complexidade no tipo de rede das pessoas dessa fase do ciclo de vida do que a delineada pela bibliografia quando se considera a dinâmica da mesma rede captada em dois períodos distintos. 
Outra regularidade observada diz respeito a relação entre tamanho da rede e escolaridade. Constatou-se que as redes que tiveram o menor aumento são de pessoas com maior tempo de estudo. Em termos mais concretos, as duas redes que tiveram apenas $11 \%$ de novos nós são de pessoas com oito anos de estudo. Por outro lado, a rede com o maior aumento do número de nós no segundo período pertence a uma entrevistada que nunca estudou.

Marques (no prelo) encontrou forte relação positiva entre maior escolaridade e tamanho da rede entre os pobres pesquisados em São Paulo. Isto é, quanto mais tempo de estudo, maior seria a rede, bem como maior seria a variabilidade da sociabilidade. No entanto, o resultado encontrado para a Vila Castelo Branco refere-se a dinâmica da rede e, nessa questão, esse resultado se opõe ao esperado pela bibliografia.

Em contrapartida, deve-se levar em conta que a vida escolar dos entrevistados sofre a influência da baixa escolaridade e também da faixa etária destes. Um aspecto representativo dessa condição é a própria inexistência da esfera de sociabilidade de estudos entre os exemplos destacados acima.

As redes também apresentaram um aumento do número de vínculos de uma forma geral. É claro que aquelas que não se alteraram ao longo do tempo não apresentarão mudanças em nenhum dos aspectos analisados, da mesma forma que as redes que tiveram poucos nós acrescentados apresentam alterações menores. No entanto, de forma geral encontramos uma média de $45 \%$ novos vínculos gerados do primeiro para o segundo período. Aqui, vale ressaltar que a variação foi de 0 até $94 \%$ de novos vínculos, destacando as redes da entrevistada 21, apresentada acima, com 94\% novos vínculos, tendo em segundo lugar o entrevistado número 25 com $81 \%$ de crescimento nesse quesito.

Com relação ao diâmetro, apesar de uma pequena variação entre as médias da distância média das redes de 2,84 no t1 para 3,23 no t2, o número de passos se manteve quase o mesmo, variando apenas a casa decimal. Nesse ponto é interessante notar que há uma rede que diminuiu um passo, de 3 para 2 - entrevistada 28 -, podendo ter aumentado a relevância dos contatos por ter tornado o caminho entre os nós mais curto e, conseqüentemente, menos custoso. Essa mudança em seu diâmetro foi acompanhada pelo aumento de sua densidade, isto é, aumentaram-se as possibilidades de construção de vínculos. 
Contudo, esse foi um caso à parte, pois como a grande maioria das redes aumentaram na passagem do tempo as densidades diminuíram de $13,86 \%$ para $9,4 \%$ dos vínculos possíveis, de acordo com a relação inversa entre esse aspecto e o tamanho.

No entanto, como vimos anteriormente o aumento do tamanho da rede de um período para o outro em si é um dado que deve ser tomado com cautela e em conjunto com a análise de outros elementos. Enquanto a dimensão de tamanho é captada através da variável do número de nós, sua constatação isolada, ou seja, a definição de grande ou pequena através da quantidade de nós que ela possui, não define a potencialidade dessa rede, uma vez que os contatos podem se organizar de diversas maneiras entre si ou serem redundantes. Devido a essa observação, além das dimensões inerentes ao tamanho como as expostas acima, outros aspectos das redes podem informar melhor sobre seu comportamento e possibilidades relacionais. A seguir veremos alguns desses aspectos.

\subsubsection{Homofilia de sexo}

\section{Homofilia de sexo no t1}

A homofilia em geral diz respeito ao compartilhamento de mesma característica entre o ego e as pessoas que compõem sua rede, de forma que pode referir-se a qualquer característica escolhida. Neste caso, destacamos a homofilia em relação ao sexo.

Feita essa consideração, com relação a esse aspecto as redes tiveram uma média de $68 \%$ dos nós de pessoas do mesmo sexo que o ego no primeiro período, indicando alta homofilia.

Separando a análise por sexo, vemos que as mulheres tiveram redes mais homofílicas que os homens, apresentando média de $71 \%$ de seus nós compostos por mulheres. De fato, a grande maioria das redes com egos femininos ( $74 \%$ dos casos) apresentaram redes com mais de $60 \%$ de seus nós do mesmo sexo, ocorrendo inclusive uma rede formada unicamente por mulheres. Os homens, por sua vez, tiveram $59 \%$ de homofilia, não diferindo muito do resultado entre as mulheres. 


\section{Homofilia de sexo no t2}

Na questão da homofilia de sexo as redes tiveram uma média de 67\% de pessoas com o mesmo sexo do nó por rede. De acordo com cada sexo, as mulheres apresentaram média de $69 \%$, enquanto os homens tiveram um pequeno aumento na média de homofilia, passando a $61 \%$.

A seguir, é apresentada a rede da entrevistada 11 que foi totalmente formada por mulheres nos dois períodos, com 100\% de homofilia de sexo. De fato sua rede mudou muito pouco do $\mathrm{t} 1$ para o $\mathrm{t} 2$, com o acréscimo de dois nós apenas, na esfera da família no sociograma abaixo seriam os dois braços que se abrem da linha à direita.

Figura 8 - Sociograma da entrevista 11 no t2

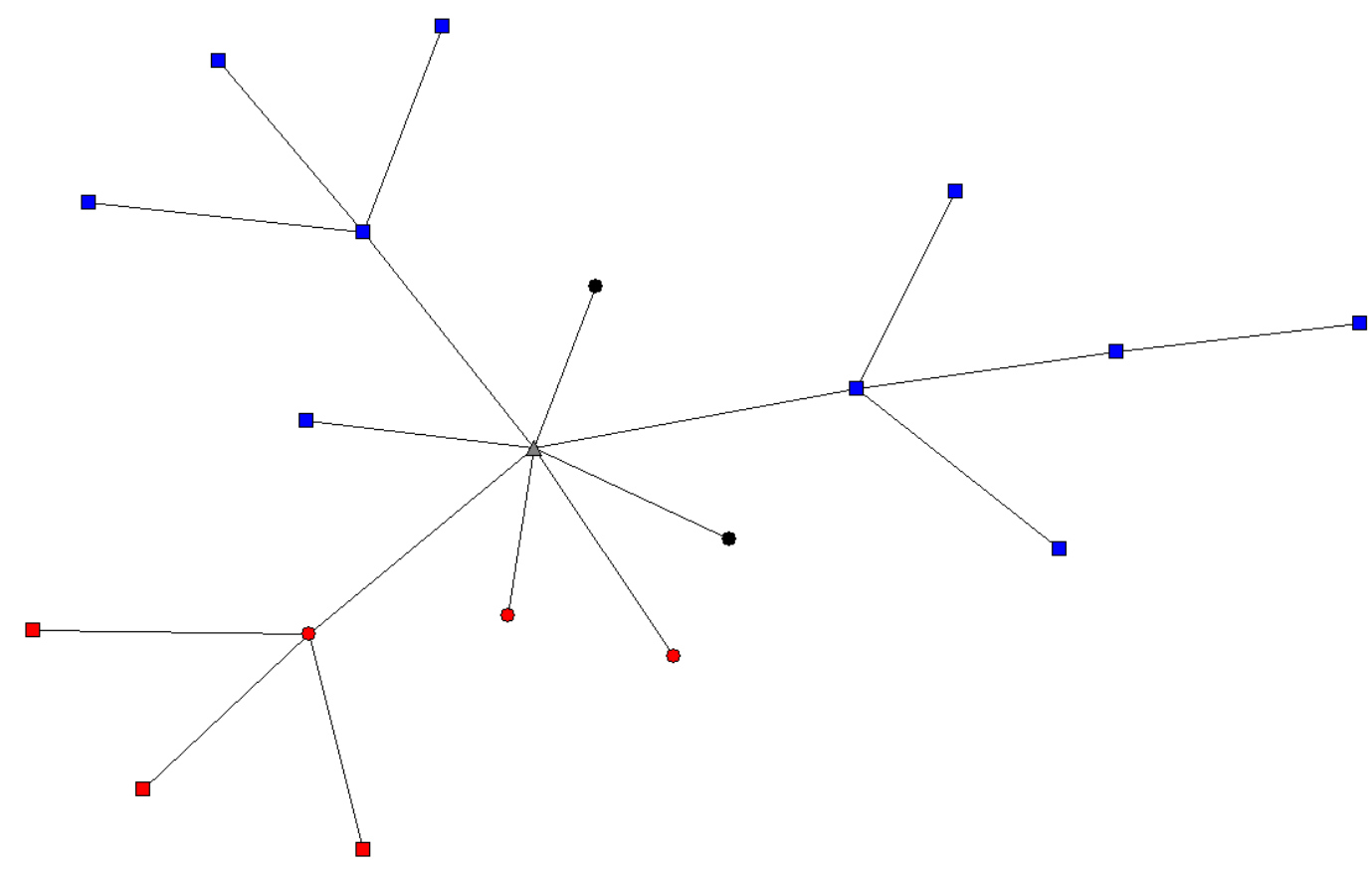

Legenda:

Triângulo cinza - ego

Localismo Esfera

Círculos - dentro

Azul - Família

Quadrados - fora

Vermelho - Vizinhança

Preto - Igreja 


\section{Homofilia - nos dois tempos}

A média de homofilia entre as redes pesquisadas variou muito pouco entre os tempos. A homofilia de sexo no t1 foi de $68 \%$ e $67 \%$ no t2. Fazendo uma análise de comparação entre os tempos de forma um pouco mais detalhada temos que dezoito redes apresentaram pouca variação homofílica entre os dois períodos considerados. Das demais, seis apresentaram aumento e outras seis diminuição da distribuição de sexo na rede de acordo com o sexo do ego. De toda forma, ainda numa análise geral sobre as redes, nenhuma delas apresentou composição com menos de $40 \%$ dos nós do mesmo sexo que o ego.

Separando a análise de acordo com o sexo do ego, foi observado que entre as redes de mulheres a homofilia foi maior que entre as redes dos homens. Sendo que as primeiras apresentaram uma média de $71 \%$ no t1 e $69 \%$ no t2, enquanto os homens $59 \%$ e $61 \%$ respectivamente em cada período.

Entre as mulheres, a maioria das entrevistadas apresentou redes com mais de $60 \%$ composta por nós femininos, tanto no t1 (dezessete dentre as vinte e três mulheres entrevistadas) quanto no t2 (dezesseis entrevistadas). Há inclusive o caso da entrevistada número 11 com rede exclusivamente composta por mulheres nos dois períodos, como exposto acima.

Já os homens apresentaram um pouco mais de equilíbrio entre o sexo dos nós em suas redes, pois grande parte dessas apresentou de 40 a $60 \%$ de homofilia. No entanto, não podemos tomar esses dados como definitivos devido o tamanho da amostra de homens na pesquisa.

Outro dado que reforça a presença de homofilia de sexo nas redes é que apenas quatro redes dentre as sessenta dos dois tempos apresentaram maior predominância de pessoas de sexo diferente do sexo do ego. Duas dessas redes no primeiro período e outras duas no segundo. A conclusão que se chega é que apesar de haver algumas diferenças principalmente se dividirmos as redes entre homens e mulheres, a homofilia de sexo é alta e não muda de um período para o outro de modo contundente.

Dado esse resultado, é possível assinalar que o princípio de ação homofílica de Granovetter (1973) tem menor relevância em termos sexuais nesse caso do que se pensarmos em homofilia de local ou de esferas de sociabilidade. Isso porque no âmbito dessa investigação não foi possível aprofundar que tipo de conseqüência a predominância de homens ou mulheres pode trazer para as redes. De modo geral, esse 
aspecto não introduziu nenhum impacto entre os períodos, mesmo dividindo as redes entre os sexos.

Como tanto as redes de homens quanto de mulheres tenderam a apresentar maior predominância de pessoas do mesmo sexo do ego é possível que essa distribuição seja mais resultado de outro tipo de interação que a desencadeada pela mudança espacial. De fato, procurou-se testar se haveria maior diversidade de composição sexual das redes dada a mudança espacial observada, o que não se confirmou. No entanto, as evidências levantadas não devem ser tomadas como conclusivas.

Por outro lado, a homofilia sexual não é um elemento que apresenta relação direta com o espaço e sua pouca alteração entre os períodos pode inclusive ressaltar as mudanças observadas nos demais aspectos analisados que podem ter essa relação estabelecida mais diretamente. De forma que, comparativamente com os outros resultados, reafirma o que mudou como relevante e indicativo da relação explorada entre espaço e redes sociais.

\subsubsection{Localismo}

\section{Localismo no t1}

Outra característica de homofilia entre os nós pode ser seu local de moradia, o que se denomina como localismo dos nós. O localismo aqui é tomado a partir da dicotomia entre as pessoas que moram dentro da Vila Castelo Branco e fora do bairro, entendendo que as redes mais locais são aquelas que contêm mais nós de dentro. Essa é a dimensão que mais diretamente correlaciona as redes e o espaço.

Nesse primeiro período percebe-se que a média de nós de dentro é superior a média dos nós de fora da Vila Castelo Branco, sendo 56\% dentro e 44\% fora. Desta forma, na análise do localismo dos nós, isto é, se o nó é de dentro ou de fora do bairro em questão, constata-se uma maior concentração de pessoas do próprio bairro nas redes analisadas.

Para melhor apuração do dado é possível distribuir as redes em faixas de porcentagens de nós de dentro e de fora para comparação com a média encontrada. Nesse tipo de exercício, encontrou-se que no $\mathrm{t} 1$ a maior concentração de casos de rede com nós de dentro aparece na faixa entre os 50 a $60 \%$ de nós com oito casos (ou $27 \%$ das redes), seguido da faixa de 40 a $50 \%$, com seis casos (ou 20\%). 
Já nos casos de nós de fora, temos em t1 uma disposição mais espalhada desde os 20 até os $60 \%$ dos nós contendo cada faixa percentual de cinco a seis casos, somando um total de vinte e um casos ou $71 \%$ das redes, confirmando as médias encontradas.

\section{Localismo no t2}

Ao contrário do que foi encontrado no primeiro período, a média de nós de fora foi superior a média de nós de dentro no segundo momento, sendo $51 \%$ fora e $48 \%$ de dentro da Vila Castelo Branco ${ }^{62}$.

Da mesma forma como foi feito antes, aqui também se distribuiu os nós por faixas percentuais de dentro e fora para comparar com a média encontrada. Enquanto os nós de dentro se concentram na faixa entre os 30 a 50\%, com quatorze redes, os nós de fora se agregam na faixa superior entre 50 a $60 \%$ de nós de fora.

Deste modo, a análise do localismo dos nós evidencia uma tendência ainda que pequena de pessoas de fora do bairro compondo as redes dos entrevistados no segundo período. Mesmo a média não sendo de grande expressão dada a baixa diferença percentual entre as duas categorias dentro e fora, a concentração de casos na faixa entre os 50 e $60 \%$ de nós de fora incrementa um pouco mais esse resultado. Interessante notar que mesmo que pequena, indica também uma alteração em relação ao período anterior, quando a tendência era inversa.

\section{Localismo nos dois tempos}

Apenas três redes permaneceram com a mesma distribuição entre dentro e fora nos dois períodos, tomando os dois casos em que a rede não sofreu nenhuma alteração, e também um caso onde a rede aumentou no t2, mas, coincidentemente, manteve a mesma distribuição percentual entre dentro e fora.

No entanto, na maioria das redes pode-se perceber uma tendência de aumento de nós de fora da Vila Castelo Branco no segundo momento, passando de $44 \%$ da rede para $51 \%$ a média de nós de fora, ou seja, uma diferença de sete pontos percentuais. De fato, encontramos 10 redes com aumento do número de pessoas de fora do bairro. Nesse

\footnotetext{
${ }^{62}$ Neste caso, ocorreu a influência de $1 \%$ de nós sem classificação nesse aspecto.
} 
sentido, constata-se uma tendência de aumento de nós de fora, o que concorda com a idéia de que a menor segregação pode estar facilitando contatos com pessoas de outros locais.

Não podemos deixar de lado a informação complementar, ou seja, que os indivíduos de dentro do bairro nas redes eram mais presentes no primeiro tempo com média de $56 \%$ dos nós e diminuem sua predominância, passando a ter $48 \%$ quando o bairro deixa de ser segregado.

Esse resultado difere do encontrado por Marques (no prelo) para os pobres da cidade de São Paulo. Segundo esse autor, os indivíduos mais segregados abordados por sua pesquisa, evidenciaram uma leve tendência a ter redes com menos localismo, comparativamente com os pobres não segregados. Isso principalmente se o local de moradia considerado era de pequena escala, como é o caso da favela Vila Nova Esperança, localizada na fronteira entre São Paulo e Taboão da Serra.

De fato, os dados de Marques (no prelo) ainda que com evidência não definitiva, expõem uma tendência contrária a explorada por grande parte da literatura que trata de segregação, que entende que essa condição espacial limitaria as possibilidades relacionais oferecidas principalmente entre pobres urbanos. A explicação buscada por esse autor é que "se há efeito da segregação sobre as redes, parece operar no sentido de tornar a sociabilidade mais ampla em termos urbanos e, talvez, mais diversificada, favorecendo as redes de locais mais segregados". De forma que seus resultados evidenciam maior complexidade entre segregação e redes do que a esperada pela bibliografia.

Entretanto, os dados da Vila Castelo Branco concordam com o que diz a literatura a respeito da restrição de contatos promovida pela segregação espacial (Kaztman, 2001, por exemplo), sendo que houve menor localismo dos nós após a integração do bairro à cidade de Campinas.

\subsubsection{Diversidade da Sociabilidade}

\section{Diversidade da Sociabilidade no t1}

Em relação às esferas de sociabilidade, elas apareceram na seguinte ordem decrescente de freqüência: família; vizinhança; trabalho; igreja; amizade; 
saúde/atividades físicas e associação aparecem empatadas e, por fim, a esfera dos estudos $^{63}$.

Tabela 2 - Freqüência das esferas entre as redes dos entrevistados no t1

\begin{tabular}{|l|c|c|}
\hline Esferas & Frequência & \% de ocorrência \\
\hline Família & 29 & 96,7 \\
\hline Vizinhança & 27 & 90,0 \\
\hline Trabalho & 11 & 36,7 \\
\hline Igreja & 10 & 33,3 \\
\hline Amizade & 6 & 20,0 \\
\hline Saúde/atividade física & 4 & 13,3 \\
\hline Associação & 4 & 13,3 \\
\hline Estudos & 2 & 6,7 \\
\hline Não classificados & 7 & 23,3 \\
\hline
\end{tabular}

Fonte: levantamento próprio a partir de pesquisa de campo.

A baixíssima representação da esfera estudos em apenas dois casos, representando $6,7 \%$ das esferas encontradas, pode ser entendida a partir de dois pontos. Primeiramente devido a faixa etária dos entrevistados, uma vez que essa esfera corresponde a uma sociabilidade que pode ter sido perdida ou, ao menos, adormecida dado o longo tempo decorrido desde o período de estudo dos entrevistados aos dias atuais - fato alegado por eles próprios. Em segundo lugar, porque a escolaridade tende a ser baixa nesse grupo, com $43 \%$ dos entrevistados apresentando apenas quatro anos de estudos, correspondente a conclusão do ensino fundamental.

De toda forma, mesmo nas redes que essa esfera esteve presente ela teve pouca repercussão, tendo apenas um nó na rede do entrevistado número 30 sem nenhuma ligação com outros nós dessa rede. A entrevistada número 26, mesmo tendo uma escolaridade maior - onze anos de estudo - citou apenas 4 nós na esfera de estudos, que também não se relacionam com outros nós da rede.

\footnotetext{
${ }^{63}$ Algumas esferas foram agrupadas entre si criando grupos para facilitar a análise. No caso de igreja, ela abarca tanto a freqüência a templos religiosos, como grupo de oração e mesmo a esfera de organização da Festa de Santo Reis por uma entrevistada. Em saúde/atividades físicas estão presentes grupos de exercícios físicos gerais, futebol, médicos e/ou posto de saúde. Por fim, associação engloba a própria associação de moradores do bairro, também a Escola de Samba Rosas de Prata e a participação em atividades no Progen - ONG local.
} 
Dentre as esferas citadas pelos entrevistados é possível assinalar que tanto a família quando a vizinhança são esferas que se destacam das demais. Além da alta freqüência nas redes desses indivíduos, ainda são as maiores esferas em número de nós em $63 \%$ das redes (dezenove redes) no caso da vizinhança e $23 \%$ (sete redes) no caso da família, além de mais dois casos em que elas empatam juntas como sendo as maiores esferas. A única outra esfera que aparece com maior número de nós é a esfera trabalho em apenas uma das redes e com a mesma quantidade de nós que a esfera da vizinhança $^{64}$.

Ainda que seja difícil traçar tipos de sociabilidade como fez Marques (2007 e no prelo) devido à pequena amplitude desta amostra, é possível agrupar as redes de acordo com similaridades entre a distribuição das sociabilidades. Foi feito o exercício de agrupar as redes em perfis de sociabilidade de acordo com as esferas que mais se destacaram nelas ${ }^{65}$. Nesse primeiro período, encontramos seis perfis de sociabilidade como vemos no quadro a seguir:

Tabela 3 - Perfis de sociabilidade no t1

\begin{tabular}{|l|c|}
\hline Perfis & Freqüência \\
\hline Família + vizinhança & 13 \\
\hline Família + vizinhança + trabalho & 4 \\
\hline Vizinhança & 3 \\
\hline Família & 2 \\
\hline Família + trabalho & 1 \\
\hline Família + amizade & 1 \\
\hline
\end{tabular}

Fonte: levantamento próprio a partir de pesquisa de campo.

Contudo é preciso destacar que esse agrupamento em perfis não significa que as redes estão restritas a essas esferas de sociabilidade, mas apenas que elas predominam dentre as outras esferas presentes nessas redes, conformando um certo padrão.

Confirmando os dados anteriores, tanto a família quanto a vizinhança são esferas fortemente presentes, sejam sozinhas, juntas entre si ou com outras esferas. É

\footnotetext{
${ }^{64}$ No entanto, é preciso ponderar sobre a captação do atributo de esfera de sociabilidade entre os entrevistados. Das 30 redes, seis apresentam alguns nós não classificados (missing), apesar da grande maioria dos nós que as compõem apresentar esse atributo. Dessa forma, desconsideramos os nós não classificados, entendendo que esse procedimento não afetou substancialmente o resultado da análise da rede. Apenas uma das redes não possui nenhuma classificação quanto às esferas, o quê inviabiliza sua análise nesse aspecto. Nesse caso, descontamos uma rede do total para o cálculo das porcentagens.

${ }^{65}$ Para essa análise o procedimento foi considerar as esferas que tivessem mais de $20 \%$ dos nós de cada rede. No entanto, ao contrário do que foi realizado anteriormente, para o agrupamento das sociabilidades foi necessária a subtração das redes que apresentassem nós não classificados, o que corresponde ao desconto de seis redes das trinta elaboradas pela pesquisa.
} 
importante notar também a presença da sociabilidade do trabalho e da amizade, compondo com as esferas da família e vizinhança e também uma rede apenas com a família. Essa análise se tornará mais interessante quando comparados os resultados entre os tempos, o quê será realizado mais adiante.

$\mathrm{Na}$ análise sobre situações de precariedade social, Marques (2007) encontrou relação direta entre as redes cujo perfil é composto por sociabilidade focada principalmente na família e vizinhança com as situações mais precárias ${ }^{66}$. Os resultados desse autor indicam que a sociabilidade nas redes é uma importante dimensão condicionante das situações sociais dos indivíduos pobres.

\section{Diversidade da Sociabilidade no t2}

Em relação às esferas de sociabilidade, elas apareceram quase na mesma ordem decrescente de freqüência que no primeiro período: família, vizinhança, trabalho, igreja, saúde/atividades físicas, amizade, associação e estudos.

Nesse período as esferas com maior quantidade de nós além de maior ocorrência entre as redes são também a vizinhança e família, em $58 \%$ e $33 \%$ dos casos respectivamente. Apenas em duas redes a esfera saúde/ atividades físicas apareceu como a com maior número de nós.

É interessante assinalar que quase metade das redes teve um acréscimo de uma ou mais esferas de sociabilidade em relação ao primeiro período. As sociabilidades criadas foram no âmbito da saúde/ atividades físicas, igreja e trabalho principalmente, mas também apareceram citações das esferas amizade e associação.

Tabela 4 - Freqüência das esferas entre as redes dos entrevistados no t2

\begin{tabular}{|c|c|cc|}
\hline Esferas & Frequência & $\begin{array}{l}\text { \%o de ocorrência entre os } \\
\text { entrevistados }\end{array}$ & \\
\hline Família & 29 & 96,7 & \\
\hline Vizinhança & 27 & 90,0 & \\
\hline Trabalho & 15 & 50,0 & \\
\hline Igreja & 14 & 46,7 & continua \\
\hline
\end{tabular}

66 Marques (2007) considerou quatro tipos de precariedades: familiar, habitacional, de renda e de trabalho; definindo precariedade social a situação na qual o indivíduo apresenta ao menos duas condições de precariedade dentre essas quatro. 


\begin{tabular}{|c|c|c|}
\hline $\begin{array}{c}\text { continuação } \\
\text { Esferas }\end{array}$ & Frequência & $\begin{array}{l}\text { \% de ocorrência entre os } \\
\text { entrevistados }\end{array}$ \\
\hline Amizade & 8 & 26,7 \\
\hline Associação & 7 & 23,3 \\
\hline Estudos & 2 & 6,7 \\
\hline Não classificados & 7 & 23,3 \\
\hline
\end{tabular}

Fonte: levantamento próprio a partir de pesquisa de campo.

Com relação aos perfis de sociabilidade, vemos uma mudança em relação ao primeiro tempo, pela variação dos seus tipos. Apesar da família e a vizinhança continuarem se destacando como as principais esferas, outras formas de sociabilidade ganharam mais nós nesse período.

Agora, além do trabalho e amizade, saúde/atividade física e igreja passam a compor as sociabilidades dos moradores da Vila Castelo Branco. Vemos assim que há mais diversidade da sociabilidade nesse momento, apesar do predomínio da família e vizinhança.

Tabela 5 - Perfis de sociabilidade no t2

\begin{tabular}{|l|l|}
\hline Perfis & Freqüência \\
\hline Família + vizinhança & 12 \\
\hline Família & 2 \\
\hline Família + vizinhança + trabalho & 2 \\
\hline Família + vizinhança + igreja & 2 \\
\hline Família + saúde/atividade física & 2 \\
\hline Vizinhança & 2 \\
\hline Vizinhança + trabalho & 1 \\
\hline Família + amizade & 1 \\
\hline
\end{tabular}

Fonte: levantamento próprio a partir de pesquisa de campo.

\section{Diversidade da Sociabilidade nos dois tempos}

Retomando o que já foi exposto acima e comparando os dados dos dois períodos, as esferas de sociabilidade sempre foram mais variadas no segundo tempo para cada entrevistado. Isto é, em treze casos, os entrevistados citaram novas esferas no segundo período, esferas essas que não existiam em suas redes no t1. Em alguns casos, a própria criação da esfera serviu como marco pessoal utilizado entre os dois períodos. Por exemplo, quando o indivíduo passa a freqüentar o grupo de exercícios da terceira idade. 
Na comparação entre os períodos, a esfera da amizade teve mais destaque no $t 1$ que no t2, quando a esfera saúde/atividades físicas a supera em termos de freqüência entre os entrevistados. Tal dado é coerente com a idéia das esferas criadas no segundo período terem relação com a faixa de idade, tanto por aumentar os cuidados com a saúde, quanto pela tendência de possível queda da sociabilidade entre amigos nessa faixa etária.

Tabela 6 - Esferas em t1 e t2 em ordem decrescente de freqüência entre os entrevistados.

\begin{tabular}{|c|c|}
\hline T1 & T2 \\
\hline Família & Família \\
\hline Vizinhança & Vizinhança \\
\hline Trabalho & Trabalho \\
\hline Igreja & Igreja \\
\hline Amizade & Saúde \\
\hline Saúde = Associação & Amizade \\
\hline Estudos & Associação \\
\hline & Estudos \\
\hline
\end{tabular}

Fonte: levantamento próprio a partir de pesquisa de campo.

Tabela 7 - Comparação da ocorrência das esferas entre os períodos

\begin{tabular}{|c|c|c|}
\hline & T1 & $\mathbf{T 2}$ \\
\hline Esferas & \begin{tabular}{|ll}
$\%$ & de \\
ocorrência
\end{tabular} & $\begin{array}{ll}\% & \text { de } \\
\text { ocorrência }\end{array}$ \\
\hline Família & 96,7 & 96,7 \\
\hline Vizinhança & 90 & 90 \\
\hline Trabalho & 36,7 & 50 \\
\hline Igreja & 33,3 & 46,7 \\
\hline Amizade & 20 & 26,7 \\
\hline Saúde/Atividades físicas & 13,3 & 30 \\
\hline Associação & 13,3 & 23,3 \\
\hline Estudos & 6,7 & 6,7 \\
\hline Não classificados & 23,3 & 23,3 \\
\hline
\end{tabular}

Fonte: levantamento próprio a partir de pesquisa de campo. 
Comparando os dois quadros de freqüência das esferas, percebemos que apesar da família e vizinhança serem indubitavelmente as esferas com maior ocorrência em ambos os períodos, é possível observar um crescimento de outras esferas. Além dessas duas e com exceção dos estudos - que manteve a mesma porcentagem de ocorrência todas as demais esferas apareceram em mais redes no segundo período.

Essa maior diversidade das esferas de sociabilidade no segundo momento considerado indica que a integração espacial da Vila Castelo Branco pode estar facilitando maior contato com diferentes mundos sociais para seus moradores. No entanto, é preciso ponderar que a existência de várias esferas em si não determina que o indivíduo faça uso pleno das possibilidades disponíveis. De fato, o dado captado informa sobre a existência dessas possibilidades, mas seria preciso aprofundar na pesquisa para afirmar com mais segurança quais são as trocas estabelecidas entre os indivíduos.

De toda forma, mesmo com o aumento da variabilidade da sociabilidade, é patente a predominância de vínculos nas esferas da família e vizinhança em ambos os períodos. Contudo, apesar da potencialidade de redundância dos contatos de acordo com o princípio de ação homofilica já explorado, Almeida e D’Andrea (2005) e Marques (2007) assinalaram que esse tipo de sociabilidade pode ser relevante para os indivíduos pelo fornecimento de apoio e ajuda em certas circunstâncias.

Ainda que os dados não permitam afirmações a esse respeito, seria interessante verificar a existência desse tipo de benefício para a população da Vila Castelo Branco. Vínculos fortes como a família e vizinhança podem fornecer apoios importantes, principalmente para os mais idosos como os entrevistados. Nesse caso, os benefícios podem vir tanto em forma de socorro em caso de doença, bem como pela própria convivência facilitada pela proximidade, importante para quem não tem compromissos profissionais e dispensando grandes locomoções e gastos com transporte para visitas.

Com relação aos perfis, além da já destacada importância das esferas da família e vizinhança, mesmo quando compondo com outras sociabilidades, é importante observar quais foram as alterações entre os períodos. Notou-se principalmente a existência de três novos perfis de sociabilidade, incluindo a igreja e a saúde/atividades físicas nas esferas mais presentes entre os entrevistados, ampliando a diversidade das sociabilidades no segundo momento.

Mesmo que o perfil vizinhança + trabalho tenha tido apenas uma ocorrência, ainda assim indica a tendência de diversificação da sociabilidade entre os entrevistados 
atualmente. De maneira semelhante o perfil família + trabalho também esteve presente em apenas uma das redes no t1, mas a sua existência nesse período tem o mesmo papel de marcar a diversidade.

Ainda que a freqüência dos perfis não seja muito elevada, a sua alteração pode ser notada. Além disso, a existência de outras esferas de sociabilidade na composição das redes desses indivíduos contrapõe o esperado pela bibliografia para essa faixa etária, enquanto que, por outro lado, concorda com as hipóteses que atribuem restrição de diversidade dada pela segregação espacial.

Tabela 8 - Comparação dos perfis de sociabilidade entre os dois períodos

\begin{tabular}{|l|c|c|}
\hline \multicolumn{1}{|c|}{ Perfis } & Freqüência no t1 & Freqüência no t2 \\
\hline Família + vizinhança & 13 & 12 \\
\hline Família + vizinhança + trabalho & 4 & 2 \\
\hline Vizinhança & 3 & 2 \\
\hline Família & 2 & 2 \\
\hline Família + vizinhança + igreja & 0 & 2 \\
\hline Família + saúde & 0 & 1 \\
\hline Família + amizade & 1 & 1 \\
\hline Vizinhança + trabalho & 0 & 0 \\
\hline Família + trabalho & 1 & 2 \\
\hline
\end{tabular}

Fonte: levantamento próprio a partir de pesquisa de campo.

\subsubsection{Esferas de sociabilidade e localismo}

\section{Esferas e localismo no t1}

Analisando a distribuição dos nós entre dentro e fora em relação com a distribuição por esferas de sociabilidade, foi possível identificar aquelas que mais agregaram nós de fora.

No primeiro período a família foi a esfera que contribuiu com mais nós de fora em dezenove das redes pesquisadas. Além dessas, mais duas redes apresentaram a família empatada com o trabalho como esferas com maior quantidade de pessoas de fora do bairro. Esse resultado indica que os membros da família que compõem as redes dos entrevistados não são somente aqueles que moram na mesma casa, abarcando uma gama maior que se localiza inclusive em outros bairros da própria cidade ou mesmo em outras cidades. 
Esse resultado merece destaque por ser distinto do que é geralmente esperado e do que foi encontrado por Marques (2007 e no prelo). Aprofundaremos na sua interpretação na seção seguinte, comparando com os demais dados encontrados.

A vizinhança apareceu com maior porcentagem de nós de fora em três redes, seguida de trabalho - só essa esfera em dois casos e mais os dois já citados em conjunto com a família. Em apenas um caso a igreja apareceu como esfera com maior quantidade de nós de fora do bairro.

No entanto, considerando os nós de dentro da Vila Castelo Branco, a esfera de sociabilidade que mais contribuiu nesse sentido na maioria das redes foi a vizinhança. Em mais de $79 \%$ dos casos, essa foi a principal esfera composta por nós do próprio bairro nesse período. Nas redes restantes, a família apareceu como segunda esfera com mais nós de dentro, sendo coincidente com a vizinhança em dois casos e com a sociabilidade da amizade em uma rede.

\section{Esferas e localismo no t2}

No segundo período, a conjugação da análise da distribuição dos nós entre as esferas e o localismo também revelou que a família se manteve como a principal fonte de pessoas de fora do bairro com dezoito redes apresentando essa característica. Depois, com três casos cada, apareceram a vizinhança e o trabalho como sociabilidades com mais pessoas de fora da Vila Castelo Branco. Por fim, com dois casos cada, a igreja e a saúde/atividade física foram as esferas que se destacaram com mais nós de fora.

Com relação aos nós de dentro, a esfera da vizinhança foi novamente a que mais se destacou nesse sentido. Também nesse período, mais de 79\% dos casos teve essa esfera como a mais composta por nós de dentro do bairro em questão. Nas demais redes, a família apareceu como esfera com maior quantidade de nós de dentro, mas mesmo assim, foi combinada com a vizinhança em um caso e com a esfera da amizade em mais um caso. 


\section{Esferas e localismo nos dois tempos}

Na maioria das redes, ou seja, vinte e um casos, as mesmas esferas foram as que apresentaram o maior número de nós nos dois tempos. Essas esferas, como já apresentado acima, foram predominantemente a família e a vizinhança. No entanto, se são as maiores esferas e o resultado geral indicou um aumento dos nós de fora, é mesmo de se esperar que sejam essas as esferas responsáveis por maior quantidade de nós de fora.

Não é de se estranhar também que em dezoito redes a mesma esfera que trouxe mais nós de fora no primeiro período foi a mesma do segundo tempo, coincidindo como a principal esfera de sociabilidade com nós de fora ao longo da mudança espacial. Como exemplo, tomo a rede da entrevistada 21 - apresentada acima como exemplo de grande crescimento geral - na qual a família foi a responsável por fornecer mais de $40 \%$ dos nós de fora nos dois períodos.

O trabalho foi a terceira esfera de sociabilidade em quantidade de nós de fora do bairro, coincidentemente também foi a terceira esfera em termos de número de nós nos dois períodos.

Com relação aos nós de dentro, a vizinhança se destacou nos dois períodos como a principal esfera responsável por ser constituída por nós de dentro. Fato de certo modo esperado dada a forte relação da concepção dessa esfera com a moradia no bairro.

\subsection{Síntese dos resultados}

Comparando os dados de t1 e t2 e tomando esses períodos como correspondentes das alterações da condição espacial da Vila Castelo Branco, pode-se dizer que quando os moradores desse bairro eram segregados suas redes eram menores e mais locais do que suas redes atuais.

Em termos de homofilia de sexo, alterações muito pequenas foram observadas para que se possa fazer afirmações sobre influência dessa mudança espacial nesse aspecto. Há ainda o pequeno número de homens presentes na amostra, o que torna ainda mais necessária a ponderação desse dado como representativo da questão em foco.

A tabela abaixo sumariza os dados nos dois períodos, facilitando a comparação entre eles. 
Tabela 9 - Comparação das médias entre os dois períodos

\begin{tabular}{|c|l|r|r|}
\cline { 2 - 4 } \multicolumn{1}{c|}{} & T1 & \multicolumn{1}{c|}{ T2 } \\
\hline \multirow{4}{*}{ Tamanho } & Número de nós & 24,7 & 50,8 \\
\cline { 2 - 4 } & Número de vínculos & 63,27 & 150,4 \\
\cline { 2 - 4 } & Diâmetro* & 5,2 & 5,8 \\
\cline { 2 - 4 } & Densidade & $13,86 \%$ & $9,4 \%$ \\
\hline \multirow{3}{*}{ Homofilia de sexo } & Mulheres & $71 \%$ & $69 \%$ \\
\cline { 2 - 4 } & Homens & $59 \%$ & $61 \%$ \\
\cline { 2 - 4 } & Total & $68 \%$ & $67 \%$ \\
\hline \multirow{2}{*}{ Localismo } & Dentro & $56 \%$ & $48 \%$ \\
\cline { 2 - 4 } & Fora & $44 \%$ & $51 \% * *$ \\
\hline
\end{tabular}

Fonte: levantamento próprio a partir de pesquisa de campo.

Nota: * Número de passos. **O localismo dos nós não soma $100 \%$ no t2, pois neste caso, temos $1 \%$ de nós sem classificação nesse aspecto.

Além das redes serem maiores e menos locais atualmente, houve também um importante aumento da freqüência de certas sociabilidades entre os entrevistados. Interessante esse aumento especialmente por dois motivos. Primeiramente, por que mesmo que outras esferas tenham aparecido em mais redes no t2, essas não alcançaram a dimensão que a família e a vizinhança têm entre os entrevistados.

A predominância das esferas de sociabilidade da família e da vizinhança indica pouca alteração de seus papéis como fatores de composição das redes. Pode-se dizer isso porque as esferas da família e vizinhança se mantêm em destaque em vários dos aspectos analisados aqui, liderando as esferas mais fortes na sociabilidade dos indivíduos pesquisados. A esfera do trabalho ocupa a mesma terceira posição nos dois períodos, não fazendo distinção nem mesmo pelo fator ciclo de vida.

No entanto, e daí vem outra razão da importância dessa constatação, o crescimento da freqüência de outras esferas além da família e vizinhança evidenciou intensa atividade relacional dos indivíduos no segundo momento. Isso inclusive contraria a tendência dada pelo ciclo de vida, como já comentado anteriormente. Nesse sentido, o simples fato do aumento observado em outras esferas aponta maior diversificação de sociabilidade para mais indivíduos dentre os entrevistados.

Contudo, esse resultado pode indicar que a existência ou importância de cada esfera de sociabilidade não sofreu grande alteração com a mudança espacial, ao contrário do que foi percebido em relação ao localismo dos nós. O aumento da quantidade de pessoas de fora das redes de modo geral, seja de que esfera for, é marcante e se destaca como importante alteração de um período para outro. 
Nesse aspecto vale aprofundar na relação entre o destaque das esferas da família e vizinhança com o localismo dos nós. Na Vila Castelo Branco, é bastante comum encontrar várias gerações de uma família morando na mesma casa ou em cômodos adjacentes (os chamados “puxadinhos"). Devido a esse aspecto, poderíamos esperar certa concentração dos nós dessa esfera dentro do mesmo bairro dos entrevistados inclusive por estarem morando na mesma casa. No entanto, essa hipótese não se confirmou, pois a esfera de sociabilidade da família se destacou na grande maioria das redes (dezenove redes no t1 e dezoito no t2) como a esfera com maior quantidade de nós de fora.

Nesse sentido, é complicado fazer afirmações sobre uma relação imediata entre as pessoas classificadas como sendo parte da sociabilidade da família pelo ego e a mudança espacial. Isso ocorre até mesmo por se tratar de uma esfera de sociabilidade que pode ter pouca relação com o local de moradia dos indivíduos em questão, uma vez que se trata de um tipo de ligação forte entre as pessoas que pode transcender fronteiras espaciais, havendo motivações para a manutenção dos laços diferentes das que regem a dinâmica de laços de trabalho ou amizade, por exemplo.

Ainda que com menor representatividade entre as redes pesquisadas (apenas três casos em ambos os períodos), a vizinhança foi a segunda esfera que agregou mais novos nós de fora no segundo período. Por estabelecer uma relação mais estreita com o local de moradia do que a família, se a vizinhança aponta pessoas que moram tanto na Vila Castelo Branco como nos bairros vizinhos, é importante sublinhar que os nós de fora podem vir justamente desses bairros que foram construídos e cresceram como parte do processo de integração da Vila Castelo Branco. Esse ponto indica fortemente a influência da mudança espacial nas redes.

Por outro lado, a vizinhança se configurou como a esfera de sociabilidade que mais teve nós de dentro do bairro. Resultado bastante aceitável, pois mesmo que a relação entre vizinhança e os limites do bairro não seja algo imediato, ainda assim é uma idéia que tem forte conotação territorial.

No entanto, independente da esfera de sociabilidade, o resultado geral obtido se alinha com a argumentação de que a segregação espacial, estaria restringindo a diversidade e localismo dos contatos de fora do bairro do ego em questão. Seguindo a lógica desse argumento, a integração espacial da Vila Castelo Branco facilitaria a obtenção de vínculos com pessoas de fora do bairro, o que se confirmou com os dados encontrados. 
Considerando ainda que o atributo de localismo do nó é o que menos sofre influência na captação dos dados nos dois períodos, observa-se que o localismo dos nós sofre sim influência da segregação e da mudança da condição espacial do bairro de estudo. $\mathrm{O}$ que pode levar a conclusão de que a integração espacial do bairro à cidade estaria reforçando o contato com pessoas de fora, apontando também maior integração social dos moradores da Vila Castelo Branco.

De acordo com o entendimento dos benefícios relacionais que essa diversificação das redes encontradas no segundo período pode trazer para os indivíduos é possível pensar que a mudança espacial teria beneficiado ou ao menos aumentado o leque de bens passíveis de serem acessados pelos moradores da Vila Castelo Branco. 


\section{Considerações finais}

O objetivo deste trabalho foi a verificação do impacto da mudança espacial sobre as redes sociais dos moradores da Vila Castelo Branco, bairro popular da cidade de Campinas. O processo de passagem de uma situação de segregação espacial no início da ocupação do bairro para a integração atual repercutiu na rede de seus moradores de diversas formas.

De modo geral, as redes sociais dos moradores do bairro estudado eram menores, mais locais e menos variadas em termos de sociabilidade no período em que este se encontrava segregado espacialmente. Com a mudança da sua condição espacial pelos processos diversos que desembocaram em investimento em infra-estrutura e expansão da cidade, as redes de seus moradores aumentaram de tamanho, contatos com pessoas de fora do bairro foram estabelecidos e novas esferas de sociabilidades passaram a fazer parte do mundo social desses indivíduos.

A condução da pesquisa levou em consideração que pensando em termos de pobreza urbana, o espaço onde se é pobre oferece certas condições positivas e/ou negativas de acesso à bens e serviços. As hipóteses levantadas pela literatura são de que o espaço segregado seria mais negativo, com maiores restrições, seja por sua distância, seja pela própria precariedade de infra-estrutura e serviços que caracteriza muitos espaços segregados. O espaço não segregado ou integrado, se preferir, seria mais facilitador para o acesso dos indivíduos a melhores condições de vida, tanto pela proximidade de locais mais bem providos, como pela melhor oferta de recursos no próprio local.

As redes sociais dos indivíduos, por outro lado, podem também se constituir em meios de constrangimento e oportunidades relacionais, com potencialidade para se traduzir em meio de fluidez de recursos materiais e imateriais em proveito dos sujeitos em questão. O tamanho, a variabilidade da sociabilidade e o localismo das redes foram as chaves elencadas para observar o comportamento das redes sociais dos moradores da Vila Castelo Branco sobre a influência de uma mudança espacial.

Essa questão remete ao fato de como a segregação e suas possíveis conseqüências relacionais se reforçam ainda mais com os dados levantados até o momento do que a simples integração espacial. Isto é, no contraponto entre as duas situações delimitou-se mais claramente a atuação das restrições do primeiro momento do que propriamente as oportunidades obtidas com a integração da Vila Castelo Branco 
atualmente. Apesar de a intenção ser justamente essa comparação para delinear as vantagens e desvantagens de uma situação espacial frente a outra, a definição das restrições sociais dada pela segregação não necessariamente se traduz imediatamente numa situação contrária de grandes benefícios relacionais. Isso principalmente em termos relacionais e pensando em dinâmicas de produção e reprodução da pobreza.

Para entender melhor esse processo são necessários mais estudos sobre o que a nova situação teria beneficiado os moradores do bairro em questão ou mesmo em outros locais que passaram por processo semelhante.

Um dos resultados paradigmáticos nessa questão e que merece destaque diz respeito ao localismo dos vínculos estabelecidos pelos entrevistados. A limitação de laços inicialmente dada pela segregação foi superada e os moradores do bairro estudado estabeleceram mais contatos com quem mora fora. Resta saber até onde vão esses vínculos e que tipo de recursos diferenciais podem haver nesses outros locais ou se seriam locais com características semelhantes às da Vila Castelo Branco atualmente. Por exemplo, se forem apenas vínculos de bairros imediatamente vizinhos, será que isso teria realmente trazido grande heterofilia para os sujeitos? Por outro lado, se forem de bairros ou outros locais semelhantes, é possível perguntar se a mera expansão dessas redes não pode em si mesma ser um mecanismo de abertura de possibilidades e acesso a benefícios. Acredita-se que essa hipótese não deva ser descartada sem verificação empírica mais detalhada.

Dado os limites desse estudo, não se pode afirmar que a diversidade de contatos bem como de localização destes tenha garantido a saída da pobreza dos moradores da Vila Castelo Branco. O que se conclui dos dados levantados pela pesquisa é que a proximidade espacial, disseminação de boas condições urbanas, incluindo desde infraestrutura até serviços públicos e privados favoreceu o estabelecimento de relações sociais mais diversas e amplas que as possíveis em espaço segregado. De forma que foram apresentados dados empíricos que indicam que a segregação restringe certas oportunidades relacionais, tal como a bibliografia esperava.

Sendo as redes um meio de fluidez de recursos e, portanto de impacto sobre a pobreza, o entendimento de seu funcionamento - em especial em relação a outros mecanismos como a segregação - se mostra relevante para o desenvolvimento de medidas de combate.

Por outro lado, ainda que a construção de forma segregada da Vila Castelo Branco fora resultado de política habitacional realizada pelo governo ditatorial dos anos 
1960-80, não é prática exclusiva desse tipo de governo ou período histórico brasileiro. Exemplos de políticas segregacionistas podem ser encontrados em outros locais ainda hoje. Evidenciar os efeitos que a segregação espacial pode ter sobre as condições de vida dos indivíduos - e a influência sobre as redes é apenas um dos aspectos - é uma das formas de fomentar debates e políticas públicas que combatam essa prática.

Ainda que seja necessário um maior aprofundamento nas dinâmicas relacionais como meio de pensar maneiras para o combate da pobreza urbana, constatar que a segregação espacial é um mecanismo de efetiva restrição social é mais um ponto na argumentação em favor de medidas que evitem a alocação de população homogênea no espaço e o isolamento social dos pobres urbanos. Colocar o problema em pauta e enriquecer os argumentos nesse sentido é uma das formas de incrementar o desenvolvimento de processos que afetem diretamente a desigualdade social, ainda persistente no nosso país. 


\section{REFERÊNCIAS BIBLIOGRÁFICAS}

ALMEIDA, Ronaldo \& D'ANDREA, Tiaraju. "Estrutura de oportunidades em uma favela em São Paulo”. In: MARQUES, E. \& TORRES, H. (orgs.). São Paulo - segregação, pobreza e desigualdades sociais. São Paulo: Editora Senac São Paulo, 2005.

ANTUNES, Denise Castanho. Memórias das transformações de grupos comunitários como forma de favorecimento do envelhecimento bem-sucedido. Dissertação de Mestrado apresentada ao Departamento de Gerontologia na Faculdade de Educação - Unicamp. Campinas, 2006.

ARANTES NETO, Antonio Augusto. Paisagens paulistanas: transformações do espaço público. Campinas-SP: Editora da Unicamp; São Paulo: Imprensa Oficial, 2000.

ARRETCHE, MARTA. Estado e Mercado na Provisão Habitacional: Três Modelos de Política. Dissertação de Mestrado apresentada ao Instituto de Filosofia e Ciências Humanas - IFCH/Unicamp, 1990.

BAENINGER, Rosana. Espaço e Tempo em Campinas: Migrantes e Expansão do Pólo Industrial Paulista. Campinas: Área de Publicações CMU/UNICAMP, 1996.

BAENINGER, R. \& GONÇALVES, Renata Franco de Paula "Novas espacialidades no processo de urbanização: a Região Metropolitana de Campinas". In: Anais do XII Encontro Nacional de Estudos populacionais da ABEP, Caxambu, Anais..., v.1, Belo Horizonte: ABEP, 2000.

BARNES, John A. "Class and Committees in a Norwegian Island Parish". London: Human Relations, vol. VII, no. 1, 1954.

BICHIR, Renata Mirandola. Segregação e acesso a políticas públicas no município de São Paulo. Dissertação de Mestrado apresentada ao Departamento de Ciência Política - FFLCH, USP, 2006.

BLOKLAND, Talja. Urban Bonds - Social Relationships in an Inner City Neighbourhood. Polity Press, 2003.

BOSI, Ecléa. Memória e Sociedade: lembranças de velhos. São Paulo: T.A. Queiroz, Editor, 1979.

BOURDIEU, Pierre. "Efeitos de lugar". BOURDIEU, Pierre (coord.). A miséria do mundo. Petrópolis, Rio de Janeiro: Vozes, 2003.

CAIADO, Maria Célia Silva \& PIRES, Maria Conceição Silvério Pires. Campinas Metropolitana: transformações na estrutura urbana atual e desafios futuros". 
In: CUNHA, José Marcos Pinto (org.) Novas Metrópoles Paulistas População, vulnerabilidade e segregação. Campinas: Núcleo de Estudo da População - NEPO/ Unicamp, 2006.

CAIADO, Aurílio S. C.; PIRES, Maria, C. S.; SANTOS, Sarah M. M. dos \& MIRANDA, Zoraide A. I. "Município de Campinas". In: CANO, Wilson \& BRANDÃO, Carlos A. (coords). A Região Metropolitana de Campinas Urbanização, economia, finanças e meio ambiente. Campinas, SP: Editora da Unicamp, 2002.

CALDEIRA, Teresa P. R. "Enclaves fortificados: a nova segregação urbana". Novos Estudos no 47, março, São Paulo: Cebrap, 1997.

. Cidade de muros: crime, segregação e cidadania em São Paulo. São Paulo: Ed. 34/ Edusp, 2000.

CAZOLlATO, José Donizete. Os bairros como instância territorial local contribuição metodológica para o caso de São Paulo. Dissertação de Mestrado apresentado ao Departamento de Geografia Humana - FFLCH/ Usp, 2005.

CUNHA, José Marcos Pinto da \& OLIVEIRA, Antonio Augusto Bitencourt. "População e Espaço Intra-urbano em Campinas". In: HOGAN, Daniel; BAENINGER, Rosana; CUNHA, José Marcos Pinto da \& CARMO, Roberto Luiz do (orgs.). Migração e Ambiente nas Aglomerações Urbanas. Campinas: Núcleo de Estudos de População/UNICAMP, 2001.

CUNHA, José Marcos Pinto da; JAKOB, Augusto Eichman; JIMÉNEZ, Maren Andréa \& TRAD, Isabela Luhr. "Expansão metropolitana, mobilidade especial e segregação nos anos 90: o caso da RM de Campinas". In: Cunha, José Marcos Pinto da (org.). Novas Metrópoles Paulistas - População, vulnerabilidade e segregação. Campinas: Núcleo de Estudo da População NEPO/ Unicamp, 2006.

EMIRBAYER, Mustafa. "Manifesto for a Relational Sociology". New School for Social Research. AJS Volume 103, number 2, September 1997.

FERRAND, Alexis. "Las comunidades locales como estructuras meso". In: REDES Revista hispana para el análisis de redes sociales. Vol. 3, \#4, sept-nov. 2002. http://revista-redes.rediris.es, 2002.

FERRAND, Alexis; MOUNIER, Lise e DEGENNE, Alain . "The Diversity of Personal Networks in France: Social Stratification and Relational Structures". In: WELLMAN, Barry. Networks in the Global Village. Boulder. CO: Westview Press, 1996.

GONÇALVES, José Roberto. Espaço, Tempo e Memória, recompondo a trajetória das vilas populares em Campinas: o exemplo da Vila Castelo Branco. Dissertação de Mestrado apresentada ao Instituto de Artes e Multimeios da Unicamp. Campinas, 2002. 
GOULD, Roger. "Multiple Networks and mobilization in the Paris Commune (1871)". In: American Sociological Review. Vol. 56, p. 716-729, 1991.

GRANOVETTER. Mark. "The strength of weak ties". In: American Journal of Sociology. Vol. 78, no. 6, 1973.

HANNEMAN, Robert A. e RIDDLE, Mark. Introduction to social network methods. Riverside, CA: University of California, Riverside. Online in: http://faculty.ucr.edu/ hanneman/nettext/C8_Embedding.html, 2005.

KAZTMAN, Rubén. "Seducidos y abandonados: el aislamiento social de los pobres urbano". In: Revista de La Cepal, 75, diciembre de 2001.

KLIJN, E. "Redes de Políticas Públicas: una visión general". Disponível no site http: revista-redes.rediris.es/webredes/textos/Complex.pdf, 1998.

KNOKE, David. "Politics in structural perspective". In: Political Networks: the structural perspective. New York: Cambridge University Press, 1990.

KNOKE, David e KUKLINSKI, James H. Network analysis. Beverly Hills, Calif.: Sage, 1982.

KOWARICK, Lúcio. Capitalismo e Marginalidade na América Latina. Rio de Janeiro, Paz e Terra, 1977.

Escritos urbanos. São Paulo: Editora 34, 2000.

"Viver em risco - sobre a vulnerabilidade no Brasil urbano". Novos Estudos Cebrap, São Paulo, no 63, julho de 2002.

LAGO, Luciana Côrrea. Avaliação crítica dos trabalhos sobre segregação residencial urbana - São Paulo e Rio de Janeiro. In: www.ippur.ufrj.br/observatorio/textos.htm, sem data.

LAVAlLE, Adrian \& CASTELlO, Graziela \& BICHIR, Renata Mirandola. Os Bastidores da Sociedade Civil - Protagonismos, Redes e Afinidades no Seio das Organizações Civis. Centro Brasileiro de Análise e Planejamento CEBRAP. São Paulo, 2006.

MANFREDO, Maria Tereza. Desigualdades e produção do espaço urbano: o caso de Hortolândia na Região Metropolitana de Campinas. Dissertação de mestrado apresentada ao departamento de Sociologia do Instituto de Filosofia e Ciências Humanas - IFCH/ UNICAMP. Campinas, 2007.

MARCUSE, Peter. "Enclaves sim; guetos, não: a segregação e o Estado". Espaço \& Debates, no. 45 - Segregações Urbanas, 2004.

MARQUES, Eduardo. Estado e redes sociais: Permeabilidade e coesão nas políticas urbanas no Rio de Janeiro. Rio de Janeiro: Revan/Fapesp, 2000. 
"Elementos conceituais da segregação, da pobreza urbana e da ação do Estado". In: MARQUES, E. \& TORRES, H. (orgs.). São Paulo segregação, pobreza e desigualdades sociais. São Paulo: Editora Senac São Paulo, 2005.

"Redes Sociais e Poder no Estado Brasileiro: aprendizados a partir de políticas urbanas". Revista Brasileira de Ciências Sociais - RBCS, vol. 21, no. 60, 2006.

Redes sociais e pobreza em São Paulo. Tese de livre-docência apresentada ao Departamento de Ciência Política da USP, 2007.

Redes sociais, segregação e pobreza em São Paulo. (no prelo).

MARQUES, Eduardo Cesar e BICHIR, Renata Mirandola. "Estado e espaço urbano Revisitando criticamente as explicações correntes sobre as políticas estatais urbanas: Padrões espaciais de ação estatal na infra-estrutura urbana em São Paulo 1978/1998". Revista de Sociologia e Política, n. 15, pp. 9-30. 2001.

"Investimentos públicos, infra-estrutura urbana e produção da periferia de São Paulo". Revista Espaço e Debates, nº 42, pp. 9-30, 2002.

MAYER, Adrian C. "A importância dos 'quase-grupos' no estudo das sociedades complexas". IN: FELDMAN-BIANCO, Bela (orgs.). Antropologia das Sociedades Contemporâneas - Métodos. São Paulo: Global, 1987.

MISCHE, Ann \& WHITE, Harrison. "Between Conversation and Situation: Public Switching Dynamic across Network Domains". In: Social Research, setembro de 1998.

NÚCLEO DE ESTUDOS DE POPULAÇÃO - NEPO e NÚCLEO DE ECONOMIA SOCIAL, URBANA E REGIONAL - NESUR/IE. Campinas Metropolitana - Diversidades Sócio-Espaciais. Campinas: Universidade Estadual de Campinas, 2004.

PADGETT, John F. e ANSELL, Christopher K. "Robust action and the rise of the Medici, 1400 - 1434”. The American Journal of Sociology [AJS], 98, 1993.

PAVEZ, Thaís Regina. Ação pública e transformação de vínculos sociais em uma comunidade segregada. Trabalho apresentado no $5^{\circ}$ encontro da ABCP em Belo Horizonte - MG, 2006a.

Políticas públicas e ampliação de capital social em comunidades segregadas: o programa Santo André Mais Igual. Dissertação de Mestrado apresentada ao Departamento de Ciência Política da Faculdade de Filosofia, Letras e Ciências Humanas - FFLCH /USP, 2006b.

PREFEITURA MUNICIPAL DE CAMPINAS. Escritório de Planejamento da Cidade. Secretaria Municipal de Planejamento, Desenvolvimento Urbano e Meio Ambiente de Campinas. $1^{o}$ Encontro Internacional a Metrópole e o Futuro - 
Reconhecendo e Planejando Campinas. Cd-rom do encontro contendo matriz de periodização da cidade. Campinas, 2004.

PRÉTECEILLE, Edmond. "A construção social da segregação urbana: convergências e divergências". In: Revista Espaço \& Debates, no. 45, São Paulo, Núcleo de Estudos Regionais e Urbanos - NERU, 2004.

ROLNIK, Raquel. A cidade e a lei: legislação, política urbana e territórios na cidade de São Paulo. São Paulo: Studio Nobel: Fapesp, 1999.

SABATINI, Francisco; CÁCERES, Gonzalo \& CERDA, Jorge. "Segregação residencial nas principais cidades chilenas: tendências das três últimas décadas e possíveis cursos de ação". Espaço \& Debates - Segregações Urbanas, no. 45, São Paulo, Núcleo de Estudos Regionais e Urbanos NERU, 2004.

SABATINI, Francisco. "Medición de la segregación residencial: reflexiones metodológicas desde la ciudad latinomamericana". In: CÁCERES, G. \& SABATINI, F (eds.). Barrios cerrados em Santiago do Chile - Entre la exclusión y la integración residencial. Santiago: Instituto de Geografia, PUC Chile, 2004.

SCOTT, John. Social network analysis: a handbook. Newbury Park, California: Sage Publications, 2000.

TOLEDO, Demétrio. Redes empresariais e ação coletiva: FIESP e CIENSP, 19922004. Dissertação de mestrado apresentada ao departamento de Sociologia da Faculdade de Filosofia, Letras e Ciências Humanas - FFLCH /USP, 2005.

TORRES, Haroldo da Gama; MARQUES, Eduardo; FERREIRA, Maria Paula e BITAR, Sandra. "Pobreza e espaço: padrões de segregação em São Paulo". Estudos Avançados. IEA, v. 17, nº 47, jan./abr. 2003.

TORRES, Haroldo da Gama. "Segregação residencial e políticas públicas: São Paulo na década de 1990". Revista Brasileira de Ciências Sociais, n. 54, 2004.

VILLAÇA, Flávio. "Efeitos do espaço sobre o social na metrópole brasileira". In: SOUZA, M. A. (ed.). Metrópole e globalização: conhecendo a cidade de São Paulo. São Paulo, Cedesp, 1999.

WHITE, Harrison. "Network switchings and bayesian forks: reconstructing the social and behavioral sciences". In: Social Research: An international quaterly of the social sciences. Vol 62, No 4, 1995.

ZALUAR, Alba. A máquina e a revolta. São Paulo: Ed. Brasiliense, 1985.

ZIMMERMANN, G. “O Município o sistema tributário: os municípios paulistas e o caso de Campinas”. In: A interiorização do desenvolvimento econômico no 
Estado de São Paulo (1920-1980), Fundação SEADE, São Paulo, v.1, n. 3, 1989.

\section{MATÉRIAS DE IMPRENSA}

DIÁRIO DO POVO. "Será inaugurada dia 5 a Vila Castelo Branco. Campinas, 1.8.1967”. 